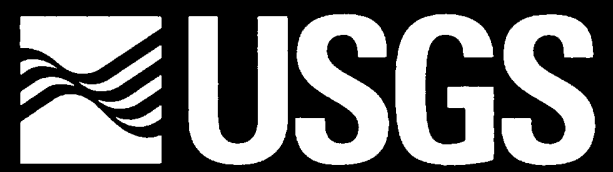

science for a changing world

Prepared in cooperation with the CITY OF OMAHA and the

PAPIO-MISSOURI RIVER NATURAL RESOURCES DISTRICT

\title{
QUANTITY AND QUALITY OF URBAN STORMWATER RUNOFF FROM SELECTED DRAINAGE BASINS, OMAHA, NEBRASKA, 1992-93
}

Water-Resources Investigations Report 98-4168 
U.S. Department of the Interior

U.S. Geological Survey

QUANTITY AND QUALITY OF URBAN STORMWATER RUNOFF FROM SELECTED

DRAINAGE BASINS, OMAHA, NEBRASKA, 1992-93

By Abraham H. Chen and Francis J. Jelinek

Water-Resources Investigations Report 98-4168

Prepared in cooperation with the

CITY OF OMAHA and the

PAPIO-MISSOURI RIVER NATURAL RESOURCES DISTRICT 


\section{U.S. DEPARTMENT OF THE INTERIOR}

Bruce Babbitt, Secretary

\section{U.S. GEOLOGICAL SURVEY \\ Charles G. Groat, Director}

Any use of trade, product, or firm names in this publication is for descriptive purposes only and does not imply endorsement by the U.S. Government.

Lincoln, Nebraska, 1999

For additional information write to:

District Chief

U.S. Geological Survey, WRD

406 Federal Building

100 Centennial Mall North

Lincoln, NE 68506

Copies of this report can be purchased from:

U.S. Geological Survey

Information Services

Box 25286

Denver, CO 80225 


\section{CONTENTS}

\begin{tabular}{|c|}
\hline \multirow{2}{*}{ Introduction } \\
\hline \\
\hline Description of Study Area \\
\hline Methods \\
\hline Site Selection \\
\hline Instrumentation and Data Collection \\
\hline 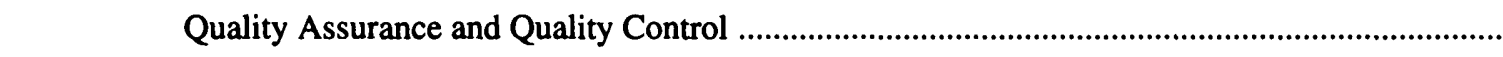 \\
\hline Acknowledgments \\
\hline Characterization of Stormwater \\
\hline Storm Characteristics \\
\hline Stormwater Quality \\
\hline 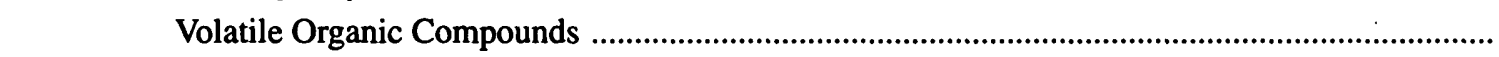 \\
\hline 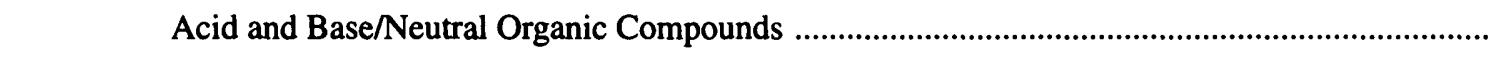 \\
\hline 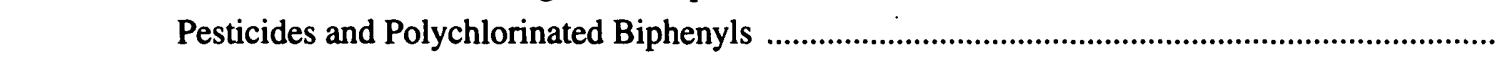 \\
\hline 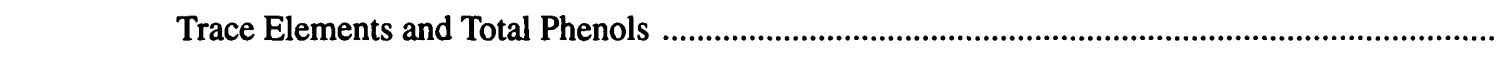 \\
\hline Oxygen Demand, Properties, and Bacteria \\
\hline Nutrients \\
\hline Oil and Grease \\
\hline Major Ions, Field Measurements, and Total Organic Carbon \\
\hline Estimated Constituent Transport \\
\hline Direct Method for Estimating Single-Storm Constituent Loads \\
\hline Simple Method for Estimating Annual Constituent Loads \\
\hline 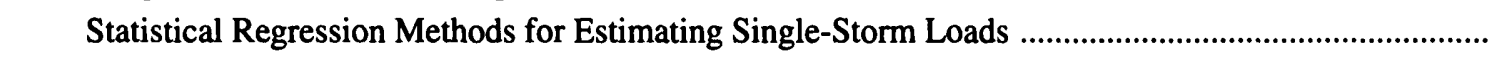 \\
\hline 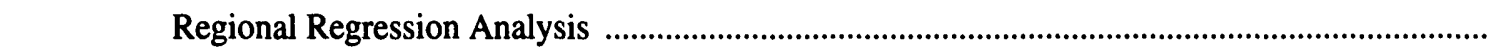 \\
\hline Local Regression Analysis \\
\hline Adjusted Regional Regression Equations \\
\hline \\
\hline \\
\hline
\end{tabular}

\section{APPENDIXES}

A-Storm rainfall and runoff characteristics for five sites, Omaha, Nebraska, 1992-93 ....................... A-1

B-Water-quality data collected from five sites, Omaha, Nebraska, 1992-93 ..................................... B-1

C-Quality assurance information summary ....................................................................................... C-1 


\section{CONTENTS--Continued}

\section{FIGURES}

1. Map showing location of study area, Omaha, Nebraska.........................................................................

2. Map showing location of monitoring sites and their discharge basins, Omaha, Nebraska.................... 5

3. Diagrams showing observed and predicted loads of dissolved solids and total ammonia plus

organic nitrogen as nitrogen in stormwater runoff, Omaha, Nebraska, 1992-93.

\section{TABLES}

1. Characteristics of stormwater-runoff monitoring sites and basins, Omaha, Nebraska

2. Storm rainfall and runoff characteristics for five sites, Omaha, Nebraska, 1992-93 (Appendix A)

3. Constituents and properties and detection limits in water samples collected at the five monitoring sites from six stormwater-runoff events, Omaha, Nebraska, 1992-93 (Appendix B)

4. Concentrations of volatile organic compounds in stormwater-runoff in grab samples from five sites, Omaha, Nebraska, 1992-93 (Appendix B).

5. Concentrations of base/neutral organic compounds in stormwater-runoff flow-weighted composite samples collected from five sites, Omaha, Nebraska, 1992-93 (Appendix B) .........

6. Concentrations of pesticides and polychlorinated biphenyls in stormwater-runoff flow-weighted composite samples collected from five sites, Omaha, Nebraska, 1992-93 (Appendix B)...

7. Concentrations of trace elements in stormwater-runoff in flow-weighted composite samples and total phenols in stormwater-runoff grab samples collected from five sites, Omaha, Nebraska, 1992-93 (Appendix B)

8. Concentrations of constituents and properties in stormwater-runoff in flow-weighted composite and grab samples collected from five sites, Omaha, Nebraska, 1992-93 (Appendix B).

9. Major ions, properties, and total organic carbon in flow-weighted stormwater-runoff samples from five sites, Omaha, Nebraska, 1992-93 (Appendix B)

10. Summary of results of duplicate analyses for stormwater-runoff samples, Omaha, Nebraska, 1992-93 (Appendix C)

11. Summary of results of field-blank analyses for stormwater-runoff samples, Omaha, Nebraska, 1992-93 (Appendix C)

12. Summary of results of field-spike analyses for stormwater-runoff samples, Omaha, Nebraska, 1992-93 (Appendix C)

13. Summary of storm characteristics for the three land-use types, Omaha, Nebraska, 1992-93

14. Statistical summary of constituents and properties in stormwater-runoff samples for the residential land-use basins, sites 1 and 4, Omaha, Nebraska, 1992-93 


\section{CONTENTS--Continued}

15. Statistical summary of constituents and properties in stormwater-runoff samples for the two commercial land-use basins, sites 2 and 5, Omaha, Nebraska, 1992-93

16. Statistical summary of constituents and properties in stormwater-runoff samples for the industrial land-use basin, site 3, Omaha, Nebraska, 1992-93

17. Stormwater loads per event for 12 constituents at five monitoring sites as calculated by the direct method

18. Mean and median concentrations of 12 constituents in samples collected during storms for residential, commercial, and industrial land-use basins, Omaha, Nebraska, 1992-93

19. Estimated annual constituent loads as determined by the U.S. Environmental Protection Agency simple method using data from the five sites, Omaha, Nebraska, 1992-93

20. Coefficients for three variable linear regression models for stormwater-runoff loads for Region II

21. Summary of coefficients for local regression models forr stormwater-runoff loads for drainage basins, Omaha, Nebraska, 1992-93

22. Coefficients for the MAP-R-P $+\mathbf{n V}$ adjusted regression models for stormwater-runoff loads and volumes at monitored/unmonitored basins, Omaha, Nebraska, 1992-93

23. Estimated stormwater-runoff event loads and volumes for five monitoring sites using adjusted regional regression models, Omaha, Nebraska, 1992-93

24. Storm statistics for Omaha, Nebraska

25. Mean monthly and annual estimated stormwater-runoff loads and volumes for a residential basin (site 1) using adjusted regional regression models, Omaha, Nebraska, 1992-93

26. Estimated annual loads for five monitoring sites using adjusted regional regression models, Omaha, Nebraska, 1992-93 


\section{CONTENTS--Continued}

CONVERSION FACTORS AND VERTICAL DATUM

\begin{tabular}{rll}
\hline Multiply & \multicolumn{1}{c}{ By } & To obtain \\
\hline foot $(\mathrm{ft})$ & 0.3048 & meter \\
mile $(\mathrm{mi})$ & 1.609 & kilometer \\
acre & 0.004047 & square kilometer \\
square foot $\left(\mathrm{ft}^{2}\right)$ & 929.0 & square centimeter \\
gallon $(\mathrm{gal})$ & 10.003785 & cubic meter \\
cubic foot $\left(\mathrm{ft}^{3}\right)$ & 0.02832 & cubic meter \\
cubic foot per second $\left(\mathrm{ft}^{3} / \mathrm{s}\right)$ & 0.02832 & cubic meter per second \\
gallon per minute $(\mathrm{gal} / \mathrm{min})$ & 0.06309 & liter per second \\
gallon per day $(\mathrm{gal} / \mathrm{d})$ & 0.003785 & cubic meter per day \\
\hline
\end{tabular}

Temperature in degrees Celsius $\left({ }^{\circ} \mathrm{C}\right)$ may be converted to degrees Fahrenheit $\left({ }^{\circ} \mathrm{F}\right)$ as follows:

$$
{ }^{\circ} \mathrm{F}=\left(1.8 \times{ }^{\circ} \mathrm{C}\right)+32
$$

Temperature in degrees Fahrenheit $\left({ }^{\circ} \mathrm{F}\right)$ may be converted to degrees Celsius $\left({ }^{\circ} \mathrm{C}\right)$ as follows:

$$
{ }^{\circ} \mathrm{C}=\left({ }^{\circ} \mathrm{F}-32\right) / 1.8
$$

Sea level: In this report, "sea level" refers to the National Geodetic Vertical Datum of 1929 (NGVD of 1929)-a geodetic datum derived from a general adjustment of the first-order level nets of both the United States and Canada, formerly called Sea Level Datum of 1929.

Specific conductance is given in microsiemens per centimeter at 25 degrees Celsius $\left(\mu \mathrm{S} / \mathrm{cm}\right.$ at $\left.25^{\circ} \mathrm{C}\right)$. 


\title{
QUANTITY AND QUALITY OF URBAN STORMWATER RUNOFF FROM SELECTED DRAINAGE BASINS, OMAHA, NEBRASKA, 1992-93
}

\author{
By Abraham H. Chen and Francis J. Jelinek
}

\section{ABSTRACT}

The U.S. Geological Survey, in cooperation with the City of Omaha and the Papio-Missouri River Natural Resources District, Nebraska, conducted a study to describe stormwater-runoff quantity and quality from selected basins in Omaha. The study was done to meet technical data requirements for the City of Omaha to obtain a National Pollutant Discharge Elimination System Permit from the U.S. Environmental Protection Agency.

Stormwater-runoff quantity and quality from five sites located in residential, commercial, and industrial land-use basins were monitored from May to November 1992 and April through August 1993. Sites 1 and 4 were representative of residential land use; sites 2 and 5 were representative of commercial land use; and site 3 was representative of industrial land use.

Total rainfall, runoff volume, runoff-rainfall ratio, peak discharge, rainfall and runoff duration, and number of dry hours between storms were calculated and compiled. Mean rainfall during the study was slightly greater in the residential basins ( 0.60 inch) than in the commercial ( 0.45 inch) and industrial ( 0.46 inch) basins. However, mean runoffrainfall ratio for the industrial $(0.32)$ and commercial $(0.38)$ basins was more than twice the runoff-rainfall ratio of the residential basins $(0.15)$.

Grab samples and flow-weighted composite samples were collected at each of the five sites during six storms and were analyzed for 147 chemical, physical, and biological characteristics. Grab samples, collected within the first 30 minutes of each storm, represented the storm's first-flush effects, and were analyzed for $\mathrm{pH}$, water temperature, residual chlorine, volatile organic compounds, cyanide, total phenols, biological oxygen demand, fecal coliform and fecal streptococcus bacteria, and oil and grease. Flowweighted samples were composited during the first 3 hours of a storm and were analyzed for acid and base/neutral organic compounds, pesticides and polychlorinated biphenyls, trace elements, chemical oxygen demand, suspended solids, dissolved solids, nutrients, major ions, alkalinity, $\mathrm{pH}$, specific conductance, and total organic carbon.

The volatile organic compounds-chloroform, dichlorobromomethane, methyl chloride, and toluene-were detected in concentrations ranging from 0.4 to 7.0 micrograms per liter. Toluene was detected only in the residential basins. Eleven base/neutral compounds with concentrations ranging from 9 to 150 micrograms per liter were detected in a commercial basin (site 5) during a storm-runoff event May 22, 1993. Eleven of 12 base/neutral compounds sampled for were detected at five sites. Concentrations of six of the compounds exceeded U.S. Environmental Protection Agency (USEPA) Maximum Contaminant Levels (MCLs) for drinking water.

No pesticide or polychlorinated biphenyl concentrations exceeded MCLs. The trace elements-total beryllium and total lead-exceeded MCLs for drinking water. Total lead also exceeded treatment action levels established by the USEPA for drinking water. Median concentrations of lead from the industrial basin were about 6 times greater than in the residential and commercial basins. Median concentrations of total copper, total nickel, and total zinc were about 3 times greater in samples collected from the industrial basin than from the residential and commercial basins. 
Stormwater-runoff constituent loads for 12 constituents were estimated using three methods. The 12 constituents were biochemical oxygen demand, chemical oxygen demand, suspended solids, dissolved solids, total nitrogen as nitrogen $(\mathrm{N})$, total ammonia plus organic nitrogen as $\mathrm{N}$, total phosphorus, dissolved phosphorus, total cadmium, total copper, total lead, and total zinc. The first method used was direct computation of observed data. The second method used was the USEPA simple method for calculating annual pollutant loads. The third method used was a statistical regression method, adjusting the regional models by using local monitoring data. The regression models estimated stormwater-runoff constituent loads.

\section{INTRODUCTION}

Section 402 of the Water Quality Act of 1987 requires municipalities with populations of 100,000 or greater to obtain permits to discharge urban stormwater to receiving streams. Final regulations for a National Pollutant Discharge Elimination System (NPDES) were published by the U.S. Environmental Protection Agency (USEPA) in November 1990 (U.S. Environmental Protection Agency, 1990) that required cities to provide, as part of the permit application, the following technical data:

1. Characterization of the quantity and quality of water from storm-sewer outfalls during dry periods when flows are not a result of storm runoff, but are primarily seepage from shallow ground water and return flows from urban water uses that are not part of the sanitary sewer system,

2. Characterization of the quality of water in bodies receiving stormwater-runoff discharges and the impact of pollutants from these discharges on the receiving body, based on existing data,

3. Characterization of meteorological conditions (rainfall), based on existing data,

4. Characterization of the quantity and quality of discharge from 5 to 10 representative outfalls during six representative storm events, and

5. Determination of annual and seasonal pollutant loads from each storm-sewer outfall in the reporting area.
The U.S. Geological Survey (USGS), in cooperation with the City of Omaha and the PapioMissouri River Natural Resources District, conducted a study describing the quantity and quality of stormwater discharges from selected storm sewers draining areas representative of the various urban land uses in Omaha, Nebraska. The NPDES permit applications require the city to characterize the stormwater discharges from separate municipal storm-sewer systems. This effort primarily was intended to address item 4 of the technical data requirements previously described for a stormwater discharge permit.

\section{Purpose and Scope}

This report describes the results of the USGS stormwater data collection and analysis work in Omaha, Nebraska, to meet technical data needs for item 4 of the NPDES permitting requirements. Site selection and the sampling strategy for documenting the stormwater discharges from five urban basins in Omaha are included in the report. Storm characteristics and water-quality data collected at the five sites from May to November 1992 and from April through August 1993 also are provided. A statistical summary of the concentrations of an extensive list of water-quality constituents detected in the storm water discharged from the five basins shows the type and relative significance of contaminants that might be expected from urban storm sewers in the Omaha metropolitan area. Finally, the mass transport of loads for selected constituents in the five basins is presented based on three methods: the direct method, the USEPA simple method, and a statistical method. Two methods were used to estimate the transport by individual storms, and one method was used to estimate the annual load from each urban basin.

\section{Description of Study Area}

The City of Omaha, the largest city and principal industrial center in Nebraska, is located in the eastern part of the State (fig. 1) and has a population in excess of 350,000 . Within Omaha, approximately 1,725 miles of sewer lines are used for the collection of stormwater and sanitary waste. About one third of this total is combined stormwater and sanitary waste sewers in the Missouri River and Little Papillion Creek watersheds east of 72nd Street. A study area 


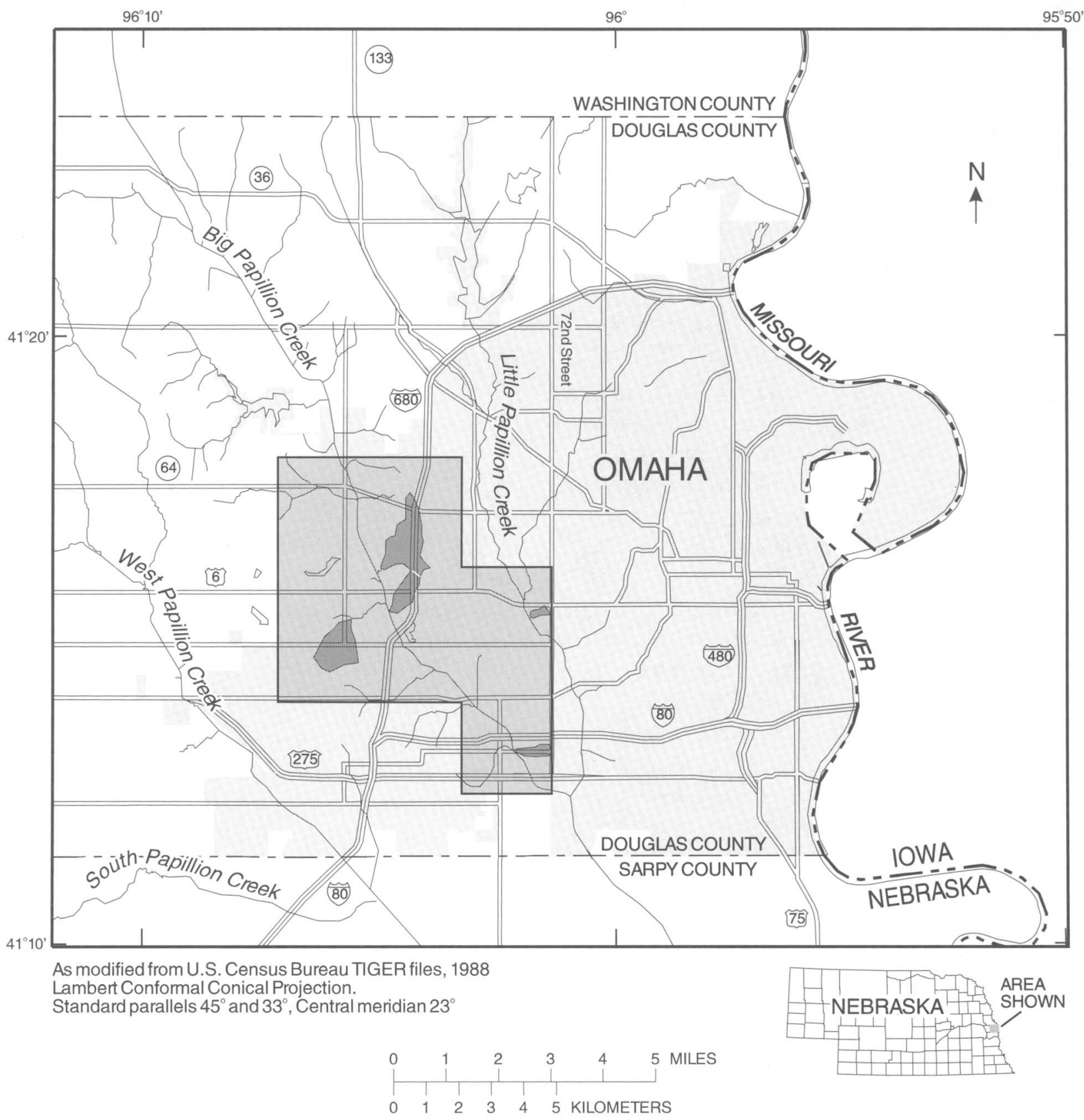

EXPLANATION

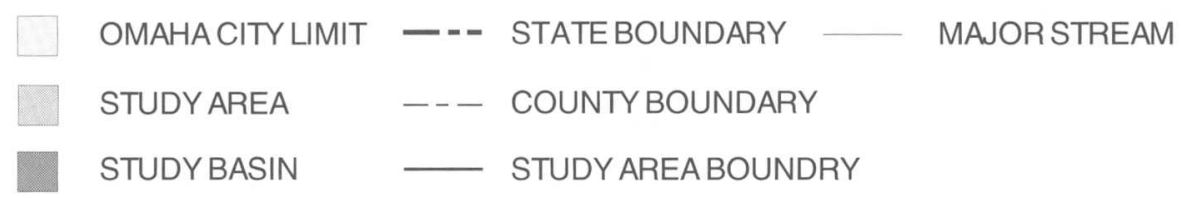

Figure 1. Location of study area, Omaha, Nebraska. 
was delineated to include selected basins representing major types of land-use activities (residential, commercial, and industrial).

The natural landscape of the study area consists of a loess-mottled, upland glacial-till surface of Quaternary age. Locally, the land surface is eroded, accentuating topographically high areas. The loess-covered hills have average basin slopes ranging from 1 to 3 percent. Bedrock of Pennsylvanian age underlies the glacial till in the study area. About 2,000 feet of unexposed sedimentary rock of Pennsylvanian age overlies igneous and metamorphic rocks of Precambrian age (Miller, 1964).

Weather in the study area is highly variable. Extreme changes in temperature are typical, especially during the winter months. The maximum temperature is greater than or equal to $90^{\circ} \mathrm{F}$ about 40 days per year, and the minimum temperature is less than or equal to $32^{\circ} \mathrm{F}$ about 136 days per year. Normal precipitation (rainfall) ranges from 28 to 30 inches annually. About 75 percent of the precipitation occurs from April to September. Intense storms are common, particularly during the spring and early summer. The annual mean relative humidity is approximately 70 percent. Snowfall averages about 30 inches per year. Prevailing winds typically are from the northwest during the winter months and from the south and southeast during summer months (City of Omaha, 1992).

\section{Methods}

Collection of hydrologic data during storms for the purpose of meeting Federal regulations requires specialized procedures (U.S. Environmental Protection Agency, 1990; 1992a; and 1992b). The following sections provide a description of the site selection and sampling strategy, instrumentation and data collection, and quality assurance and qualitycontrol procedures used for this study.

\section{Site Selection}

Five basins were selected in the study area for monitoring stormwater runoff (fig. 2). Each basin drained at least one of the major types of urban land use typical of the Omaha urban landscape-singledwelling (site 1) and multiple-dwelling (site 4) residential, commercial (sites 2 and 5), and industrial (site 3). Major basin characteristics of stormwater runoff monitoring sites are described in table 1. Basin and site selection were based on specific criteria:
1. Relatively homogeneous land use; if possible, only one major land use dominant.

2. A minimum of 70 percent of the land developed to minimize effects of substantial construction activity during the period of data collection.

\section{A maximum of 500 acres in size.}

4. Suitable site for equipment shelter and stormdrain access.

Monitoring sites were located in an area of the city containing storm sewer systems separate from sanitary systems, generally west of 72nd Street, to avoid sampling mixed sanitary and storm sewer discharges. All sampling sites were within a 5-mile radius for effective field-sampling operations during and after storm events (fig. 2). Intense storms during the spring and early summer result in large runoff of short duration. Stormwater runoff in the study area drains into Little Papillion Creek or Big Papillion Creek and its tributaries, both of which drain into the Missouri River (fig. 1). Sampling sites in each basin were selected for the collection of rainfall, stormwater discharges, and stormwater-quality data. A suitable site selected for reliable and credible data required a straight, uniform pipe slope at least six pipe diameters upstream from the flow-measuring device, a location an adequate distance from upstream inflows to allow complete mixing of effluents, and a location unaffected by backwater.

\section{Instrumentation and Data Collection}

To meet stormwater data-collection requirements, instrumentation was installed at each site to monitor rainfall and runoff discharge, and to collect a first-flush sample (grab sample) as well as flowweighted composite samples. Monitoring equipment at each site consisted of a rain gage, stage recorder, automatic water sampler, solar panel and ancillary plumbing, electrical equipment, and shelter to make the site functional and weatherproof. The rain gage recorded on-site measurements of rainfall in 0.01 -inch increments. Water levels or pipe pressures in the storm sewers were recorded in 5-minute increments, and discharges and flow volumes were computed on-site using Manning's equation (Grant, 1991) by a data processor. The automatic water sampler was activated each time a specified volume of water was measured flowing through the storm 


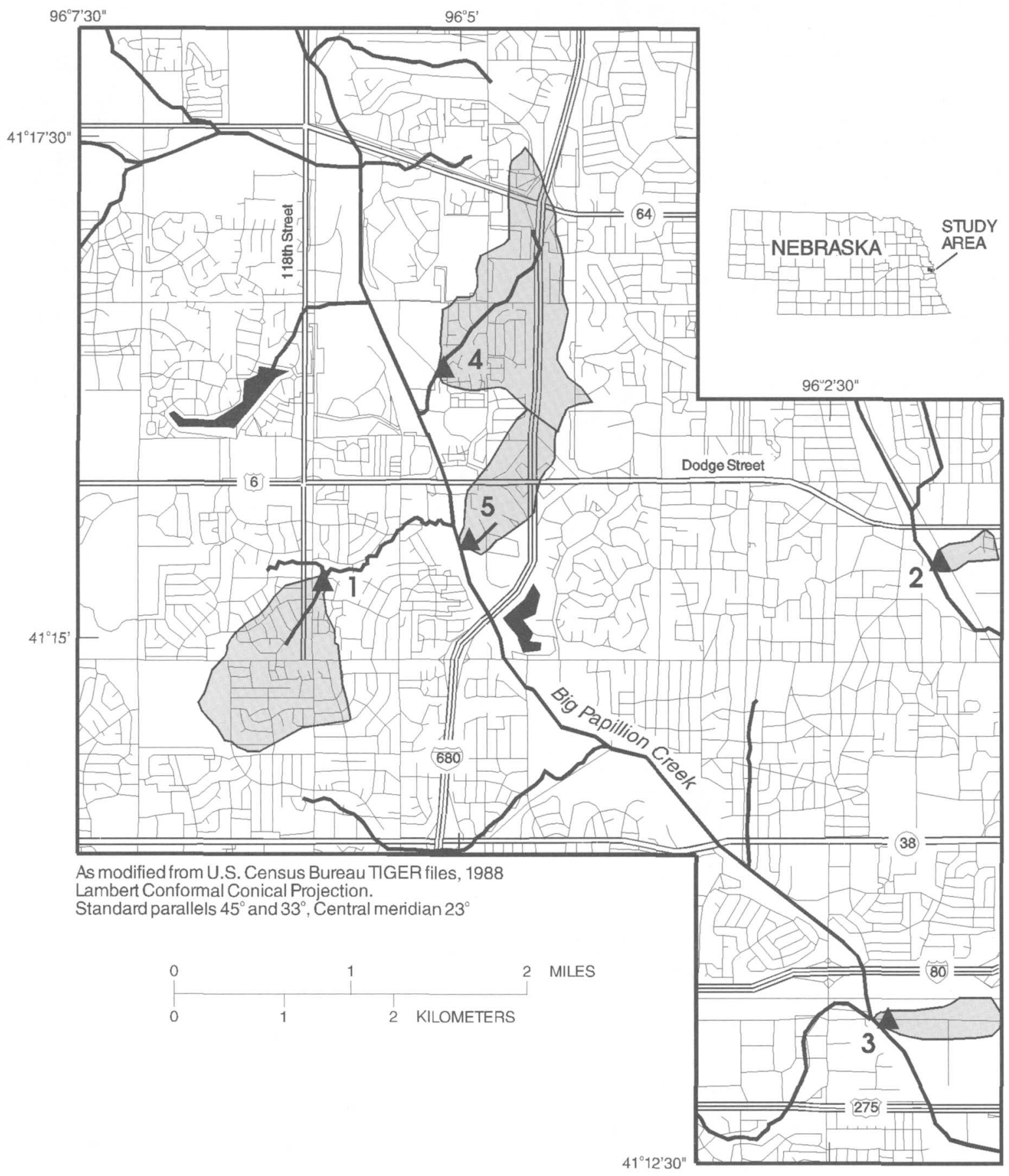

\section{EXPLANATION}

\section{DRAINAGEBASINOF \\ MONITORING SITE \\ 1 MONITORING SITE \\ MAJORSTREAM}

Figure 2. Location of monitoring sites and their discharge basins, Omaha, Nebraska. 
Table 1. Characteristics of stormwater-runoff monitoring sites and basins, Omaha, Nebraska

[See figure 2 for site locations]

\begin{tabular}{|c|c|c|c|c|c|}
\hline $\begin{array}{l}\text { Basin or site } \\
\text { characteristic }\end{array}$ & Site 1 & Site 2 & Site 3 & Site 4 & Site 5 \\
\hline \multicolumn{6}{|l|}{ Contributing drainage area } \\
\hline Square miles & 0.53 & 0.05 & 0.16 & 0.70 & 0.20 \\
\hline Acres & 339 & 32 & 101 & 446 & 129 \\
\hline \multicolumn{6}{|c|}{ Land use (percentage of drainage area) } \\
\hline Residential & 82 & 0 & 0 & 60 & 0 \\
\hline Commercial & 18 & 100 & 0 & 10 & 100 \\
\hline Industrial & 0 & 0 & 100 & 0 & 0 \\
\hline Idle or vacant & 0 & 0 & 0 & 30 & 0 \\
\hline Dominant land use & $\begin{array}{l}\text { Single-dwelling } \\
\text { residential }\end{array}$ & Commercial & Industrial & $\begin{array}{l}\text { Multiple-dwelling } \\
\text { residential }\end{array}$ & Commercial \\
\hline $\begin{array}{l}\text { Impervious area (percent- } \\
\text { age of drainage area) }\end{array}$ & 32 & 65 & 75 & 36 & 65 \\
\hline $\begin{array}{l}\text { Average basin slope } \\
\text { (percent) }\end{array}$ & 2.7 & 2.0 & 1.3 & 2.4 & 2.6 \\
\hline \multicolumn{6}{|l|}{ Stormwater outfall } \\
\hline Pipe diameter (inches) & 96 & 48 & 78 & Open channel ${ }^{1}$ & 60 \\
\hline Slope (percent) & .75 & .52 & .40 & .21 & 1.0 \\
\hline Roughness coefficient $^{2}$ & .016 & .016 & .017 & .035 & .016 \\
\hline
\end{tabular}

sewer. The sampler pumped water from the storm sewer through Teflon tubing into glass sample bottles inside the sampler. Sample bottles filled during the storm were retrieved after the storm. Instruments at the site recorded the incremental rainfall, continuous stage, discharge computations, and the number of times samples were collected.

Six storm events were documented at each site from May to November 1992 and April through August 1993. The following three general guidelines, provided by the USEPA (1992a) for selection of storms to be documented, were used to decide which storms to sample. Departures from these guidelines occurred when field conditions and operational limitations prevented the guidelines from being met or might have prevented the sampling of six storm events.
1. The storm should be preceded by at least 72 hours of dry weather,

2. Precipitation over the entire basin must be greater than 0.1 inch, and

3. Where feasible, the storm rainfall should not vary by more than 50 percent from the average storm rainfall volume and duration.

Storm characteristics were determined for each storm event recorded. Information included in appendix $\mathrm{A}$, table 2 provides characteristics of storm-runoff events that have been found to be related to the transport of contaminants and have been used in conjunction with water-quality data to estimate transport of selected contaminants from urban landscapes. These characteristics include total rainfall, runoff volume, runoff-rainfall ratio, peak discharge, rainfall and runoff dura- 
tion, and number of dry hours between storms. Missing rainfall values at some sites were replaced by data from the nearest site (for example, site 5 data was used for missing data at site 1). Runoff volumes for each storm were computed by accumulating the instantaneous discharges recorded at each site. The runoff-rainfall ratio is determined by dividing the runoff volume by the rainfall total. Rainfall duration is the time from the first 0.01 inch to the last 0.01 inch of rainfall. The time since previous storm (dry hours) is the approximate time between the last 0.01 inch of rainfall of the previous storm to the first 0.01 inch of rainfall of the next storm.

Stormwater samples were collected and analyzed for 147 constituents and properties for each storm recorded at the five sampling sites and were tabulated according to NPDES guidance (U.S. Environmental Protection Agency, 1992a). Of the 147 constituents and properties, 135 were pollutants or naturally occurring constituents that could be considered pollutants if concentrations were sufficiently large. The 147 constituents and properties required for analysis and their analytical detection limits are listed in appendix B, table 3. Concentrations of constituents detected for each site also are listed in appendix B and include: volatile organic compounds (VOCs) (table 4), base/neutral organic compounds (table 5), pesticides and polychlorinated biphenyls (PCBs) (table 6), trace elements and total phenols (table 7), constituents or properties (table 8), and major ions, properties, and total organic carbon (table 9). Each sample set consisted of a grab sample and flow-weighted composite samples.

A single grab sample was collected during the first 30 minutes of a runoff event from each storm and represented the storm's first-flush effects. This sample was used to make on-site measurements of $\mathrm{pH}$, water temperature, and residual chlorine.

Because the presence of residual chlorine in grab samples might cause degradation of organic contaminants after sample collection, field test kits were used to detect the residual chlorine in these samples. If residual chlorine was detected, then samples collected for VOC and biochemical oxygen demand (BOD) analysis were treated with sodium thiosulfate to preserve sample integrity in accordance with the NPDES sampling protocol. The sample also was used for laboratory analysis for VOCs, cyanide, total phenols, BOD, fecal coliform and fecal streptococcus bacteria, and oil and grease. Samples were retrieved, using grab-sampling techniques, and processed within 3 hours after collection because the constituents have a tendency to volatilize or degrade with time.

Flow-weighted samples collected by the automatic sampler during the first 3 hours of a runoff event were composited into one sample. Composite samples consisted of a minimum of three discrete aliquots per hour from the stormwater discharge using the automatic samplers. These flow-weighted composite samples were analyzed in the laboratory for acid and base/neutral organic compounds, pesticides and PCBs, trace elements, chemical oxygen demand (COD), suspended solids, dissolved solids, nutrients, major ions, alkalinity, $\mathrm{pH}$, specific conductance, and total organic carbon.

Water-quality samples were collected, preserved, and shipped (Ward and Harr, 1990), in accordance with applicable USGS protocols and the USEPA sampling Protocols (U.S. Environmental Protection Agency, 1990 and 1992a) to the USGS National Water Quality Laboratory (NWQL) in Arvada, Colorado, for analysis. Some constituents, such as selected trace elements and nutrients, were analyzed as total concentrations that included both dissolved and particulate concentrations. Total concentrations of antimony, cyanide, silver, and thallium were determined at the Rocky Mountain Analytical Laboratory in Denver, Colorado; BOD samples were analyzed by HWS Technologies, Inc., in Lincoln, Nebraska; fecal coliform and fecal streptococcus bacteria counts were determined at the USGS Nebraska District Laboratory, in Lincoln, Nebraska; and the remainder of the analyses were determined at the USGS NWQL in Arvada, Colorado.

\section{Quality Assurance and Quality Control}

Quality-assurance and quality-control protocols were used during this study to ensure the accuracy of the data collected and to assist in the interpretation of collected data. Quality-control samples were collected to assess the adequacy of the general water-quality sampling and analysis procedures and to identify factors that might have produced discrepancies in the data.

Quality assurance refers to proper office, field, and laboratory procedures. Field quality-assurance practices involved calibration of all field meters and probes, and cleaning of sampling equipment prior to all site visits. Immediately prior to each sampling, meters and probes were recalibrated. Because water 
is electrically neutral (the sum of cations equals the sum of the anions), the percent difference between the sum of the cations and the sum of the anions helps determine if the analytical results are accurate. The balance of cations and anions, in milliequivalents per liter (meq/L), was used to ensure internal consistency of analytical results. Analytical results were compared within each sample set or with previous results for each site and with other study sites to detect possible inconsistencies. If inconsistencies were detected, checks for transcribing errors were conducted at the NWQL, and analytical reruns were requested on the remaining sample.

Quality-control samples for 107 of 147 chemical constituents were submitted to the NWQL on one or more occasions for duplicate, field-blank, and field-spike analyses. Analysis of duplicate samples was intended to identify precision associated with sample collection, shipping and storage, as well as laboratory analytical methods. Analysis of fieldblank and field-spike samples was used as a means of estimating the accuracy of the analytical methods. The results of duplicate, field-blank, and field-spike analyses are presented in appendix C, tables 10,11 , and 12. Quality control of all analyses conducted for any constituent at the NWQL consists of reference materials from the USEPA and the National Bureau of Standards, spiked samples, and samples split between different laboratories (Fishman and Friedman, 1989).

A summary of differences in concentrations between primary- and duplicate-sample pairs for 38 constituents analyzed is included in appendix $\mathrm{C}$, table 10. In general, the duplicate analyses for pesticides, trace elements, major ions, and nutrients implies that sample preparation and analytical methods were within acceptable limits, with the exception of arsenic. Concentrations of arsenic showed a 67 percent difference between the original and duplicate samples. The percent difference for replicate samples of arsenic is misleading because concentrations are so small. Small differences of even $1 \mu \mathrm{g} / \mathrm{L}$ (micrograms per liter) between concentrations can result in large percent differences.

Field blanks, in which organic-free water was used as a water sample, were exposed to all aspects of sample collection and processing equipment, preservation and transportation procedures, and laboratory handling. Chemical analysis of this water was designed to determine the adequacy of the process of equipment cleaning between sampled sites, or to quantify carryover of any chemical contamination between sites. The blanks were tested for VOCs, carbaryl pesticides, trace elements, nutrients, and major ions to determine if contamination was introduced. Results of the analyses of the fieldblank samples (appendix C, table 11) show that small concentrations of methylene chloride, arsenic, lead, six major ions, and dissolved and total phosphorus were detected in the field blanks. No residues were detected in the field blanks for any other constituent.

Field-spike samples are collected from a stream and have commercially prepared mixtures of known concentration added to the samples. Field samples were collected and spiked with mixtures of known concentrations of acid and base/neutral compounds and selected organochlorine pesticides. They were submitted to the NWQL for laboratory analysis on two occasions. The results of the analyses were expressed as the recoveries of each constituent in percent (appendix C, table 12). Acceptable ranges of recoveries are 60-140 percent for acid organic compounds, 70-130 percent for base/neutral organic compounds, and 50-140 percent for organochlorine pesticides (Franson, 1989, p. 1-8). Most of the recoveries for acid and base/neutral compounds were within these ranges. The recoveries for common pesticides, such as 4,4 ' -DDT, 4,4 ' -DDE, and 4,4 ' -DDD, were within the acceptable range. Ranges of recovery for eight pesticides were greater than 170 percent; however, these compounds were not present in stream samples collected without commercially prepared mixtures added.

\section{Acknowledgments}

The authors appreciate the assistance and cooperation from personnel of the City of Omaha and the Papio-Missouri River Natural Resources District during this study. Special thanks are given to Michael J. Merriex, Kirk R. Pfeffer, and Royal Lewis and his crews, of the Omaha Public Works Department, for their assistance in collecting stormwater samples. 


\section{CHARACTERIZATION OF STORMWATER}

Storm intensity and duration are measurable parts of the precipitation and runoff process that might affect the amount of potential contaminant in a receiving stream. The time between runoff events also might affect the amount of potential contaminant in a receiving stream because contaminants can accumulate with time in a watershed prior to a runoff event. Concentrations of constituents might vary in receiving streams as a result of differences in storm characteristics, as well as differences in land use. Concentrations of constituents determined from single grab samples collected from a stream represent the water-quality conditions at a specific point in time during the storm event. In contrast, samples that result from combining single samples collected during a storm into one composite sample represent the average water quality of a single storm.

\section{Storm Characteristics}

Statistical summary information, provided in table 13, is computed from the information for each storm monitored (appendix A, table 2). Measures of the central tendency of the values and their distribution are included for both parametric and nonparametric methods. Minimum and maximum values define the overall range of the variables, and 25 th and 75 th percentiles define a range of values for a more general examination of the variation (table 13).

Storm characteristics from sites with similar dominating land use in the basin were grouped together into residential, commercial, and industrial land-use (table 13). Mean rainfall was larger in the residential basins ( $0.60 \mathrm{inch}$ ) than in the commercial ( 0.45 inch) or industrial basins ( 0.46 inch). Runoffrainfall ratios are always less than one, which is to be expected, unless some stream discharge reaches the site that is not from rainfall. Ratios are dependent on the physical characteristics of a basin-percent impervious surface, shape, size, and slope, and rainfall amount, intensity, and duration. For example, infiltration and retention of stormwater will decrease the ratio, whereas greater percentage of impervious surface increases the ratio. Commercial and industrial areas that typically have more impervious area and less retention have a runoff-rainfall ratio 2 or more times larger than the residential areas (table 13). Also, the storm drainage systems in the commercial and industrial basins appear to be more direct and probably have more developed channelization than the residential areas. Commercial and industrial basins had a shorter duration of runoff even though the rainfall duration tended to be longer than in the residential basins.

\section{Stormwater Quality}

Statistical summaries of the quality of stormwater by constituent group are presented in tables 14-16. The summaries use descriptive statistics to describe the central tendency and the variability in concentrations of each constituent. Detection limits and their exceedances also are included in the summaries. Separate summaries were made for each major land-use category for comparisons of constituent concentrations among the three types of land use. Thirty-eight of the 147 constituents were detected in water samples from the basins, and 8 constituents exceeded the USEPA's maximum contaminant levels (MCLs) for drinking water at least once.

\section{Volatile Organic Compounds}

Small concentrations of chloroform, dichlorobromomethane, methyl chloride, and toluene were detected in samples collected at one or more sites, except in one of the commercial basins (site 2) (appendix B, table 4). Analytical detection limits are listed in appendix $\mathrm{B}$, table 3 . The largest concentrations of these four compounds were 7.0, 0.4, 0.5, and $2.9 \mu \mathrm{g} / \mathrm{L}$, respectively. Methyl chloride was detected at four of the five sites. Methyl chloride is a commonly used solvent and degreasing compound. One residential basin (site 4) had the most detections of VOCs. Toluene was detected only in the residential basins (sites 1 and 4). Toluene is used for many purposes, including industrial solvents, thinner in nitrocellulose lacquers, and detergents, and is a component of gasoline. Even though VOCs were detected, no concentrations exceeded the MCLs. Also, the 75th percentile did not exceed the detection limit for any VOC in any basin, except for methyl chloride in the residential basins (tables 14-16).

\section{Acid and Base/Neutral Organic Compounds}

Of the 10 acid organic compounds analyzed, none were detected in stormwater-runoff samples (appendix B, table 3). Twelve of 45 base/neutral organic compounds were detected in 45 percent of samples collected in the five basins (appendix B, 
Table 13. Summary of storm characteristics for the three land-use types, Omaha, Nebraska, 1992-93

[See figure 2 for site location; in., inches; min, minute; hrs, hours]

\begin{tabular}{|c|c|c|c|c|c|c|c|c|}
\hline Characteristic & $\begin{array}{c}\text { Number } \\
\text { of } \\
\text { storms }\end{array}$ & Minimum & Mean & Median & Maximum & $\begin{array}{l}\text { 25th per- } \\
\text { centile }\end{array}$ & $\begin{array}{l}\text { 75th per- } \\
\text { centile }\end{array}$ & $\begin{array}{c}\text { Stan- } \\
\text { dard } \\
\text { devia- } \\
\text { tion }\end{array}$ \\
\hline \multicolumn{9}{|c|}{ Residential basins (sites 1 and 4) } \\
\hline Rainfall total (in.) & 133 & 0.03 & 0.60 & 0.41 & 3.06 & 0.16 & 0.84 & 0.59 \\
\hline $\begin{array}{l}\text { Runoff volume, total } \\
\text { (in.) }\end{array}$ & 127 & .00 & .10 & .05 & 1.11 & .01 & .14 & .16 \\
\hline Runoff-rainfall ratio & 127 & .00 & .15 & .13 & .53 & .07 & .21 & .11 \\
\hline $\begin{array}{l}\text { Rainfall duration } \\
\text { (min) }\end{array}$ & 127 & 10 & 335 & 175 & 2,085 & 86 & 447 & 386 \\
\hline $\begin{array}{l}\text { Runoff duration } \\
\text { (min) }\end{array}$ & 127 & 40 & 597 & 480 & 3,600 & 279 & 825 & 520 \\
\hline $\begin{array}{l}\text { Time since previous } \\
\text { storm (hrs) }\end{array}$ & 133 & 8 & 88 & 62 & 592 & 25 & 119 & 98 \\
\hline \multicolumn{9}{|c|}{ Commercial basins (sites 2 and 5) } \\
\hline Rainfall total (in.) & 128 & .01 & .45 & .31 & 2.55 & .12 & .63 & .46 \\
\hline $\begin{array}{l}\text { Runoff volume, total } \\
\text { (in.) }\end{array}$ & 128 & .00 & .20 & .08 & 2.04 & .03 & .24 & .32 \\
\hline Runoff-rainfall ratio & 123 & .01 & .38 & .26 & 1.01 & .11 & .67 & .29 \\
\hline Rainfall duration (min) & 128 & 1 & 164 & 90 & 1,470 & 42 & 192 & 233 \\
\hline Runoff duration (min) & 128 & 30 & 526 & 472 & 2,280 & 241 & 660 & 407 \\
\hline $\begin{array}{l}\text { Time since previous } \\
\text { storm (hrs) }\end{array}$ & 128 & 8 & 91 & 60 & 624 & 28 & 111 & 99 \\
\hline \multicolumn{9}{|c|}{ Industrial basin (site 3) } \\
\hline Rainfall total (in.) & 86 & .02 & .46 & .29 & 2.18 & .12 & .58 & .49 \\
\hline $\begin{array}{l}\text { Runoff volume, total } \\
\text { (in.) }\end{array}$ & 84 & .01 & .17 & .09 & 1.19 & .03 & .24 & .21 \\
\hline Runoff-rainfall ratio & 84 & .05 & .32 & .31 & .95 & .20 & .41 & .17 \\
\hline Rainfall duration (min) & 84 & 5 & 244 & 151 & 1,350 & 74 & 323 & 262 \\
\hline Runoff duration (min) & 84 & 30 & 421 & 345 & 1,980 & 240 & 517 & 302 \\
\hline $\begin{array}{l}\text { Time since previous } \\
\text { storm (hrs) }\end{array}$ & 86 & 6 & 76 & 55 & 525 & 24 & 97 & 79 \\
\hline
\end{tabular}


Table 14. Statistical summary of constituents and properties in stormwater-runoff samples for the residential land-use basins, sites 1 and 4, Omaha, Nebraska, 1992-93

$[\mu \mathrm{g} / \mathrm{L}$, micrograms per liter; $\mu \mathrm{S} / \mathrm{cm}$, microsiemens per centimeter at 25 degrees Celsius; $\mathrm{mg} / \mathrm{L}$, milligrams per liter; cols/100 mL, colonies per $100 \mathrm{milliliters;}$ $\mathrm{NA}$, not applicable; ${ }^{\circ} \mathrm{C}$, degrees Celsius; $<$, less than, based on analytical detection limit (app. B, table 3)]

\begin{tabular}{|c|c|c|c|c|c|c|c|c|}
\hline \multirow[b]{2}{*}{ Constituent or property } & \multirow{2}{*}{$\begin{array}{c}\text { Number } \\
\text { of } \\
\text { samples }\end{array}$} & \multirow{2}{*}{$\begin{array}{l}\text { Number of } \\
\text { detections }\end{array}$} & \multirow[b]{2}{*}{$\begin{array}{l}\text { Percent } \\
\text { detection }\end{array}$} & \multicolumn{5}{|c|}{ Concentration or value } \\
\hline & & & & Minimum & Median & Maximum & $\begin{array}{c}\text { 25th } \\
\text { percentile }\end{array}$ & $\begin{array}{c}\text { 75th } \\
\text { percentile }\end{array}$ \\
\hline \multicolumn{9}{|c|}{ Volatile organic compounds, $\mu \mathrm{g} / \mathrm{L}$} \\
\hline Chloroform & 12 & 3 & 25 & $<0.2$ & $<0.2$ & 7.0 & 0.2 & $<0.2$ \\
\hline Dichlorobromomethane & 12 & 1 & 8 & $<.2$ & $<.2$ & .4 & $<.2$ & $<.2$ \\
\hline Methyl chloride & 12 & 3 & 25 & $<.2$ & $<.2$ & .5 & $<.2$ & .3 \\
\hline Toluene & 12 & 4 & 36 & $<.2$ & $<.2$ & 2.9 & $<.2$ & .2 \\
\hline
\end{tabular}

Anthracene

Benzo-A-anthracene

Benzo-A-pyrene

3,4-Benzofluoranthene

2,4-Benzo(ghi)perylene

Benzo(k)fluoranthene

Bis(2-ethylhexyl)phthalate

Chrysene

Fluoranthene

Indeno(1,2,3-CD)pyrene

Phenanthrene

Pyrene

Chlordane

4,4'-DDT

4,4'-DDE

Diazinon

Carbaryl

2,4-D

PCB-1242

PCB-1254

Arsenic, total

Beryllium, total

Cadmium, total

Chromium, total

Copper, total

Lead, total

Mercury, total

Nickel, total

Zinc, total

Phenols, total
Base/neutral organic compounds, $\mu \mathrm{g} / \mathrm{L}$

$\begin{array}{ll}12 & 0 \\ 12 & 0 \\ 12 & 0 \\ 12 & 0 \\ 12 & 0 \\ 12 & 0 \\ 12 & 4 \\ 12 & 0 \\ 12 & 2 \\ 12 & 0 \\ 12 & 0 \\ 12 & 1\end{array}$

$\begin{array}{rrr}0 & <5 & < \\ 0 & <10 & <10 \\ 0 & <10 & <10 \\ 0 & <10 & <10 \\ 0 & <10 & <10 \\ 0 & <10 & <10 \\ 33 & <5 & < \\ 0 & <10 & <10 \\ 17 & <5 & < \\ 0 & <10 & <10 \\ 0 & <5 & < \\ 8 & <5 & <5\end{array}$

$<5$
$<10$
$<10$
$<10$
$<10$
$<10$
$<5$
$<10$
$<5$
$<10$
$<5$
$<5$

$\begin{array}{rrr}<5 & <5 & <5 \\ <10 & <10 & <10 \\ <10 & <10 & <10 \\ <10 & <10 & <10 \\ <10 & <10 & <10 \\ <10 & <10 & <10 \\ 17 & <5 & 6 \\ <10 & <10 & <10 \\ 7 & <5 & <5 \\ <10 & <10 & <10 \\ <5 & <5 & <5 \\ 6 & <5 & <5\end{array}$

Pesticides and polychlorinated biphenyls, $\mu \mathrm{g} / \mathrm{L}$

10
10
10
2
4
4
10
10

$\begin{array}{rcl}20 & <.1 & <.1 \\ 0 & <.1 & <.1 \\ 0 & <.04 & <.04 \\ 100 & .5 & 1.0 \\ 25 & <.01 & <.01 \\ 100 & .89 & 7.2 \\ 10 & <.1 & <.1 \\ 10 & <.1 & <.1\end{array}$

Trace elements and total phenols, $\mu \mathrm{g} / \mathrm{L}$

$\begin{array}{rrrccc}92 & <1 & 3 & 12 & 2 & 5 \\ 8 & <10 & <10 & 10 & <10 & <10 \\ 0 & <1 & <1 & <1 & <1 & <1 \\ 92 & <1 & 5 & 18 & 3 & 7 \\ 100 & 6 & 8.5 & 20 & 7 & 10.5 \\ 100 & 9 & 13.5 & 28 & 10 & 22 \\ 8 & <.1 & <.1 & .5 & <.1 & <.1 \\ 100 & 3 & 5 & 22 & 3.5 & 9 \\ 100 & 40 & 60 & 120 & 50 & 90 \\ 75 & <1 & 2 & 4 & <1 & 3\end{array}$


Table 14. Statistical summary of constituents and properties in stormwater-runoff samples for the residential land-use basins, sites 1 and 4, Omaha, Nebraska, 1992-93--Continued

\begin{tabular}{|c|c|c|c|c|c|c|c|c|}
\hline \multirow[b]{2}{*}{ Constlituent or property } & \multirow{2}{*}{$\begin{array}{c}\text { Number } \\
\text { of } \\
\text { samples }\end{array}$} & \multirow{2}{*}{$\begin{array}{l}\text { Number of } \\
\text { detectlons }\end{array}$} & \multirow[b]{2}{*}{$\begin{array}{l}\text { Percent } \\
\text { detectlon }\end{array}$} & \multicolumn{5}{|c|}{ Concentration or value } \\
\hline & & & & Minimum. & Median & Maximum & $\begin{array}{c}\text { 25th } \\
\text { percentile }\end{array}$ & $\begin{array}{c}\text { 75th } \\
\text { percentile }\end{array}$ \\
\hline \multicolumn{9}{|c|}{ Oxygen demand, mg/L } \\
\hline Biochemical oxygen demand & 12 & 12 & 100 & 6.8 & 14 & 21 & 12 & 16 \\
\hline Chemical oxygen demand & 12 & 12 & 100 & 33 & 64.5 & 110 & 52 & 70.5 \\
\hline \multicolumn{9}{|c|}{ Physical properties, mg/L } \\
\hline Suspended solids, total & 12 & 12 & 100 & 37 & 112 & 728 & 52 & 294 \\
\hline Dissolved solids, total & 12 & 12 & 100 & 33 & 91 & 109 & 59 & 102 \\
\hline \multicolumn{9}{|c|}{ Bacterial, cols $/ 100 \mathrm{~mL}$} \\
\hline Fecal coliform & 10 & 10 & 100 & 1,500 & 20,000 & 110,000 & 6,000 & 63,000 \\
\hline Fecal streptococcus & 10 & 10 & 100 & 3,200 & 71,500 & 110,000 & 20,000 & 95,500 \\
\hline \multicolumn{9}{|c|}{ Nutrients, mg/L } \\
\hline Nitrogen, total, as $\mathbf{N}$ & 12 & 12 & 100 & 1.2 & 2.3 & 3.7 & 1.6 & 2.8 \\
\hline $\begin{array}{l}\text { Nitrogen, ammonia plus } \\
\text { organic, total }\end{array}$ & 12 & 12 & 100 & .70 & 1.5 & 2.7 & 1.1 & 1.9 \\
\hline Phosphorus, total, as P & 12 & 12 & 100 & .10 & .30 & .70 & .20 & .50 \\
\hline Phosphorus, dissolved & 12 & 12 & 100 & .08 & .19 & .38 & .10 & .30 \\
\hline \multicolumn{9}{|c|}{ Oil and grease, $\mathrm{mg} / \mathrm{L}$} \\
\hline Oil and grease & 12 & 6 & 50 & $<1$ & $<1$ & 3 & $<1$ & 2 \\
\hline \multicolumn{9}{|c|}{ Major ions, mg/L } \\
\hline Alkalinity, total as $\mathrm{CaCO}_{3}$ & 12 & NA & NA & 33 & 37 & 71 & 35 & 50 \\
\hline Calcium, dissolved & 12 & NA & NA & 8.8 & 13 & 21 & 10 & 17 \\
\hline Chloride, dissolved & 12 & NA & NA & 1.2 & 4.7 & 8.7 & 2.9 & 6.4 \\
\hline Magnesium, dissolved & 12 & NA & NA & .8 & 2.5 & 3.4 & 1.0 & 3.1 \\
\hline Potassium, dissolved & 12 & NA & NA & 1.9 & 3.8 & 5.7 & 2.7 & 5.3 \\
\hline Sodium, dissolved & 12 & NA & NA & 2.4 & 6.9 & 9.1 & 3.5 & 8.5 \\
\hline Sulfate, dissolved & 12 & NA & NA & 2.5 & 11 & 22 & 6.5 & 19 \\
\hline \multicolumn{9}{|c|}{ Field measurements } \\
\hline $\mathrm{pH}$, standard units & 12 & NA & NA & 6.7 & 7.0 & 7.5 & 6.9 & 7.3 \\
\hline Specific conductance, $\mu \mathrm{S} / \mathrm{cm}$ & 12 & NA & NA & 91 & 146 & 208 & 100 & 167 \\
\hline Water temperature, ${ }^{\circ} \mathrm{C}$ & 12 & NA & NA & 10 & 19 & 24 & 16 & 21 \\
\hline \multicolumn{9}{|c|}{ Total organic carbon, mg/L } \\
\hline Total organic carbon & 12 & 12 & 100 & .6 & 15 & 23 & 13.3 & 17.5 \\
\hline
\end{tabular}


Table 15. Statistical summary of constituents and properties in stormwater-runoff samples for the two commercial land-use basins, sites 2 and 5, Omaha, Nebraska, 1992-93

$[\mu \mathrm{g} / \mathrm{L}$, micrograms per liter; $\mu \mathrm{S} / \mathrm{cm}$, microsiemens per centimeter at 25 degrees Celsius; $\mathrm{mg} / \mathrm{L}$, milligrams per liter; cols $/ 100 \mathrm{~mL}$, colonies per $100 \mathrm{milliliters;}$ --, no data; NA, not applicable; ${ }^{\circ} \mathrm{C}$, degrees Celsius; <, less than, based on analytical detection limit (app. B, table 3)]

\begin{tabular}{|c|c|c|c|c|c|c|c|c|}
\hline \multirow[b]{2}{*}{ Constituent or property } & \multirow{2}{*}{$\begin{array}{c}\text { Number } \\
\text { of } \\
\text { samples }\end{array}$} & \multirow[b]{2}{*}{$\begin{array}{l}\text { Number of } \\
\text { detections }\end{array}$} & \multirow[b]{2}{*}{$\begin{array}{l}\text { Percent } \\
\text { detection }\end{array}$} & \multicolumn{5}{|c|}{ Concentration or value } \\
\hline & & & & Minimum & Median & Maximum & $\begin{array}{c}\text { 25th } \\
\text { percentile }\end{array}$ & $\begin{array}{c}\text { 75th } \\
\text { percentile }\end{array}$ \\
\hline \multicolumn{9}{|c|}{ Volatile organic compounds, $\mu g / \mathrm{L}$} \\
\hline Chloroform & 12 & 1 & 8 & $<0.2$ & $<0.2$ & 0.4 & $<0.2$ & $<0.2$ \\
\hline Dichlorobromomethane & 12 & 1 & 8 & $<.2$ & $<.2$ & .2 & $<.2$ & $<.2$ \\
\hline Methyl chloride & 12 & 1 & 8 & $<.2$ & $<.2$ & .2 & $<.2$ & $<.2$ \\
\hline Toluene & 12 & 0 & 0 & $<.2$ & $<.2$ & $<.2$ & $<.2$ & $<.2$ \\
\hline
\end{tabular}

Anthracene
Benzo-A-anthracene
Benzo-A-pyrene
3,4-Benzofluoranthene
2,4-Benzo(ghi)perylene
Benzo(k)fluoranthene
Bis(2-ethylhexyl)phthalate
Chrysene
Fluoranthene
Indeno(1,2,3-CD)pyrene
Phenanthrene
Pyrene

Chlordane

4,4'-DDT

4,4'-DDE

Diazinon

Carbaryl

2,4-D

PCB-1242

PCB-1254

$\begin{array}{ll}2 & 1 \\ 2 & 1 \\ 2 & 1 \\ 2 & 1 \\ 2 & 1 \\ 2 & 1 \\ 2 & 1 \\ 2 & 2 \\ 2 & 2 \\ 2 & 1 \\ 2 & 1 \\ & 2\end{array}$

Base/neutral organic compounds, $\mu \mathrm{g} / \mathrm{L}$

\begin{tabular}{|c|c|c|c|c|c|}
\hline 8 & $<5$ & $<5$ & 9 & $<5$ & $<5$ \\
\hline 8 & $<10$ & $<10$ & 36 & $<10$ & $<10$ \\
\hline 8 & $<10$ & $<10$ & 43 & $<10$ & $<10$ \\
\hline 8 & $<10$ & $<10$ & 53 & $<10$ & $<10$ \\
\hline 8 & $<10$ & $<10$ & 32 & $<10$ & $<10$ \\
\hline 8 & $<10$ & $<10$ & 38 & $<10$ & $<10$ \\
\hline 8 & $<5$ & $<5$ & 6 & $<5$ & $<5$ \\
\hline 17 & $<10$ & $<10$ & 57 & $<10$ & $<10$ \\
\hline 17 & $<5$ & $<5$ & 150 & $<5$ & $<5$ \\
\hline 8 & $<10$ & $<10$ & 30 & $<10$ & $<10$ \\
\hline 8 & $<5$ & $<5$ & 73 & $<5$ & $<5$ \\
\hline 17 & $<5$ & $<5$ & 110 & $<5$ & $<5$ \\
\hline 9 & $<.1$ & $<.1$ & .1 & $<.1$ & $<.1$ \\
\hline 0 & $<.1$ & $<.1$ & $<.1$ & $<.1$ & $<.1$ \\
\hline 0 & $<.04$ & $<.04$ & $<.04$ & $<.04$ & $<.04$ \\
\hline -- & -- & -- & -- & -- & -- \\
\hline 0 & $\mathbf{N A}$ & $<.01$ & $<.01$ & NA & NA \\
\hline 100 & $\mathbf{N A}$ & .14 & .14 & NA & NA \\
\hline 0 & $<.1$ & $<.1$ & $<.1$ & $<.1$ & $<.1$ \\
\hline 0 & $<.1$ & $<.1$ & $<.1$ & $<.1$ & $<.1$ \\
\hline
\end{tabular}

Trace elements and total phenols, $\mu \mathrm{g} / \mathrm{L}$

Arsenic, total

$\begin{array}{rr}92 & < \\ 0 & <10 \\ 0 & < \\ 75 & < \\ 100 & \\ 100 & \\ 0 & \\ 100 & \\ 100 & 4 \\ 91 & <\end{array}$

$\begin{array}{rr}<1 & 2 \\ <10 & <10 \\ <1 & <1 \\ <1 & 3 \\ 4 & 6.5 \\ 2 & 11.5 \\ <.1 & <.1 \\ 2 & 5 \\ 40 & 80 \\ <1 & 2\end{array}$

Beryllium, total

Cadmium, total

11

0

0

Chromium, total

$$
12
$$$$
12
$$

12

$$
\begin{array}{r}
0 \\
12
\end{array}
$$$$
12
$$

10

91

$<1$

2

$<1$

3

6.5

11.5

$<.1$

5

80

2

8
$<10$
$<1$
6
12
31
$<.1$
9
170
NA

$\begin{array}{rc}2 & 3 \\ <10 & <10 \\ <1 & <1 \\ 1 & 5 \\ 5 & 8.5 \\ 5 & 21\end{array}$

$<.1<.1$

$3 \quad 5.5$

$50 \quad 95$


Table 15. Statistical summary of constituents and properties in stormwater-runoff samples for the two commercial land-use basins, sites 2 and 5, Omaha, Nebraska, 1992-93--Continued

\begin{tabular}{|c|c|c|c|c|c|c|c|c|}
\hline \multirow[b]{2}{*}{ Constituent or property } & \multirow{2}{*}{$\begin{array}{c}\text { Number } \\
\text { of } \\
\text { samples }\end{array}$} & \multirow[b]{2}{*}{$\begin{array}{l}\text { Number of } \\
\text { detections }\end{array}$} & \multirow[b]{2}{*}{$\begin{array}{l}\text { Percent } \\
\text { detection }\end{array}$} & \multicolumn{5}{|c|}{ Concentration or value } \\
\hline & & & & Minimum & Median & Maximum & $\begin{array}{c}\text { 25th } \\
\text { percentile }\end{array}$ & $\begin{array}{c}\text { 75th } \\
\text { percentile }\end{array}$ \\
\hline \multicolumn{9}{|c|}{ Oxygen demand, mg/L } \\
\hline $\begin{array}{l}\text { Biochemical oxygen } \\
\text { demand }\end{array}$ & 12 & 12 & 100 & 6.8 & 13 & 32 & 11 & 18 \\
\hline Chemical oxygen demand & 12 & 12 & 100 & 31 & 47 & 110 & 42 & 75 \\
\hline \multicolumn{9}{|c|}{ Properties, mg/L } \\
\hline Suspended solids, total & 12 & 12 & 100 & 31 & 84 & 370 & 52 & 170 \\
\hline Dissolved solids, 16 tal & 12 & 12 & 100 & 28 & 76 & 188 & 59 & 93 \\
\hline \multicolumn{9}{|c|}{ Bacteria, cols $/ 100 \mathrm{~mL}$} \\
\hline Fecal coliform & 11 & 11 & 100 & 200 & 5,600 & 28,000 & 1,500 & 20,000 \\
\hline Fecal streptococcus & 11 & 11 & 100 & 200 & 7,800 & 100,000 & 3,700 & 16,000 \\
\hline \multicolumn{9}{|c|}{ Nutrients, mg/L } \\
\hline Nitrogen, total, as $\mathrm{N}$ & 12 & 12 & 100 & .7 & 1.7 & 3.1 & 1.2 & 2.3 \\
\hline $\begin{array}{l}\text { Nitrogen, ammonia plus } \\
\text { organic, total }\end{array}$ & 12 & 12 & 100 & .4 & 1.0 & 1.9 & .7 & 1.5 \\
\hline Phosphorus, total, as $\mathbf{P}$ & 12 & 12 & 100 & .09 & .16 & .44 & .10 & .30 \\
\hline Phosphorus, dissolved, as P & 12 & 12 & 100 & .06 & .11 & .41 & .10 & .20 \\
\hline
\end{tabular}

Oil and grease

Alkalinity, total as $\mathrm{CaCO}_{3} \quad 12$

Calcium, dissolved

Chloride, dissolved

Magnesium, dissolved

Potassium, dissolved

Sodium, dissolved

Sulfate, dissolved

\section{2}

12
12

12

12

12

12

12

12
7

NA

NA

NA

NA

NA

NA

NA

Oil and grease, $\mathrm{mg} / \mathrm{L}$

58

$<1$

2

Major ions, $\mathbf{m g} / \mathbf{L}$

$\begin{array}{ccc}\text { NA } & 26 & 43 \\ \text { NA } & 5.6 & 14 \\ \text { NA } & 1.1 & \end{array}$

NA $\quad 1.1$

.3

1.1

1.1

2.9

NA

43

14

4.4

1.2

2.5

4.7

11

Field measurements

\begin{tabular}{lcccccccc}
$\mathrm{pH}$, standard units & 12 & NA & NA & 6.7 & 7.6 & 8.0 & 7.1 & 7.7 \\
Specific conductance, $\mu \mathrm{S} / \mathrm{cm}$ & 12 & NA & NA & 70 & 138 & 283 & 100 & 157 \\
Water temperature, ${ }^{\circ} \mathrm{C}$ & 11 & NA & NA & 15 & 20 & 24 & 24 & 17 \\
& & & Total organic carbon, $\mathbf{m g} / \mathbf{L}$ & & & \\
Total organic carbon & 12 & 12 & 100 & 5.7 & 12.5 & 37 & 7 & 21.8 \\
\hline
\end{tabular}


Table 16. Statistical summary of constituents and properties in stormwater-runoff samples for the industrial land-use basin, site 3, Omaha, Nebraska, 1992-93

$[\mu \mathrm{g} / \mathrm{L}$, micrograms per liter; $\mu \mathrm{S} / \mathrm{cm}$, microsiemens per centimeter at 25 degrees Celsius; mg/L, milligrams per liter; cols $/ 100 \mathrm{~mL}$, colonies per 100 milliliters; --, no data, NA, not applicable; ${ }^{\circ} \mathrm{C}$, degrees Celsius; $<$, less than, based on analytical detection limit (app. B, table 3 )]

\begin{tabular}{|c|c|c|c|c|c|c|c|c|}
\hline \multirow[b]{2}{*}{ Constituent or property } & \multirow[b]{2}{*}{$\begin{array}{c}\text { Number of } \\
\text { samples }\end{array}$} & \multirow[b]{2}{*}{$\begin{array}{l}\text { Number of } \\
\text { detections }\end{array}$} & \multirow[b]{2}{*}{$\begin{array}{l}\text { Percent } \\
\text { detection }\end{array}$} & \multicolumn{5}{|c|}{ Concentration or value } \\
\hline & & & & Minimum & Medlan & Maximum & $\begin{array}{c}\text { 25th } \\
\text { percentlle }\end{array}$ & $\begin{array}{c}\text { 75th } \\
\text { percentlle }\end{array}$ \\
\hline \multicolumn{9}{|c|}{ Volatile organic compounds, $\mu \mathrm{g} / \mathrm{L}$} \\
\hline Chloroform & 6 & 1 & 17 & $<0.2$ & $<0.2$ & 1.0 & $<0.2$ & $<0.2$ \\
\hline Dichlorobromomethane & 6 & 0 & 0 & $<.2$ & $<.2$ & $<.2$ & $<.2$ & $<.2$ \\
\hline Methyl chloride & 6 & 1 & 17 & $<.2$ & $<.2$ & .5 & $<.2$ & $<.2$ \\
\hline Toluene & 6 & 0 & 0 & $<.2$ & $<.2$ & $<.2$ & $<.2$ & $<.2$ \\
\hline
\end{tabular}

Base/neutral organic compounds, $\mu \mathrm{g} / \mathrm{L}$

\begin{tabular}{|c|c|c|c|c|c|c|c|c|}
\hline Anthracene & 5 & 0 & 0 & $<5$ & $<5$ & $<5$ & $<5$ & $<5$ \\
\hline Benzo-A-anthracene & 5 & 0 & 0 & $<10$ & $<10$ & $<10$ & $<10$ & $<10$ \\
\hline Benzo-A-pyrene & 5 & 0 & 0 & $<10$ & $<10$ & $<10$ & $<10$ & $<10$ \\
\hline 3,4-Benzofluoranthene & 5 & 0 & 0 & $<10$ & $<10$ & $<10$ & $<10$ & $<10$ \\
\hline 2,4-Benzo(ghi)perylene & 5 & 0 & 0 & $<10$ & $<10$ & $<10$ & $<10$ & $<10$ \\
\hline Benzo(k)fluoranthene & 5 & 0 & 0 & $<10$ & $<10$ & $<10$ & $<10$ & $<10$ \\
\hline Bis(2-ethylhexyl)phthalate & 5 & 3 & 60 & $<5$ & 6 & 7 & $<5$ & 6 \\
\hline Chrysene & 5 & 0 & 0 & $<10$ & $<10$ & $<10$ & $<10$ & $<10$ \\
\hline Fluoranthene & 5 & 3 & 60 & $<5$ & 5 & 13 & $<5$ & 7 \\
\hline Indeno(1,2,3-CD)pyrene & 5 & 0 & 0 & $<10$ & $<10$ & $<10$ & $<10$ & $<10$ \\
\hline Phenanthrene & 5 & 1 & 20 & $<5$ & $<5$ & 6 & $<5$ & $<5$ \\
\hline Pyrene & 5 & 2 & 40 & $<5$ & $<5$ & 9 & $<5$ & 6 \\
\hline \multicolumn{9}{|c|}{ Pesticides and polychlorinated biphenyls, $\mu \mathrm{g} / \mathrm{L}$} \\
\hline Chlordane & 5 & 1 & 20 & $<.1$ & $<.1$ & .1 & $<.1$ & $<.1$ \\
\hline 4,4'-DDT & 5 & 1 & 20 & $<.1$ & $<.1$ & .1 & $<.1$ & $<.1$ \\
\hline 4,4'-DDE & 5 & 1 & 20 & $<.04$ & $<.04$ & .11 & $<.04$ & $<.04$ \\
\hline Diazinon & 0 & -- & -- & -- & -- & -- & -- & -- \\
\hline Carbaryl & 0 & -- & -- & -- & - & -- & -- & $-\cdot$ \\
\hline 2,4-D & 0 & - & - & -- & -- & - & - & -- \\
\hline PCB- 1242 & 5 & 0 & 0 & $<.1$ & $<.1$ & $<.1$ & $<.1$ & $<.1$ \\
\hline PCB-1254 & 5 & 1 & 20 & $<.1$ & $<.1$ & .2 & $<.1$ & $<.1$ \\
\hline
\end{tabular}

Trace elements and total phenols, $\mu \mathrm{g} / \mathrm{L}$

\begin{tabular}{|c|c|c|c|c|c|c|c|c|}
\hline Arsenic, total & 6 & 6 & 100 & 2 & 5 & 11 & 3 & 9 \\
\hline Beryllium, total & 6 & 0 & 0 & $<10$ & $<10$ & $<10$ & $<10$ & $<10$ \\
\hline Cadmium, total & 6 & 5 & 83 & $<1$ & 2 & 4 & 2 & 3 \\
\hline Chromium, total & 6 & 6 & 100 & 6 & 13 & 30 & 7 & 17 \\
\hline Copper, total & 6 & 6 & 100 & 15 & 27 & 70 & 19 & 37 \\
\hline Lead, total & 6 & 6 & 100 & 22 & 72 & 180 & 30 & 96 \\
\hline Mercury, total & 6 & 1 & 17 & $<.1^{\circ}$ & $<.1$ & .2 & $<.1$ & $<.1$ \\
\hline Nickel, total & 6 & 6 & 100 & 8 & 17 & 39 & 10 & 27 \\
\hline Zinc, total & 6 & 6 & 100 & 150 & 285 & 640 & 210 & 300 \\
\hline Phenols, total & 5 & 4 & 80 & $<1$ & 4 & 5 & 2 & 4 \\
\hline
\end{tabular}


Table 16. Statistical summary of constituents and properties in stormwater-runoff samples for the industrial landuse basin, site 3, Omaha, Nebraska, 1992-93--Continued

\begin{tabular}{|c|c|c|c|c|c|c|c|c|}
\hline \multirow[b]{2}{*}{ Constituent or property } & \multirow[b]{2}{*}{$\begin{array}{c}\text { Number of } \\
\text { samples }\end{array}$} & \multirow[b]{2}{*}{$\begin{array}{l}\text { Number of } \\
\text { detections }\end{array}$} & \multirow[b]{2}{*}{$\begin{array}{l}\text { Percent } \\
\text { detection }\end{array}$} & \multicolumn{5}{|c|}{ Concentration or value } \\
\hline & & & & Minimum & Median & Maximum & $\begin{array}{c}\text { 25th } \\
\text { percentile }\end{array}$ & $\begin{array}{c}\text { 75th } \\
\text { percentile }\end{array}$ \\
\hline \multicolumn{9}{|c|}{ Oxygen demand, mg/L } \\
\hline $\begin{array}{l}\text { Biochemical oxygen } \\
\text { demand }\end{array}$ & 6 & 6 & 100 & 11 & 19 & 32 & 11 & 22 \\
\hline Chemical oxygen demand & 6 & 6 & 100 & $<10$ & 115 & 180 & 42 & 120 \\
\hline \multicolumn{9}{|c|}{ Properties, mg/L } \\
\hline Suspended solids, total & 6 & 12 & 100 & 358 & 606 & 1,860 & 406 & 1,225 \\
\hline Dissolved solids, total & 6 & 12 & 100 & 64 & 90 & 166 & 76 & 103 \\
\hline \multicolumn{9}{|c|}{ Bacteria, cols/100 mL } \\
\hline Fecal coliform & 6 & 6 & 100 & 2,000 & 10,850 & 36,000 & 2,650 & 24,000 \\
\hline Fecal streptococcus & 6 & 6 & 100 & 7,200 & 22,000 & 100,000 & 9,100 & 46,500 \\
\hline \multicolumn{9}{|c|}{ Nutrients, mg/L } \\
\hline Nitrogen, total, as $\mathbf{N}$ & 6 & 6 & 100 & .9 & 2.7 & 3.8 & 1.2 & 3.0 \\
\hline $\begin{array}{l}\text { Nitrogen, ammonia plus } \\
\text { organic, total }\end{array}$ & 6 & 6 & 100 & .4 & 1.7 & 2.9 & .7 & 2.1 \\
\hline Phosphorus, total, as P & 6 & 6 & 100 & .13 & .26 & .55 & .15 & .50 \\
\hline Phosphorus, dissolved, as P & 6 & 6 & 100 & .09 & .13 & .25 & .11 & .18 \\
\hline \multicolumn{9}{|c|}{ Oil and grease, mg/L } \\
\hline Oil and grease & 5 & 5 & 100 & 1 & 2 & 4 & 1 & 3 \\
\hline \multicolumn{9}{|c|}{ Major ions, mg/L } \\
\hline Alkalinity, total as $\mathrm{CaCO}_{3}$ & 6 & NA & NA & 65 & 80 & 130 & 69 & 95 \\
\hline Calcium, dissolved & 6 & NA & NA & 11 & 14.5 & 29 & 11.8 & 20 \\
\hline Chloride, dissolved & 6 & NA & NA & 6.2 & 10.4 & 20 & 7.1 & 16.3 \\
\hline Magnesium, dissolved & 6 & NA & NA & 1.3 & 1.9 & 4.7 & 1.4 & 2.9 \\
\hline Potassium, dissolved & 6 & NA & NA & 2.3 & 3.2 & 5.3 & 2.5 & 4.0 \\
\hline Sodium, dissolved & 6 & NA & NA & 4.9 & 8.8 & 14 & 5.5 & 11.8 \\
\hline Sulfate, dissolved & 6 & NA & NA & 8.1 & 13 & 37 & 10 & 21 \\
\hline \multicolumn{9}{|c|}{ Field measurements } \\
\hline $\mathrm{pH}$, standard units & 6 & NA & NA & 7.1 & 7.5 & 8.3 & 7.5 & 8.0 \\
\hline $\begin{array}{l}\text { Specific conductance, } \\
\mu \mathrm{S} / \mathrm{cm}\end{array}$ & 6 & NA & NA & 130 & 210 & 395 & 142 & 267 \\
\hline Water temperature, ${ }^{\circ} \mathrm{C}$ & 5 & NA & NA & 12 & 17 & 24 & 15 & 18 \\
\hline \multicolumn{9}{|c|}{ Total organic carbon, $\mathrm{mg} / \mathrm{L}$} \\
\hline Total organic carbon & 6 & 6 & 100 & 16 & 22.5 & 45 & 19 & 26 \\
\hline
\end{tabular}


table 5). The four most commonly detected compounds were bis(2-ethylhexyl)phthalate, fluoranthene, phenanthrene, and pyrene. Bis(2ethylhexyl)phthalate is used as a plasticizer, an organic compound added to a high-density polymer both to facilitate processing and to increase the flexibility and toughness of the final product by solution of the polymer molecule (Sax and Lewis, 1987). Fluoranthene, phenanthrene, and pyrene are derived from coal tar (Sax and Lewis, 1987). The presence of these compounds might be an indicator of leaching from road surfaces or roofing materials.

Although more base/neutral organic compounds were detected in samples collected from the residential basins, concentrations were less than the USEPA MCLs for drinking water. Statistical summaries of the 12 compounds detected are listed in tables 14-16. Median concentrations of the four compounds were less than the analytical detection limit (less than $5 \mu \mathrm{g} / \mathrm{L}$ ) in all basins except the industrial basin, where median concentrations of bis(2-ethylhexyl)phthalate $(6 \mu \mathrm{g} / \mathrm{L})$ and fluoranthene $(5 \mu \mathrm{g} / \mathrm{L})$ exceeded the detection limit. Phen-anthrene was detected in the commercial and industrial basins but median concentrations were less than the detection limit. Chrysene was detected in one of two commercial basins (site 5) but in less than 17 percent of the samples collected at two commercial sites. Eleven base/neutral compounds having concentrations ranging from 9 to $150 \mu \mathrm{g} / \mathrm{L}$ were detected in a commercial basin (site 5) during a storm-runoff event May 22, 1993. This was not a typical sampling event during this study because 11 of the 12 base/neutral organic compounds were detected (appendix B, table 5). Concentrations of six compounds - benzo-A-anthracene $(36 \mu \mathrm{g} / \mathrm{L})$, benzo-A-pyrene $(43 \mu \mathrm{g} / \mathrm{L}), 3$,4-benzo-fluoranthene $(53 \mu \mathrm{g} / \mathrm{L})$, benzo(k)fluoranthene $(38 \mu \mathrm{g} / \mathrm{L})$, chrysene $(57 \mu \mathrm{g} / \mathrm{L})$ and indeno(1,2,3-CD)pyrene $(30 \mu \mathrm{g} / \mathrm{L})$ exceeded USEPA MCLs for drinking water. Four of the base/neutral compounds were detected only during the storm event of May 22, 1993.

\section{Pesticides and Polychlorinated Biphenyls}

Twenty-one pesticides and seven PCBs were analyzed in samples collected from the study area (appendix B, table 3). Not all pesticides listed were analyzed in samples from each site. Diazinon, carbaryl, and 2,4-D, pesticides commonly used on lawns and gardens, were analyzed selectively in samples collected from the residential (sites 1 and 4) and commercial (sites 2 and 5) basins. Fewer samples were collected for the pesticides diazinon, carbaryl, and 2,4-D because these compounds were not mandated by USEPA for the NPDES sampling design. Six pesticides and two PCBs were detected in the five basins (appendix B, table 6). Concentrations of pesticides ranged from $0.1 \mu \mathrm{g} / \mathrm{L}$ (chlordane and DDT) to $13 \mu \mathrm{g} / \mathrm{L}(2,4-\mathrm{D})$, none of which exceeded USEPA MCLs for drinking water. Analytical detection limits are listed in appendix B, table 3 and MCLs for the eight constituents detected are listed in appendix B, table 6. Diazinon was detected in both of two samples collected and 2,4-D was detected in all five samples collected (appendix B, table 6). The largest concentration of 2,4-D detected in samples collected from the residential basins was about 3 orders of magnitude greater than the analytical detection limit of $0.01 \mu \mathrm{g} / \mathrm{L}$. PCB-1254 was detected in samples collected from a residential basin (site 4) $(0.1 \mu \mathrm{g} / \mathrm{L})$ and the industrial basin (site 3) $(0.2 \mu \mathrm{g} / \mathrm{L})$; PCB-1242 was detected in the same residential basin (site 4$)(0.1 \mu \mathrm{g} / \mathrm{L})$. PCB concentrations were less than the MCLs of $0.5 \mu \mathrm{g} / \mathrm{L}$ established by the USEPA (1996) for drinking water. Statistical summaries of the six pesticides and two PCBs are listed in tables 14-16.

\section{Trace Elements and Total Phenols}

Fourteen trace elements and total phenols were analyzed from samples collected in the study area (appendix B, table 3). Nine trace elements and total phenols were detected in the five basins (appendix B, table 7). Analytical detection limits are listed in appendix B, table 3 and MCLs are listed in appendix $B$, table 7. Concentrations of trace elements did not exceed MCLs for drinking water established by the USEPA (1996) with the exception of beryllium and lead. Trace-element concentrations in samples collected from the industrial basin were, in general, greater than concentrations in samples collected from the residential and commercial basins; total beryllium and total mercury were the only exceptions. Statistical summaries of the nine trace elements and total phenols are listed in tables 14-16.

Copper, lead, nickel, and zinc were detected in all samples collected. Median concentrations of copper $(27 \mu \mathrm{g} / \mathrm{L})$, nickel $(17 \mu \mathrm{g} / \mathrm{L})$, and zinc $(285 \mu \mathrm{g} / \mathrm{L})$ were about 3 times greater in samples collected from the industrial basin than from the residential and commercial basins. Median concentrations of copper were $8.5 \mu \mathrm{g} / \mathrm{L}$ in the residential 
basins (table 14) and $6.5 \mu \mathrm{g} / \mathrm{L}$ in the commercial basins (table 15). The median concentration of nickel was $5 \mu \mathrm{g} / \mathrm{L}$ in both the residential and commercial basins. Median concentrations of zinc were $60 \mu \mathrm{g} / \mathrm{L}$ in the residential basins and $80 \mu \mathrm{g} / \mathrm{L}$ in the commercial basins. Median concentrations of lead in the industrial basin $(72 \mu \mathrm{g} / \mathrm{L}$ ) (table 16) were about 6 times greater than in the residential $(13.5 \mu \mathrm{g} / \mathrm{L})($ table 14$)$ and commercial $(11.5 \mu \mathrm{g} / \mathrm{L})$ (table 15) basins. Fifty-seven percent of the samples collected had lead concentrations equal to or greater than $15 \mu \mathrm{g} / \mathrm{L}$ (table 7), which is the treatment action level for public-water supplies established by the USEPA (1988). The treatment action level is the target concentration of the contaminant that, if exceeded more than 5 percent of the time, requires treatment of the water to reduce the concentration of the contaminant prior to public consumption. A concentration of beryllium $(10 \mu \mathrm{g} / \mathrm{L})$ was detected in one sample collected in a residential basin (site 1).

Arsenic was detected in 93 percent of the samples collected and chromium in 87 percent (tables 14-16). Both trace elements were detected in all six samples collected in the industrial basin (appendix B, table 7). Median concentrations of arsenic and chromium in the residential and commercial basins ranged from 2 to $5 \mu \mathrm{g} / \mathrm{L}$, and median concentrations were about 2 to 3 times greater in the industrial basin.

Cadmium was detected in five of the six samples collected in the industrial basin, but was not detected in the residential or commercial basins. Antimony, cyanide, selenium, silver, and thallium were not detected in any samples collected in the study area.

Total phenols were detected in 82 percent of the samples collected (tables 14-16). Median concen-trations were $2 \mu \mathrm{g} / \mathrm{L}$ in the residential and commercial basins, but were about twice as large $(4 \mu \mathrm{g} / \mathrm{L})$ in the industrial basin. Phenols are organic compounds used as solvents, herbicides, and as components in resins. Health advisory levels for total phenols $(6 \mathrm{mg} / \mathrm{L})$ (U.S. Environmental Protection Agency, 1996) are about 3 orders of magnitude larger than concentrations detected in the study area.

\section{Oxygen Demand, Properties, and Bacteria}

Analytical limits for constituents and properties are listed in appendix B, table 3 , and concentrations of the constituents and properties (BOD, COD, suspended solids, dissolved solids, fecal coliform, fecal streptococcus, nutrients, and oil and grease) are listed in appendix B, table 8. Statistical summaries of these constituents and properties are listed in tables 14-16.

The BOD test is the best method available for evaluating the oxygen demand associated with organic-polluted water. BOD is the quantity of oxygen used in aerobic stabilization of wastes and polluted water. The COD test is an indication of the concentration of organic matter in water. Median concentrations of BOD (19 mg/L) and COD $(115 \mathrm{mg} / \mathrm{L})$ in the industrial basin were about 1.5 to 2 times greater than in the residential and commercial basins.

High concentrations of suspended solids and dissolved solids can cause water to be unsuitable for domestic, agricultural, and industrial supply, and also can harm aquatic organisms. Suspended solids and dissolved solids in stormwater often are a result of natural weathering of rock, soil erosion, and human activity. The median concentration of suspended solids in samples collected from the industrial basin was $606 \mathrm{mg} / \mathrm{L}$, in comparison to a median concentration of $111.5 \mathrm{mg} / \mathrm{L}$ in samples collected in the residential basins and a median concentration of $84 \mathrm{mg} / \mathrm{L}$ in samples collected in the commercial basins. Median concentrations of dissolved solids in samples collected from the residential and industrial basins were about $90 \mathrm{mg} / \mathrm{L}$, in comparison to a median concentration of $76 \mathrm{mg} / \mathrm{L}$ in the commercial basins (tables 14-16). Dissolvedsolids concentrations in all samples collected did not exceed the secondary maximum contaminant level (SMCL) of $500 \mathrm{mg} / \mathrm{L}$ for drinking water established by the U.S. Environmental Protection Agency (1996).

Fecal coliform and fecal streptococcus bacteria are used as indicators of fecal contamination from humans and other warm-blooded animals. Bacteria concentrations ranged from 200 to 110,000 colonies $/ 100 \mathrm{~mL}$ (appendix B, table 8). Median concentrations of fecal coliform $(20,000$ colonies $/ 100 \mathrm{~mL})$ in samples collected in the residential basins were about twice as large as in samples collected from the industrial basin $(10,850$ colonies $/ 100 \mathrm{~mL})$ and about 3.5 times greater from the commercial basins $(5,600$ colonies/ $100 \mathrm{~mL}$ ) (tables 14-16). Median concentrations of fecal streptococcus in samples collected in the residential basins $(71,500$ colonies $/ 100 \mathrm{~mL})$ were about 3 times greater than in the industrial basin 
$(22,000$ colonies $/ 100 \mathrm{~mL})$ and about 9 times greater than in samples collected from the commercial basins $(7,800$ colonies $/ 100 \mathrm{~mL})$.

\section{Nutrlents}

Nitrogen and phosphorus are common constituents in fertilizers. Concentrations of total nitrogen as $\mathrm{N}$, total ammonia plus organic nitrogen, total phosphorus, and dissolved phosphorus were detected in all stormwater samples. Concentrations of total nitrogen ranged from 0.7 to $3.8 \mathrm{mg} / \mathrm{L}$ and total phosphorus ranged from 0.09 to $0.66 \mathrm{mg} / \mathrm{L}$ (appendix B, table 8). Median concentrations of total nitrogen were $2.3 \mathrm{mg} / \mathrm{L}$ in the residential basins and $2.7 \mathrm{mg} / \mathrm{L}$ in the industrial basin, in comparison to $1.7 \mathrm{mg} / \mathrm{L}$ in the commercial basins (tables 14-16). Median concentrations of total nitrogen and total ammonia plus organic nitrogen were greater in the industrial basin $(2.7 \mathrm{mg} / \mathrm{L}$ and $1.7 \mathrm{mg} / \mathrm{L})$ than in the residential $(2.3 \mathrm{mg} / \mathrm{L}$ and $1.5 \mathrm{mg} / \mathrm{L})$ and commercial $(1.7 \mathrm{mg} / \mathrm{L}$ and $1.0 \mathrm{mg} / \mathrm{L}$ ) basins. The median concentrations of total phosphorus were greater in samples collected from the residential basins $(0.30 \mathrm{mg} / \mathrm{L})$ than in samples collected from the commercial $(0.16 \mathrm{mg} / \mathrm{L})$ and industrial $(0.26 \mathrm{mg} / \mathrm{L})$ basins. Median concentrations of dissolved phosphorus ranged from 0.11 to $0.19 \mathrm{mg} / \mathrm{L}$, and median concentrations of total phosphorus in all samples collected in the five basins ranged from 0.16 to $0.30 \mathrm{mg} / \mathrm{L}$. MCLs have not been established for total nitrogen, ammonia plus organic nitrogen, and total and dissolved phosphorus.

\section{Oil and Grease}

Oil and grease were detected in all samples collected from the industrial basin (appendix B, table 8) and were detected in 50 percent of samples from the residential and 58 percent of samples from the commercial basins (tables 14-16). Median concentrations were less than $1 \mathrm{mg} / \mathrm{L}$ in the residential basins, in comparison to $2 \mathrm{mg} / \mathrm{L}$ in the commercial and industrial basins. No MCL has been established for oil and grease.

\section{Major Ions, Field Measurements, and Total Organic Carbon}

Data for the seven major ions analyzed, two field measurements, and total organic carbon (TOC) are listed in appendix B, table 3. Quantitative results are listed in appendix B, table 9. Statistical summaries are listed in tables 14-16.
The median concentration of alkalinity in the industrial basin was $80 \mathrm{mg} / \mathrm{L}$, and the median concentration of chloride was $10.4 \mathrm{mg} / \mathrm{L}$, which is about twice as large as median concentrations in the residential ( $37 \mathrm{mg} / \mathrm{L}$ and $4.7 \mathrm{mg} / \mathrm{L}$ ) and commercial (43 $\mathrm{mg} / \mathrm{L}$ and $4.4 \mathrm{mg} / \mathrm{L}$ ) basins (tables $14-16$ ). Median concentrations of calcium and sulfate ranged from 11.0 to $14.5 \mathrm{mg} / \mathrm{L}$ in all five basins. The largest median concentration of sodium $(8.8 \mathrm{mg} / \mathrm{L})$ was detected in the industrial basin. No MCLs have been established for chloride and sodium concentrations in drinking water. SMCLs for chloride in drinking water $(250 \mathrm{mg} / \mathrm{L})$ have been established by the USEPA (1996).

Median $\mathrm{pH}$ was 7.0 in the residential basins, 7.6 in the commercial basins, and 7.5 in the industrial basin. The median value of specific conductance $(210 \mu \mathrm{S} / \mathrm{cm})$ in the industrial basin was about 1.5 times greater than median values in the residential $(146 \mu \mathrm{S} / \mathrm{cm})$ and commercial $(138 \mu \mathrm{S} / \mathrm{cm})$ basins (tables 14-16).

Median concentration of total organic carbon $(22.5 \mathrm{mg} / \mathrm{L})$ in samples collected from the industrial basin was about 1.5 times greater than in samples collected in the residential ( $15 \mathrm{mg} / \mathrm{L})$ and commercial (12.5 mg/L) basins (tables 14-16). Even though median concentrations in samples collected from the commercial basins were smaller than median in samples from residential basins, the concentrations of the largest 25 percent of the samples collected from the commercial basins were greater than the largest 25 percent of concentrations in samples collected from the residential basins. 


\section{ESTIMATED CONSTITUENT TRANSPORT}

The USEPA regulations for NPDES require an annual constituent load calculation for the entire urban storm drainage system. Separate annual load computations must be calculated for 12 constituents: BOD, COD, suspended solids, dissolved solids, total nitrogen as $\mathrm{N}$, total ammonia plus organic nitrogen as $\mathrm{N}$, total phosphorus, dissolved phosphorus, total cadmium, total copper, total lead, and total zinc. Storm-runoff and water-quality data collected at the five sites were used to compute loads for these constituents. Stormwater-runoff loads were estimated using direct, simple, and statistical regression methods, the latter of which used regional and local equations. The three methods are described in the following sections.

\section{Direct Method for Estimating Single- Storm Constituent Loads}

Discharge and chemical data collected during the study were used to calculate stormwater-runoff volumes, constituent loads, and mean concentrations for each storm sampled for each site. Stormwaterconstituent loads for a specific storm were computed from measured data using the following equation (Oltmann and Shulters, 1989):

$$
L=6.243 \times 10^{-5}(\mathrm{RUN} \times \mathrm{CONC}),
$$

where $\quad L$ is the observed stormwater-constituent load, in pounds,

$6.243 \times 10^{-5}$ is a unit conversion factor, $R U N$ is the storm runoff volume, in cubic feet, and

CONC represents the average constituent concentration, in milligrams per liter.

The resultant load is the quantity of a constituent, in pounds, that is transported into a stream for a specific storm at a specific site. Representative average constituent concentration (CONC) is the laboratory-determined concentration for the flow-weighted composite sample collected for that particular storm (appendix B, tables 7-9). Runoff volume for each storm (RUN) was computed by accumulating the instantaneous discharge calculated using Manning's equation and recorded by a portable flow-meter device (table 17). Estimated stormwaterconstituent loads for 12 constituents and corresponding $R U N$ (storm runoff volume, in cubic feet) values are listed in table 17 . The loads varied greatly depending on sites and rainfall events. In general, the greater the runoff volume for a specific basin, the greater the loads that were produced.

\section{Simple Method for Estimating Annual Constituent Loads}

The USEPA simple method, described in detail by U.S. Environmental Protection Agency (1992a), provides a quick and reasonable estimate of the load with a minimum amount of data. Annual constituent loads for individual outfalls are calculated using the following equation:

$$
L_{i}=\left[\frac{(P)(C F)\left(R v_{i}\right)}{12}\right]\left(C_{i}\right)\left(A_{i}\right)(2.72),
$$

where $\quad L_{i}$ is the annual constituent load for site $i$, in pounds per year,

$P$ is the annual precipitation, in inches per year,

$C F$ is the correction factor that adjusts for storms in which no runoff occurs (a value of 0.9 typically is used),

$R v_{i}$ is the weighted-average runoff-rainfall ratio for the area drained by site $i$,

$C_{i}$ is the mean concentration of the constituent, in $\mathrm{mg} / \mathrm{L}$, at site $i$, and

$A_{i}$ is the stormwater contributing drainage area for site $i$, in acres.

The 30-year (1961-90) mean annual precipitation $(P) 29.56$ inches, was obtained from climatological data from the National Weather Service, North Omaha Airport Station, Omaha. A correction factor $(C F)$ of 0.9 was used for this study, and mean runoff-rainfall ratios $\left(R v_{i}\right)$ were computed from data based on flow measurements (table 13) for residential $(0.15)$, commercial $(0.38)$, and industrial (0.32) land-use basins. Stormwater contributing drainage basin areas $A_{i}$ are listed in table 1 .

Mean concentration of constituent $\left(C_{i}\right)$ is the mean concentration for a specific constituent determined from chemical analyses of the flow-weighted composite samples. To determine the mean concentration of 12 constituents by land-use basins, mean concentrations were recalculated using data (appendix B, tables 7 and 8) from sites 1 and 4 to represent residential; sites 2 and 5, commercial; and site 3 , industrial land-use basins (table 18). 


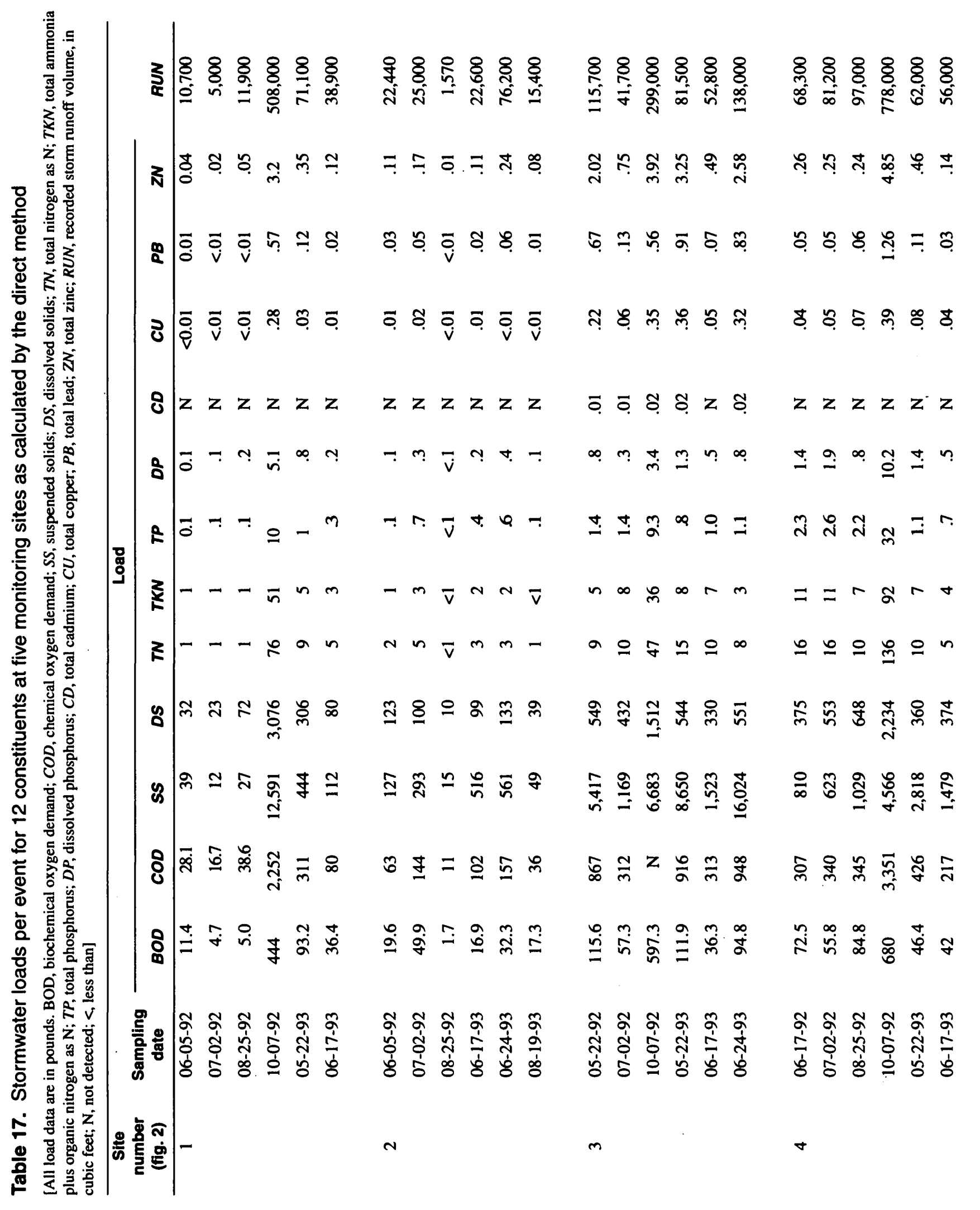




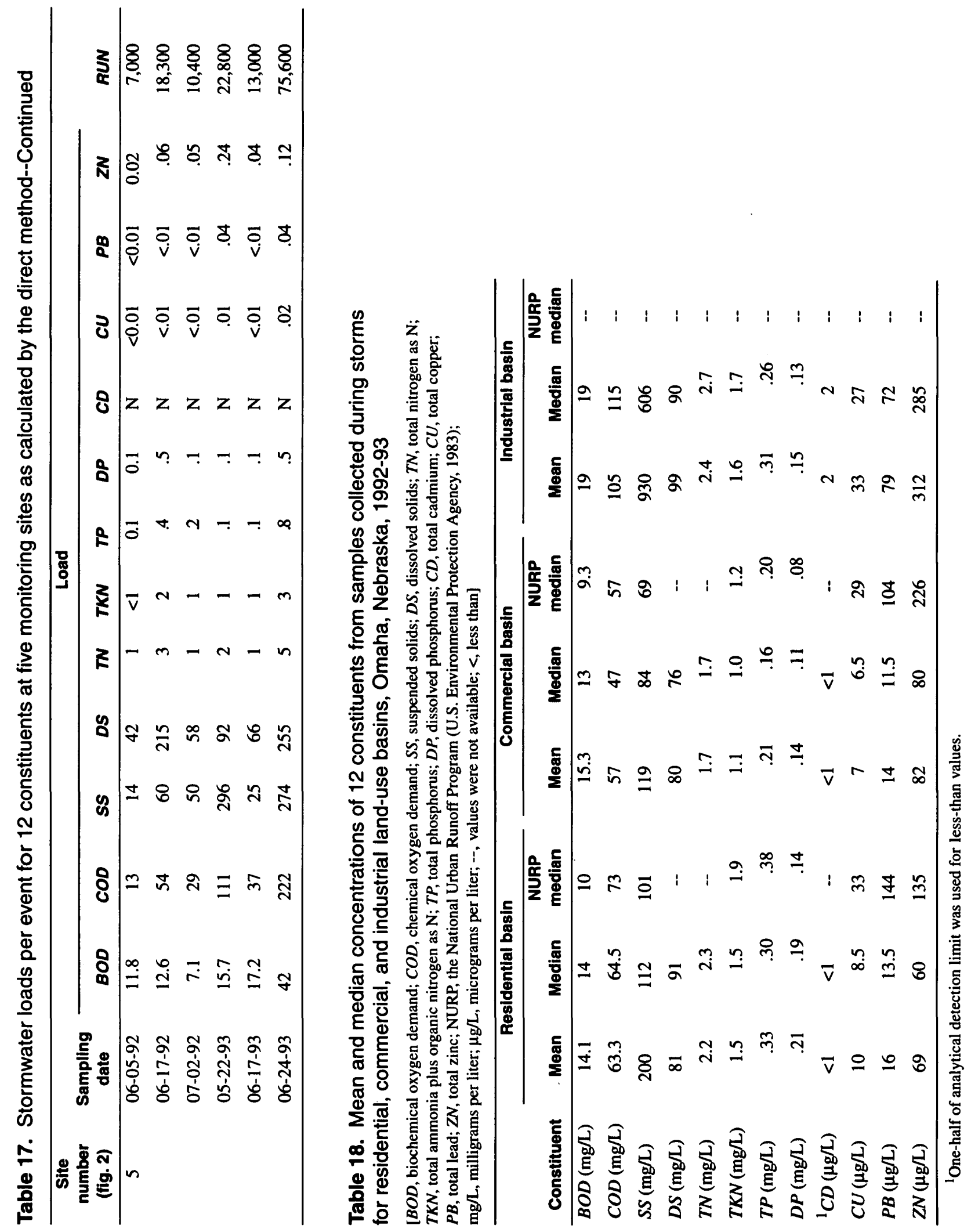


In addition to determining the median concentrations of the 12 constituents for residential, commercial, and industrial basins, concentrations were compared to median concentrations obtained from the National Urban Runoff Program's (NURP) databases (U.S. Environmental Protection Agency, 1983). The median concentrations of $B O D, C O D$, suspended solids, total ammonia plus organic nitrogen as $\mathrm{N}$, dissolved phosphorus, and total phosphorus from this study were similar to concentrations from NURP, whereas median concentrations of copper, lead, and zinc for residential land-use basins differed appreciably between this study and NURP. Median concentrations of lead $(144 \mu \mathrm{g} / \mathrm{L})$ from NURP in the residential land-use basins, for instance, was about 11 times greater than in the residential $(14 \mathrm{mg} / \mathrm{L})$ land-use basin from the City of Omaha. The NURP did not compile data on the industrial land-use basin.

Annual constituent loads for the 12 constituents for each basin, based on six sampled storms at each of the five monitoring sites, were estimated using equation 2 and are listed in table 19. By using a persite basis of the estimated annual pollutant loads, the per-watershed and city-wide annual constituent loads could be estimated.

\section{Statistical Regression Methods for Estimating Single-Storm Loads}

Stormwater-runoff loads at an unmonitored site can be estimated using either a deterministic model of runoff and transport processes in a basin, or by using a statistical model developed and calibrated from observed data.The deterministic model requires a substantial amount of historical data for the drainage areas serviced by storm-sewer outfalls. Although neither type of model can be calibrated with on-site data when estimating loads at an unmonitored site, the statistical model has the advantage of providing a measure of certainty of the estimates not provided in the deterministic model predictions.

\section{Regional Regression Analysis}

Linear-regression models were developed by the USGS (Driver and Tasker, 1990) to estimate stormwater-runoff volumes, constituent loads, and mean concentrations from basin characteristics. Regression equations were derived using the NURP database compiled by the USEPA (1983). Models of stormwater-runoff load and mean concentration for a single storm were developed for 11 constituents ( $C O D$, suspended solids, dissolved solids, total nitrogen as $\mathbf{N}$, total ammonia plus organic nitrogen as $\mathrm{N}$, total phosphorus, dissolved phosphorus, total cadmium, total copper, total lead, and total zinc) by relating concentrations and stormwater runoff (RUN) to easily measured physical, land use, and climatic characteristics (the explanatory variables) of urban basins in three regions of the United States. The three regions were defined by the ranges of annual rainfall. Annual rainfall in Region II ranges from 20 to 40 inches, thus the City of Omaha, with an average annual rainfall of 30 inches, is in Region II. The one runoff equation and 11 load equations for Region II, with the three most significant explanatory variables-total storm rainfall, total contributing drainage area, and impervious area-are listed in table 20.

The general form of the regression equation that applies to estimate stormwater-runoff loads and volumes is:

$$
Y=\beta_{0} \times X_{1}^{\beta_{1}} \times X_{2}^{\beta_{2}} \ldots X_{n}^{\beta_{n}} \times B C F
$$

where $\quad Y$ is the estimated stormwater-runoff load (response variable), $\beta_{o} \ldots \beta_{n}$ are the regression coefficients, $X_{1} \ldots . X_{n}$ are the physical, land-use, or climatic characteristics (explanatory variables),

$n$ is the number of physical, land-use, and climatic characteristics in the regression equations, and

$B C F$ is a bias-correction factor.

A bias-correction factor $(B C F)$ needs to be included in the regression equation if an unbiased estimate of the mean is to be obtained. For a more detailed discussion, the reader is referred to Driver and Tasker (1990). The effectiveness of the equation in predicting stormwater-runoff load, $Y$, is expressed by the equation's coefficient of determination, $R^{2}$, which is the ratio of the variation described by the explanatory variables to the total variation of the response variable. 
Table 19. Estimated annual constituent loads as determined by the U.S. Environmental Protection Agency simple method using data from the five sites, Omaha, Nebraska, 1992-93

(All load data are in pounds. $B O D$, biochemical oxygen demand; $C O D$, chemical oxygen demand; $S S$, suspended solids; $D S$, dissolved solids; TN, total nitrogen as $\mathrm{N} ; T K N$, total ammonia plus organic nitrogen as $\mathrm{N} ; T P$, total phosphorus; $D P$, dissolved phosphorus; $C D$, total cadmium; $C U$, total copper; $P B$, total lead; $Z N$, total zinc]

\begin{tabular}{|c|c|c|c|c|c|c|c|c|c|c|c|c|c|}
\hline \multirow{2}{*}{$\begin{array}{l}\text { Site } \\
\text { (fig. 2) }\end{array}$} & \multirow{2}{*}{$\begin{array}{c}\text { Area } \\
\text { (acres) }\end{array}$} & \multicolumn{12}{|c|}{ Load } \\
\hline & & $B O D$ & COD & SS & DS & TN & TKN & $T P$ & $D P$ & $C D$ & $C U$ & $P B$ & $Z N$ \\
\hline 1 & 339 & 4,538 & 16,457 & 34,598 & 21,311 & 583 & 377 & 67 & 49 & 0 & 2.25 & 5.01 & 21.46 \\
\hline 2 & 32 & 1,219 & 4,766 & 11,806 & 4,754 & 123 & 73 & 15 & 9 & 0 & .61 & 1.39 & 6.6 \\
\hline 3 & 101 & 3,703 & 20,464 & 181,221 & 19,295 & 464 & 308 & 60 & 29 & .37 & 6.33 & 15.33 & 60.74 \\
\hline 4 & 446 & 5,378 & 29,381 & 116,186 & 36,982 & 1,041 & 718 & 173 & 105 & 0 & 4.77 & 6.32 & 27.57 \\
\hline 5 & 129 & 4,133 & 14,485 & 22,664 & 28,378 & 526 & 340 & 56 & 47 & 0 & 1.72 & 2.66 & 21.68 \\
\hline
\end{tabular}

Table 20. Coefficients for three variable linear regression models for stormwater-runoff loads for Region II

[Driver and Tasker, 1990. $\beta_{0}$, the regression coefficient that is the intercept in the regression model; TRN, total storm rainfall; $D A$, total contributing drainage area; $I A+1$, impervious area plus 1 percent; $B C F$, bias-correction factor; $C O D$, chemical oxygen demand, in pounds; $S S$, suspended solids, in pounds; $D S$, dissolved solids, in pounds; $T N$, total nitrogen, in pounds; $T K N$, total ammonia plus organic nitrogen as nitrogen, in pounds; $T P$, total phosphorus, in pounds; $D P$, dissolved phosphorus, in pounds; $C D$, total cadmium, in pounds; $C U$, total copper, in pounds; $P B$, total lead, in pounds;

$Z N$, total zinc, in pounds; $R U N$, stormwater-runoff volume, in cubic feet; *, explanatory variable is not significant at the 5-percent level; $R^{2}$, coefficient of determination]

Equation form is: $Y=\beta_{0} \times(T R N)^{\beta_{1}} \times(D A)^{\beta_{2}} \times(I A+1)^{\beta_{3}} \times B C F$

\begin{tabular}{|c|c|c|c|c|c|c|c|c|c|}
\hline \multirow{2}{*}{$\begin{array}{c}\text { Response } \\
\text { variable } \\
\text { (I) }\end{array}$} & \multicolumn{4}{|c|}{ Regression coefficients } & \multirow[b]{2}{*}{$B C F$} & \multirow[b]{2}{*}{$\boldsymbol{A}^{2}$} & \multicolumn{2}{|c|}{$\begin{array}{c}\text { Standard error of } \\
\text { estimate }\end{array}$} & \multirow{2}{*}{$\begin{array}{c}\text { Number } \\
\text { of } \\
\text { storms }\end{array}$} \\
\hline & $\beta_{0}$ & $\beta_{1}$ & $\beta_{2}$ & $\bar{\beta}$ & & & $\%$ & Log & \\
\hline$C O D$ & 151 & 0.823 & 0.726 & 0.564 & 1.451 & 0.67 & 106 & 0.376 & 793 \\
\hline SS & 812 & 1.236 & .436 & .202 & 1.938 & .60 & 173 & .512 & 964 \\
\hline$D S$ & 3.26 & 1.251 & 1.218 & 1.964 & 1.434 & .86 & 101 & .367 & 281 \\
\hline$T N$ & 4.04 & .936 & .937 & .692 & 1.373 & .77 & 97 & .353 & 574 \\
\hline$T K N$ & 3.89 & .944 & .765 & .556 & 1.524 & .75 & 107 & .381 & 858 \\
\hline$T P$ & .697 & 1.008 & .628 & .469 & 1.790 & .62 & 120 & .411 & 1,091 \\
\hline$D P$ & .060 & .991 & .718 & .701 & 1.757 & .63 & 121 & .412 & 467 \\
\hline$C D$ & .021 & 1.367 & 1.062 & $.328^{*}$ & 1.469 & .62 & 109 & .386 & 47 \\
\hline$C U$ & .013 & .504 & .585 & .816 & 1.548 & .55 & 123 & .417 & 298 \\
\hline$P B$ & .150 & .791 & .426 & .522 & 1.665 & .43 & 135 & .442 & 943 \\
\hline $\mathrm{ZN}$ & .046 & .880 & .808 & 1.108 & 1.813 & .51 & 166 & .500 & 357 \\
\hline RUN & 62,951 & 1.127 & .809 & .522 & 1.212 & .88 & 69 & .270 & 1,353 \\
\hline
\end{tabular}

The utility of regional-regression equations in estimating loads for basins in the study area was assessed by comparing regression-derived estimates using the models in table 20 with estimates computed from the site data (table 1 and table 24). Insufficient data for cadmium were collected during the study; thus, comparison of cadmium was excluded. The discrepancy between observed and corresponding predicted values for dissolved solids and total ammonia plus organic nitrogen as $\mathbf{N}$ for six storms (designated as A, B, C, D, E, and F) in the five basins $(1,2,3,4$, and 5), for example, is illustrated in figure 3 . The regression-derived estimates were generally greater than observed stormwater-runoff loads. The accuracy of these estimates for load and runoff values produced by the regional-regression equations might be improved substantially by using only data collected on-site in the calibration of the regional-regression models. 

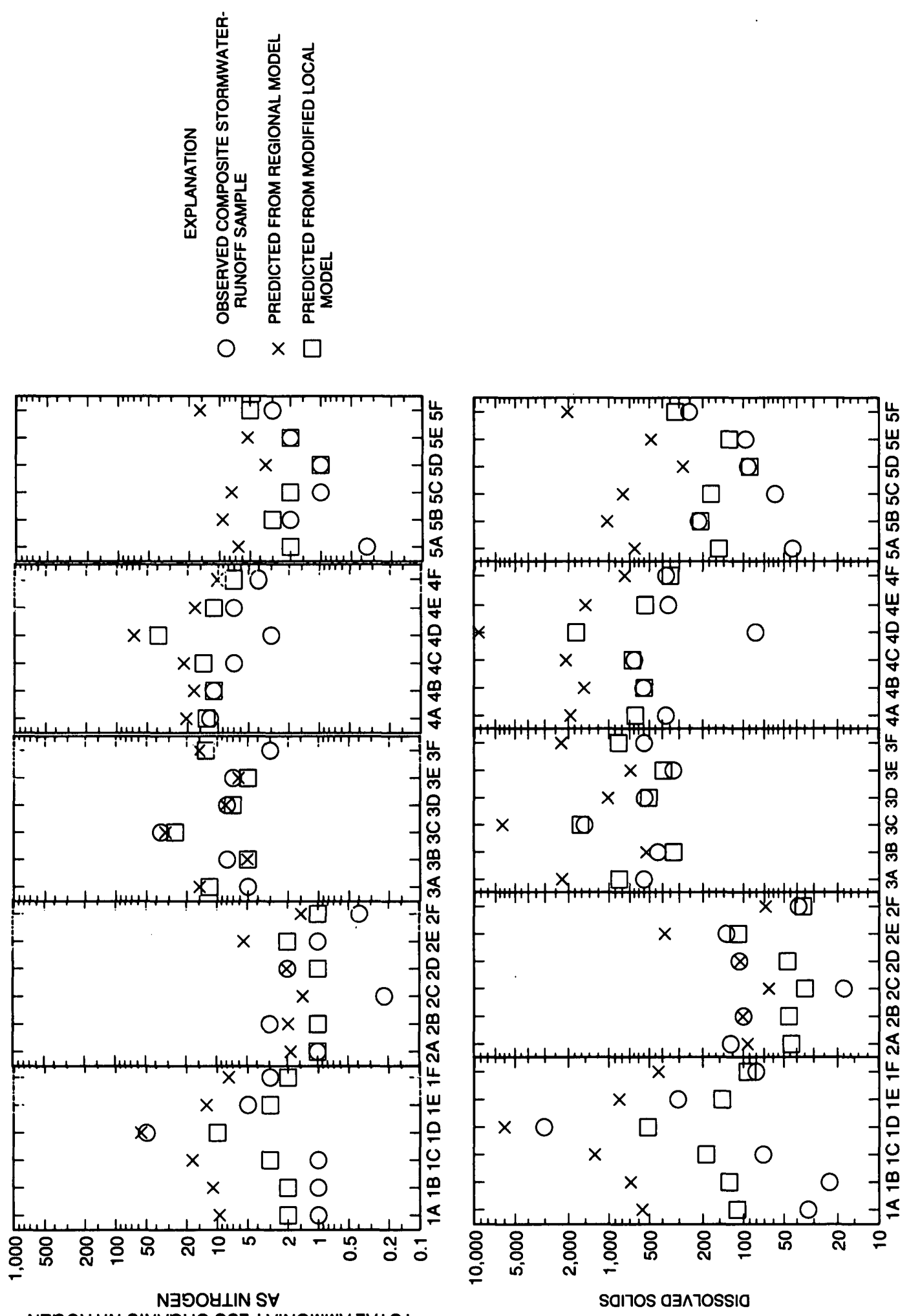

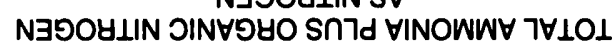

SaNnOd NI ' $ם \forall 07$ J $\exists O N \cap \forall-\forall \exists \perp \forall M W \forall O \perp S$ 


\section{Local Regression Analysis}

Local regression equations were developed for each of the 11 constituents identified for load computations (BOD, COD, suspended solids, dissolved solids, total nitrogen as $\mathrm{N}$, total ammonia plus organic nitrogen as $\mathrm{N}$, total phosphorus, dissolved phosphorus, total copper, total lead, and total zinc). An equation was not derived for total cadmium because cadmium was detected only in samples collected from site 3 .

All equations were derived as functions of total storm rainfall (TRN), total contributing drainage area $(D A)$, impervious areas $(I A)$, and landuse characteristics, and can be transformed to an analysis of covariance by using an indicator variable to identify if the basin is residential, commercial, or industrial. The form of the regression equation, using a logarithmic transformation (base 10) of the response variable of $Y$ and explanatory variables of $T R N, D A$, and $I A$, is given by:

$$
\begin{gathered}
\log Y=\beta_{0}+\beta_{1} \log (T R N)+\beta_{2} \log (D A) \\
+\beta_{3} \log (I A+1)+\beta_{4} X_{1}+\beta_{5} X_{2},
\end{gathered}
$$

where $\quad Y$ is the estimated stormwater-runoff load or volume (response variable), $\beta_{0} \ldots \beta_{5}$ are the regression coefficients, and $X_{1}, X_{2}$ are indicator variables. Defined as:

$$
\begin{aligned}
& X_{1} \quad X_{2} \\
& 00 \text { Residential land use, } \\
& 10 \text { Commercial land use, and } \\
& \begin{array}{lll}
0 & 1 & \text { Industrial land use. }
\end{array}
\end{aligned}
$$

The response variables, regression coefficients, coefficient of determination $\left(R^{2}\right)$, standard error of estimate (expressed in percent and in log forms), and number of storms are listed in table 21. $R^{2}$ indicates the proportion of the total variation of the response variable described by the explanatory variables. Therefore, the value of $R^{2}$ is used as a summary measure to judge the fit of the regression model to the data. The standard error of estimate is an estimate of the standard deviation about the regression. The smaller the standard error of estimate, the more precise will be the estimate of the response variable.
However, the accuracy of the equations cannot be compared based on the standard error of estimate if the units of the response variable in each case are different. Thus, the standard error of estimate, in percent, was calculated for all the regression models using the following formula.

$$
S E=100\left[e^{\left(\sigma^{2} \times 5.302\right)}-1\right]^{\frac{1}{2}}
$$

where $S E$ is the standard error of estimate, in percent, and

$\sigma^{2}$ is the mean square error in log (base 10) units.

The values of $R^{2}$ in the local-regression equations ranged from 0.60 to 0.83 (table 21). Standard errors of estimate ranged from 72 to 160 percent. Because the indicator variables in the equations were significant at the 5-percent level, a significant difference in storm loads is evident for the three types of land use after adjusting for the effect of the explanatory variables $T R N, D A$, and $I A$.

The $R^{2}$ statistics were sufficiently large and the $S E$ statistics were sufficiently small to imply that the relations between these estimates and three explanatory variables are mathematically definable (table 21). The local regression equations could be used to make reasonable estimates of stormwaterrunoff constituent loads and volumes at gaged and ungaged urban outfalls and basins in the City of Omaha. The number of storms used to develop the local regression equations for 11 constituent loads was small (30) (table 21) in comparison to regional equations, where the number of storms ranged from 47 to 1,091 (table 20). Because of the small number of samples used, the associated confidence level for the local regression equations was not high.

\section{Adjusted Regional Regression Equations}

Hoos and Sisolak (1993) proposed four modeladjustment procedures (MAPs) to estimate stormwater-runoff quality at gaged and ungaged urban basins from existing regression equations (DriverTasker equations) by combining or weighting them with information from local data. 
Table 21. Summary of coefficients for local regression models for stormwater-runoff loads for drainage basins, Omaha, Nebraska, 1992-93

[Y, stormwater-runoff load; $\beta_{0}-\beta_{5}$, regression coefficients; $T R N$, total storm rainfall, in inches; $D A$, total contributing drainage area, in square miles; $I A+1$, impervious area plus 1 percent, in percent; $B O D$, biochemical oxygen demand, in pounds; $C O D$, chemical oxygen demand, in pounds; $S S$, suspended solids, in pounds; $D S$, dissolved solids, in pounds; $T N$, total nitrogen as nitrogen, in pounds; $T K N$, total ammonia plus organic nitrogen as nitrogen, in pounds; $T P$, total phosphorus, in pounds; $D P$, dissolved phosphorus, in pounds; $C U$, total copper, in pounds; $P B$, total lead, in pounds; $Z N$, total zinc, in pounds; $R U N$, stormwater-runoff volume, in cubic feet $\left(\mathrm{ft}^{3}\right) ; X_{1}$ and $X_{2}$, indicator variables; $R^{2}$, coefficient of determination; *, explanatory variable is not significant at the 5-percent level; \%, percent]

Equation form is: $\log Y=\beta_{0}+\beta_{1} \log (\mathrm{TRN})+\beta_{2} \log (D A)+\beta_{3} \log (I A+1)+\beta_{4} X_{1}+\beta_{5} X_{2}$

\begin{tabular}{|c|c|c|c|c|c|c|c|c|c|c|}
\hline \multirow{2}{*}{$\begin{array}{c}\text { Response } \\
\text { variable } \\
(Y)\end{array}$} & \multicolumn{6}{|c|}{ Regression coefficients } & \multirow[b]{2}{*}{$\boldsymbol{R}^{2}$} & \multicolumn{2}{|c|}{$\begin{array}{c}\text { Standard error of } \\
\text { estimate }\end{array}$} & \multirow{2}{*}{$\begin{array}{l}\text { Num- } \\
\text { ber of } \\
\text { storms }\end{array}$} \\
\hline & $\beta_{0}$ & $\beta_{1}$ & $\beta_{2}$ & $\bar{\beta}$ & $\overline{\beta_{4}}$ & $\beta_{5}$ & & $\%$ & $(\log )$ & \\
\hline$B O D$ & -13.73 & 1.17 & $-0.17^{*}$ & 10.17 & -3.16 & $-3.24^{*}$ & 0.71 & 92 & 0.34 & 30 \\
\hline$C O D$ & -19.79 & .89 & $.19 *$ & 14.48 & -4.48 & -4.71 & .60 & 124 & .42 & 30 \\
\hline$S S$ & -33.80 & 1.31 & $-.66^{*}$ & 23.77 & -7.36 & -7.41 & .75 & 160 & .49 & 30 \\
\hline$D S$ & -17.18 & 1.11 & $.23 *$ & 12.94 & -3.65 & -3.95 & .78 & 75 & .29 & 30 \\
\hline$T N$ & -19.25 & 1.15 & $.05^{*}$ & 13.26 & -3.96 & -4.25 & .73 & 95 & .35 & 30 \\
\hline$T K N$ & -20.36 & 1.14 & $.13^{*}$ & 13.87 & -4.12 & -4.44 & .72 & 99 & .36 & 30 \\
\hline$T P$ & 6.55 & 1.52 & $-.14^{*}$ & 13.30 & -4.23 & -4.52 & .81 & 88 & .33 & 30 \\
\hline$D P$ & 5.49 & 1.35 & $-.01 *$ & 11.44 & -3.62 & -3.90 & .83 & 72 & .28 & 30 \\
\hline$C U$ & 4.31 & 1.13 & $.31^{*}$ & 11.99 & -3.99 & -3.62 & .81 & 88 & .33 & 30 \\
\hline$P B$ & 3.01 & 1.24 & $.91 *$ & 8.96* & -3.64 & $-2.82^{*}$ & .72 & 149 & .47 & 30 \\
\hline$Z N$ & 3.18 & 1.22 & $.29 *$ & 7.66* & -2.57 & $-2.00^{*}$ & .76 & 103 & .37 & 30 \\
\hline$R U N$ & 8.76 & 1.06 & $.04 *$ & 7.54 & -2.45 & -2.71 & .77 & 76 & .29 & 325 \\
\hline
\end{tabular}

The four MAPs are:

1. Single-factor regression against the predicted values (load or concentration or both) from a regional regression model $P u$ (termed MAP-1F-P),

2. regression against $P u$ (termed MAP-R-P),

3. regression against $P u$ and local data (termed MAP-R-P $+n V$ ), and

4. weighted combination of $P u$ and a localregression prediction (termed MAP-W).

One of the procedures for adjusting the regional regression models, regression against $P u$ and local data (MAP-R-P $+n V$ ), was selected for adjusting the regional models to estimate constituent loads after examining the Omaha (local) database. Statistical tests and figure 3 indicate that the pattern of correspondence between the observed and predicted values from the local database has the following two characteristics, both of which support the model adjustment as a valid approach:

1. The direction of bias of predicted values relative to observed values of all 11 constituent loads is consistent (that is, overestimated) with the exception of suspended solids. A Wilcoxon signed rank test (SAS Institute, Inc., 1982) on the predicted and observed paired data at a 5-percent significance level indicated that consistent direction of bias existed.

2. The predicted and observed values are strongly and positively correlated, so that the variation in predicted values explains much of the variation in the observed values. A Spearman correlation coefficient test (SAS Institute, Inc., 1982 ) indicated that the correlations between the regional model predicted and observed values for all 11 constituent loads were significant at a 5-percent level. This implies that the regional model does explain the relation between the response variable and the explanatory variables.

MAP-R-P + nV log-transformed observed values $(O)$ (Hoos and Sisolak, 1993) are regressed against several independent variables (including the log-transformed predicted values $P u$, from the unadjusted regional model in table 20 ) in a traditional multiple linear regression: 


$$
\log O=\beta_{o}+\beta_{1} \log P u+\beta_{2} \log V_{1}+\ldots+\beta_{n+1} \log V_{n},
$$

where $\beta_{0}, \beta_{1}, \ldots, \beta_{n+1}$ are the regression coefficients fitted from multiple linear regression analysis of the calibration of the local data set, and $V_{1}, V_{2}, \ldots, v_{n}$ are the values of additional explanatory variables from the calibration set.

The prediction at an unmonitored site $i\left(P a_{i}\right)$ is then calculated from equation 6 by detransformed form as:

$$
P a_{i}=\beta_{0}^{\prime} \times P u_{1}^{\beta_{1}} \times V_{1}^{\beta_{2}} \times \ldots \mathrm{V}_{n}^{\beta_{n+1}} \times B C F,
$$

where $\quad \beta^{\prime}{ }_{0}={ }_{10} \beta_{0}$, and

$B C F$ is the bias-correction factor.

The detransformation of a regression model provides a consistent estimate of median response, but systematically underestimates the mean response. A $B C F$ is included to obtain an unbiased estimate of the mean responses; a good approximation equation was defined by Ferguson (1986) as:

$$
B C F=10^{0.5 S E^{2}} \text {, }
$$

where $S E$ is the standard error of estimate, in log units.

Local regression models indicated that landuse type is significant; thus, three additional explanatory variables in the Omaha database-residential (LUR), commercial (LUC), and industrial (LUI) land use-were selected for the multiple-regression analysis. Results of the analysis are listed in table 22 . The significance of regression is determined by hypothesis testing on the slopes and intercepts at a 5-percent level. All 11 regression models were significant at the 5-percent level, except the land-use variables in some of the models, such as $C O D$, total nitrogen as $\mathrm{N}$, trace elements, and RUN models, which were insignificant at the 5-percent level. Values of $R^{2}$ ranged from 0.54 to 0.75 and standard errors of estimate ranged from 82 to 200 percent (table 22). The greater the values of $R^{2}$, the more the variability in the stormwater-runoff loads is explained by the regression model. By comparing $R^{2}$ of the adjusted regional models with unadjusted regional models (table 20), the adjusted models for suspended solids, total phosphorus, dissolved phosphorus, copper, lead, and zinc loads have larger $R^{2}$ values than the unadjusted models.
For example, 75-percent of the variability of total phosphorus in stormwater-runoff loads is explained by the total phosphorus regression model of four explanatory variables. The standard errors of estimate generally were less than 135 percent except for the models of stormwater-runoff loads of suspended solids (187 percent) and lead (200 percent) (table 22 ), indicating a relatively small departure from mean stormwater-runoff load estimations.

The stormwater-runoff load and volume equations developed by the regression analysis in tables 21 and 22 can be applied to estimate constituent loads and volumes for every storm event, month, and year by outfall and by basin. The stormwater-runoff loads and volumes were estimated using adjusted regional regression models for each individual storm event at five sites (table 23).

Long-term climatic data were compiled to calculate the monthly and annual loads (table 24). The volumes of precipitation for all storms that occurred during 1983-92 with less than 0.1 inch were excluded from the statistics. Snowfall duration was not taken into account because of the time lag between a snow storm and resulting runoff. Mean monthly and annual stormwater-runoff loads and volumes were estimated for a residential basin (site 1)(table 25). Annual loads were estimated for each of the 11 constituents for the five monitoring sites (table 26).

For example, the average number of storms in June in the study area was five (table 24); therefore, the total $C O D$ load for a residential basin (site 1) for the month of June was calculated to be:

COD load (pounds per month) $=$ COD load (pounds per event) $\mathrm{x}$ number of storms for that month

For June, it would be:

$$
\begin{gathered}
184.72 \text { (pounds per event) }(\text { eq. } 12) \times 5 \text { events }(\text { table } 24) \\
=923.60 \text { pounds }(\text { table } 25)
\end{gathered}
$$


Table 22. Coefficients for the MAP-R-P + nV adjusted regression models for stormwater-runoff loads and volumes at monitored/unmonitored basins, Omaha, Nebraska, 1992-93

[Hoos and Sisolak, 1993; $\beta_{0}^{1}$, regression coefficient, intercept in the regression model; $P a_{i}$, prediction at unmonitored site i; $P u_{i}$, log-transformed predicted loads and volumes from the unadjusted regional model in table $20 ; B C F$, bias-correction factor; $L U I$, percent industrial land use; $L U C$, percent commercial land use; $L U R$, percent residential land use; $C O D$, chemical oxygen demand, in pounds; $S S$, suspended solids, in pounds; $D S$, dissolved solids, in pounds; $T N$, total nitrogen as nitrogen, in pounds; $T K N$, total ammonia plus organic nitrate as nitrogen, in pounds; $T P$, total phosphorus, in pounds; $D P$, dissolved phosphorus, in pounds; $C U$, total copper, in pounds; $P B$, total lead, in pounds; $Z N$, total zinc, in pounds; $R U N$, storm-runoff volume in cubic feet; \%, percent; *, the explanatory variable is not significant at the 5-percent level]

Equation form is: $\quad P a_{i}=\beta_{0}^{1}\left(P u_{i}\right)^{\beta_{1}} \times(L U R)^{\beta_{2}} \times(L U C)^{\beta_{3}} \times(L U I)^{\beta_{4}} \times B C F$

\begin{tabular}{|c|c|c|c|c|c|c|c|c|c|}
\hline \multirow{2}{*}{$\begin{array}{c}\text { Response } \\
\text { variable } \\
\left(P_{a_{1}}\right)\end{array}$} & \multicolumn{5}{|c|}{ Regression coetficients } & \multirow[b]{2}{*}{$B C F$} & \multirow[b]{2}{*}{$R^{2}$} & \multicolumn{2}{|c|}{$\begin{array}{c}\text { Standard error of } \\
\text { estimate }\end{array}$} \\
\hline & $\beta_{0}^{1}$ & $\beta_{1}$ & $\beta_{2}$ & $\beta_{3}$ & $\beta_{4}$ & & & $\%$ & $\log$ \\
\hline$C O D$ & 5,840 & 0.667 & $-0.689 *$ & $-1.752^{*}$ & $-1.451^{*}$ & 1.254 & 0.54 & 135 & 0.443 \\
\hline SS & 483,393 & .845 & -1.214 & -2.921 & -2.279 & 1.385 & .70 & 187 & .532 \\
\hline$D S$ & 1,317 & .646 & -.580 & -1.398 & $-1.202^{*}$ & 1.119 & .73 & 82 & .313 \\
\hline$T N$ & 575 & .804 & $-.658^{*}$ & $-1.510^{*}$ & $-1.278^{*}$ & 1.182 & .66 & 108 & .381 \\
\hline$T K N$ & 783 & .932 & -.731 & -1.707 & $-1.479 *$ & 1.178 & .69 & 106 & .377 \\
\hline$T P$ & 3,317 & 1.174 & -.891 & -2.036 & -1.830 & 1.177 & .75 & 106 & .376 \\
\hline$D P$ & 2,675 & 1.255 & -.762 & -1.555 & -1.488 & 1.158 & .74 & 98 & .357 \\
\hline$C U$ & 392 & 1.064 & $-.664 *$ & $-1.811^{*}$ & $-1.293^{*}$ & 1.206 & .72 & 117 & .403 \\
\hline$P B$ & 6.2 & .982 & $-.340^{*}$ & $-1.151^{*}$ & $-.553^{*}$ & 1.418 & .61 & 200 & .551 \\
\hline$Z N$ & 9.8 & .813 & $-.392 *$ & $-.928 *$ & $-.462 *$ & 1.238 & .66 & 129 & .431 \\
\hline$R U N$ & 524 & .824 & $-.536^{*}$ & $-1.092^{*}$ & $-.931^{*}$ & 1.149 & .66 & 95 & .347 \\
\hline
\end{tabular}

mean annual $C O D$ load, $6,247.66$ pounds (table 25 ), was obtained by summing 12 months of $C O D$ loads.

$$
\begin{aligned}
C O D \# / \text { event }= & 5,840 \times\left(P u_{i}\right)^{0.667}(L U R)^{-0.689} \times(L U C)^{-1.752} \\
& \times(L U I)^{-1.451} \times 1.254 \text { (table 22) }
\end{aligned}
$$

where:

$$
\begin{gathered}
P u_{i}(C O D)=151 \times(T R N)^{0.823} \times(D A)^{0.726} \\
\times(I A+1)^{0.564} \times 1.451 \text { (table 20) }
\end{gathered}
$$

Using a mean rainfall value of 0.72 inches (table 24), the values for the explanatory variables, $D A$ and $I A$ from table 1 , the regression equation becomes:

$$
\begin{aligned}
C O D & =5,840 \times(757.7)^{0.667} \times(82)^{-0.689} \times(18)^{-1.752} \\
& \times 1^{-1.451} \times 1.254=184.72 \text { pounds per event }
\end{aligned}
$$

and
The modified 10 constituent load equations, stormwater-runoff regression models, and a local $B O D$ regression equation can be applied to gaged and ungaged outfalls and basins in the City of Omaha. 
Table 23. Estimated stormwater-runoff event loads and volumes for five monitoring sites using adjusted regional regression models, Omaha, Nebraska, 1992-93

[Values are in pounds, unless otherwise noted. $B O D$, biochemical oxygen demand; $C O D$, chemical oxygen demand; SS, suspended solids; $D S$, dissolved solids; $T N$, total nitrogen as nitrogen; $T K N$, total ammonia plus organic nitrogen as nitrogen; $T P$, total phosphorus; $D P$, dissolved phosphorus; $C U$, total copper; $P B$, total lead; $Z N$, total zinc; $R U N$, storm-runoff volume, in cubic feet]

\begin{tabular}{|c|c|c|c|c|c|c|c|c|c|c|c|c|c|}
\hline Site & $\begin{array}{l}\text { Sampling } \\
\text { date }\end{array}$ & $B O D^{1}$ & $C O D$ & SS & $D S$ & $T N$ & TKN & $T P$ & $D P$ & $c u$ & $P B$ & $Z N$ & RUN \\
\hline \multirow[t]{6}{*}{1} & $6-5-92$ & 21 & 112 & 139 & 111 & 3 & 2 & 0.3 & 0.2 & 0.02 & 0.03 & 0.14 & 26,668 \\
\hline & $7-2-92$ & 25 & 123 & 164 & 127 & 4 & 2 & .4 & .3 & .02 & .04 & .15 & 30,889 \\
\hline & $8-25-92$ & 44 & 161 & 274 & 188 & 6 & 3 & .7 & .5 & .02 & .06 & .22 & 48,742 \\
\hline & $10-7-92$ & 189 & 317 & 1,003 & 514 & 14 & 10 & 2.9 & 2.3 & .04 & .15 & .52 & 154,486 \\
\hline & $5-22-93$ & 30 & 134 & 193 & 144 & 4 & 3 & .4 & .3 & .02 & .04 & .17 & 35,759 \\
\hline & $6-17-93$ & 16 & 99 & 110 & 93 & 3 & 2 & .2 & .2 & .01 & .03 & .12 & 21,676 \\
\hline \multirow[t]{6}{*}{2} & $6-5-92$ & 18 & 46 & 84 & 44 & 1 & 1 & .1 & .1 & .01 & .01 & .05 & 10,373 \\
\hline & $7-2-92$ & 19 & 48 & 91 & 46 & 1 & 1 & .1 & .1 & .01 & .01 & .06 & 11,060 \\
\hline & $8-25-92$ & 13 & 39 & 63 & 35 & 1 & 0 & .1 & .1 & 0 & .01 & .04 & 7,941 \\
\hline & $6-17-93$ & 20 & 49 & 94 & 47 & 1 & 1 & .1 & .1 & .01 & .01 & .06 & 11,402 \\
\hline & $6-24-93$ & 67 & 86 & 276 & 109 & 2 & 2 & .4 & .3 & .01 & .02 & .12 & 29,730 \\
\hline & $8-19-93$ & 13 & 40 & 66 & 36 & 1 & 1 & .1 & .1 & 0 & .01 & .05 & 8,292 \\
\hline \multirow[t]{6}{*}{3} & $5-22-92$ & 205 & 659 & 8,889 & 839 & 19 & 12 & 2.8 & 1.5 & .25 & .70 & 2.68 & 152,044 \\
\hline & $7-2-92$ & 53 & 350 & 2,662 & 330 & 8 & 5 & .7 & .4 & .13 & .29 & 1.17 & 52,035 \\
\hline & $10-7-92$ & 531 & 1,031 & 20,835 & 1,623 & 36 & 26 & 7.3 & 4.1 & .39 & 1.33 & 4.79 & 324,344 \\
\hline & $5-22-93$ & 98 & 466 & 4,604 & 504 & 12 & 7 & 1.3 & .7 & .18 & .43 & 1.70 & 84,697 \\
\hline & $6-17-93$ & 68 & 394 & 3,337 & 393 & 10 & 5 & .9 & .5 & .15 & .34 & 1.37 & 63,608 \\
\hline & $6-24-93$ & 207 & 663 & 8,989 & 846 & 20 & 13 & 2.8 & 1.5 & .25 & .71 & 2.70 & 153,578 \\
\hline \multirow[t]{6}{*}{4} & $6-17-92$ & 126 & 578 & $1,9 \dot{9} 7$ & 634 & 19 & 13 & 3.0 & 1.8 & .09 & .13 & .49 & 117,709 \\
\hline & $7-2-92$ & 101 & 522 & 1,604 & 545 & 16 & 11 & .4 & 1.4 & .08 & .11 & .43 & 99,061 \\
\hline & $8-25-92$ & 136 & 599 & 2,086 & 668 & 20 & 14 & 3.2 & 1.9 & .09 & .14 & .52 & 125,104 \\
\hline & $10-7-92$ & 548 & 1,153 & 7,260 & 1,755 & 487 & 39 & 13.2 & 8.4 & .17 & .34 & .22 & 379,349 \\
\hline & $5-22-95$ & 99 & 516 & 1,570 & 536 & 16 & 11 & 2.3 & 1.4 & .08 & .11 & .43 & 97,182 \\
\hline & $6-17-93$ & 53 & 384 & 894 & 347 & 11 & 7 & 1.2 & .7 & .06 & .07 & .29 & 58,908 \\
\hline \multirow[t]{6}{*}{5} & $6-5-92$ & 18 & 101 & 177 & 152 & 3 & 2 & .4 & .4 & .01 & .02 & .16 & 32,159 \\
\hline & $6-17-92$ & 28 & 125 & 263 & 207 & 5 & 3 & .6 & .6 & .02 & .03 & .21 & 45,621 \\
\hline & $7-2-92$ & 22 & 111 & 209 & 173 & 4 & 2 & .4 & .4 & .02 & .02 & .18 & 37,250 \\
\hline & $5-22-93$ & 8 & 70 & 89 & 89 & 2 & 1 & .2 & .2 & .01 & .01 & .10 & 17,341 \\
\hline & $6-17-93$ & 14 & 90 & 140 & 127 & 3 & 2 & .3 & .3 & .01 & .02 & .14 & 26,140 \\
\hline & $6-24-93$ & 53 & 168 & 464 & 321 & 7 & 5 & 1.1 & 1.1 & .02 & .04 & .31 & 75,717 \\
\hline Mean & & 95 & 308 & 2,286 & 386 & 10 & 7 & 2 & 1 & .07 & .18 & .69 & 77,962 \\
\hline
\end{tabular}

${ }^{1}$ Local regression $B O D$ models (table 19) were used to estimate $B O D$ event loads. 
Table 24. Storm statistics for Omaha, Nebraska

[Based on National Weather Service's North Omaha Airport Weather Station, 1983-92 climatological data]

\begin{tabular}{lccc}
\hline Month & $\begin{array}{c}\text { Mean duration } \\
\text { (hours) }\end{array}$ & $\begin{array}{c}\text { Mean depth of ralnfall } \\
\text { (Inches) }\end{array}$ & Number of storms \\
\hline January & 14.4 & 0.27 & 1.63 \\
February & 10.1 & .26 & 1.88 \\
March & 15.3 & .72 & 2.6 \\
April & 11.5 & .78 & 3.4 \\
May & 6.8 & .64 & 5.4 \\
June & 5.8 & .72 & 5.0 \\
July & 5.3 & .70 & 3.4 \\
August & 6.8 & .68 & 3.1 \\
September & 7.5 & .78 & 3.0 \\
October & 8.2 & .52 & 3.6 \\
November & 16.1 & .83 & 1.3 \\
December & 8.3 & .38 & 2.38 \\
Year average & 9.7 & .61 & 36.69 \\
\hline
\end{tabular}

${ }^{1}$ Periods of snowfall were not included because of the time lag between the precipitation and resulting runoff.

${ }^{2}$ Only storms with greater than 0.1 inch of rainfall were used. 

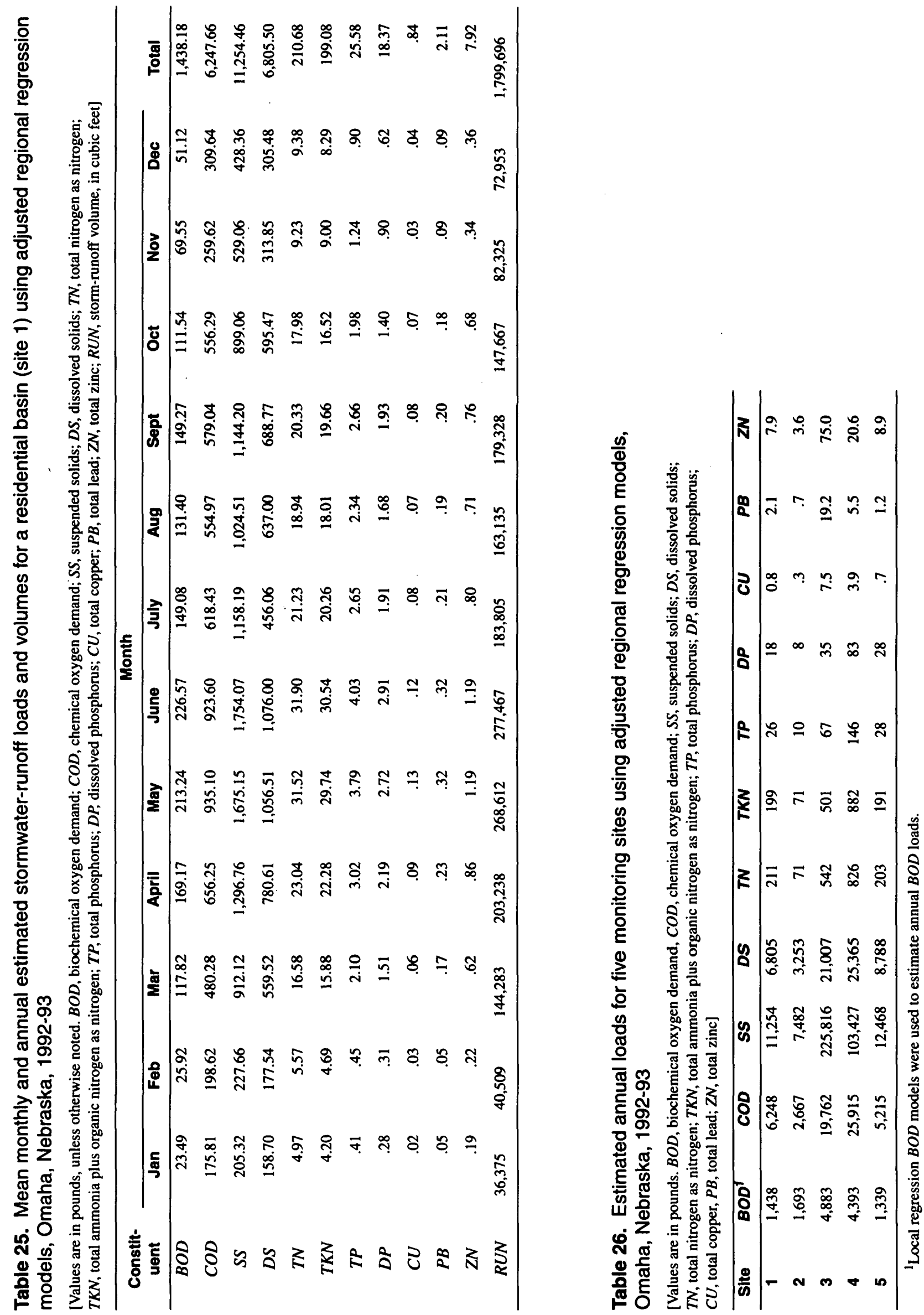


\section{SUMMARY}

The U.S. Geological Survey, in cooperation with the City of Omaha and the Papio-Missouri River Natural Resources District, Nebraska, conducted a study to describe stormwater-runoff quantity and quality from selected basins in Omaha. The study was done to meet technical data requirements for the City of Omaha to obtain a National Pollutant Discharge Elimination System (NPDES) Permit from the U.S. Environmental Protection Agency.

Stormwater-runoff quantity and quality from five sites located in residential, commercial, and industrial land-use basins in Omaha, Nebraska, were monitored from May to November 1992 and April through August 1993. The study describes the quantity and quality of stormwater discharges from selected storm sewers draining areas representative of the various urban land uses in Omaha, Nebraska. Sites 1 and 4 were representative of residential land use; sites 2 and 5 were representative of commercial land use; and site 3 was representative of industrial land use.

Grab samples and flow-weighted composite samples were collected at each of the five sites during six storms and were analyzed for 147 chemical, physical, and biological characteristics. Total rainfall, runoff volume, runoff-rainfall ratio, peak discharge, rainfall and runoff duration, and number of dry hours between storms were calculated and compiled. Mean rainfall during the study was slightly greater in the residential basins ( 0.60 inch) than in the commercial ( 0.45 inch) and industrial ( $0.46 \mathrm{inch}$ ) basins. However, mean runoff-rainfall ratio for the commercial $(0.38)$ and industrial $(0.32)$ basins was more than twice the runoff-rainfall ratio of the residential basins $(0.15)$.

Grab samples were collected within the first 30 minutes of each storm. The samples represented the storm's first-flush effects. These samples were used to determine $\mathrm{pH}$, water temperature, residual chlorine, volatile organic compounds (VOCs), cyanide, total phenols, biological oxygen demand, fecal coliform and fecal streptococcus bacteria, and oil and grease.

To estimate mean water quality in the study area, flow-weighted samples were composited from discrete samples collected by automatic samplers during the first 3 hours of a storm and were analyzed for a variety of constituents and physical properties.
The constituents and properties included acid and base/neutral organic compounds, pesticides and polychlorinated biphenyls (PCBs), trace elements, chemical oxygen demand, suspended solids, dissolved solids, nutrients, major ions, alkalinity, $\mathrm{pH}$, specific conductance, and total organic carbon.

Thirty-eight of the 147 constituents were detected in the basins, and eight constituents exceeded the U.S. Environmental Agency's Maximum Contaminant Levels (USEPA MCLs) for drinking water in at least one sample. Analytical results indicated that four VOCs-chloroform, dichlorobromomethane, methyl chloride, and toluene-were detected. Toluene was detected only at the residential sites ( 1 and 4 ).

Of the 10 acid organic compounds analyzed, none were detected in stormwater-runoff samples, whereas 12 of 45 base/neutral organic compounds were detected in 45 percent of the samples. The four most commonly detected compounds were bis(2-ethylhexyl)phthalate, fluoranthene, phenanthrene, and pyrene. Although more base/neutral organic compounds were detected in samples collected from the residential basins, concentrations were less than the USEPA MCLs for drinking water. Eleven base/neutral organic compounds with concentrations ranging from 9 to $150 \mu \mathrm{g} / \mathrm{L}$ were detected in a commercial basin (site 5) during a storm-runoff event May 22, 1993. This was not a typical sampling event because 11 of the 12 base/neutral compounds were detected. Concentrations of six of the compounds exceeded USEPA MCLs for drinking water.

Only 6 of 21 pesticides were detected in samples collected in the study area. Concentrations of pesticides ranged from $0.1 \mu \mathrm{g} / \mathrm{L}$ (chlordane and 4,4-DDT) to $13 \mu \mathrm{g} / \mathrm{L}(2,4-\mathrm{D})$ in the study area, none of which exceeded the USEPA MCLs for drinking water. PCB 1242 and PCB 1254 were detected in two samples collected from a residential basin (site 4), and PCB 1254 was detected in one sample collected from the industrial basin (site 3). PCB concentrations were less than the MCLs established by the USEPA for drinking water.

Nine of the 14 trace elements were detected in samples collected in the study area. Concentrations of trace elements did not exceed USEPA MCLs for drinking water with the exception of total beryllium and total lead. Total lead also exceeded treatment action levels established by USEPA in drinking 
water. Trace-element concentrations in samples collected from the industrial basin were, in general, greater than concentrations in samples collected from the residential and commercial basins; total beryllium and total mercury were the only exceptions. Median concentrations of lead in samples collected from the industrial basin $(72 \mu \mathrm{g} / \mathrm{L})$ were about 6 times greater than those collected in the residential and commercial basins. Median concentrations of total copper $(27 \mu \mathrm{g} / \mathrm{L})$, total nickel $(17 \mu \mathrm{g} / \mathrm{L})$, and total zinc $(285 \mu \mathrm{g} / \mathrm{L})$ were about 3 times greater in samples collected in the industrial basin than those collected in the residential and commercial basins.

Median concentrations of BOD $(19 \mathrm{mg} / \mathrm{L})$ and COD $(115 \mathrm{mg} / \mathrm{L})$ in the industrial basin were about 1.5 to 2 times greater than in the residential and commercial basins. Bacterial concentrations ranged from 200 to 110,000 colonies $/ 100 \mathrm{~mL}$. Bacteria concentrations in samples collected in the residential land-use basins were much greater than in samples collected from the commercial and industrial basins.

Concentrations of total nitrogen as $\mathrm{N}$, total ammonia plus organic nitrogen as $\mathrm{N}$, total phosphorus, and dissolved phosphorus were detected in all stormwater samples. Concentrations of total nitrogen ranged from $0.7 \mathrm{mg} / \mathrm{L}$ to $3.8 \mathrm{mg} / \mathrm{L}$ and total phosphorus ranged from $0.09 \mathrm{mg} / \mathrm{L}$ to $0.66 \mathrm{mg} / \mathrm{L}$. Median concentrations of total nitrogen and total ammonia plus organic nitrogen $(2.7 \mathrm{mg} / \mathrm{L}$ and $1.7 \mathrm{mg} / \mathrm{L}$ ) were greater in samples collected from the industrial basin than in samples collected from the residential $(2.3 \mathrm{mg} / \mathrm{L}$ and $1.5 \mathrm{mg} / \mathrm{L})$ and commercial $(1.7 \mathrm{mg} / \mathrm{L}$ and $1.0 \mathrm{mg} / \mathrm{L})$ basins. Median concentrations of total phosphorus were greater in samples collected from the residential basins $(0.3 \mathrm{mg} / \mathrm{L})$ than in samples collected from the commercial $(0.16 \mathrm{mg} / \mathrm{L})$ and industrial $(0.26 \mathrm{mg} / \mathrm{L})$ basins. Median concentrations of dissolved phosphorus ranged from 0.11 to $0.19 \mathrm{mg} / \mathrm{L}$.

The USEPA regulations for NPDES require a city-wide (cumulative) annual load calculation for 12 constituents: biological oxygen demand, chemical oxygen demand, suspended solids, dissolved solids, total nitrogen as $\mathrm{N}$, total ammonia plus organic nitrogen as $\mathrm{N}$, total phosphorus, dissolved phosphorus, total cadmium, total copper, total lead, and total zinc. Constituent loads were computed for the 12 constituents by direct computation of observed data for six storms at each of the five sites. The loads varied greatly depending on the site and rainfall event. In general, the greater the runoff volume for a specific basin, the greater the loads that were produced.

Annual stormwater-runoff constituent loads were estimated for 11 constituents-biochemical oxygen demand, chemical oxygen demand, suspended solids, dissolved solids, total nitrogen as $\mathrm{N}$, total ammonia plus organic nitrogen as $\mathrm{N}$, total phosphorus, dissolved phosphorus, total copper, total lead, and total zinc-for each site using the USEPA simple method, and by multiple-regression models. An equation was not derived for total cadmium because cadmium was detected only in samples collected from the industrial basin (site 3).

Although local regression models were more appropriate in terms of the amount of explained variation ( $R^{2}$ ranged from 0.60 to 0.83 percent), the number of storms used to derive these regression equations was limited to 30 . Because of the small number of samples used, the associated confidence level was not high. Thus, modified regression models with a larger sample size were developed by adjusting regional models with local monitoring data.

The modified 10 constituent load equations, stormwater-runoff regression models, and a local biological oxygen demand regression equation can be applied to gaged and ungaged outfalls and basins in the City of Omaha.

\section{SELECTED REFERENCES}

Bartlett, P.A., 1975, Soil survey of Douglas and Sarpy Counties, Nebraska: U.S. Department of Agriculture, Soil Conservation Service, 79 p.

City of Omaha, 1992, Stormwater discharge permit application, Part 1: Omaha, Nebraska, Public Works Department, City of Omaha, 4205 p.

Draper, N.R., and Smith, Harry, 1981, Applied regression analysis (2d. ed.): New York, John Wiley and Sons, $709 \mathrm{p}$.

Driver, N.E., and Tasker, G.D., 1990, Techniques for estimation of storm-runoff loads, volumes, and selected constituent concentrations in urban watersheds in the United States: U.S. Geological Survey Water-Supply Paper 2363, 44 p.

Ferguson, R.I., 1986, River loads underestimated by rating curves: Water Resources Research, v. 22, no. 1, p. $74-76$. 
Fishman, M.J., and Friedman, L.C., eds., 1989, Methods for determination of inorganic substances in water and fluvial sediments: U.S. Geological Survey Techniques of WaterResources Investigations, book 5, chap. A1, 545 p.

Franson, M.A.H., ed., 1989, Standard methods for the examination of water and wastewater:

Washington, D. C., American Public Health Association, variable pagination.

Friedman, L.C., and Fishman, M.J., 1982, Quality assurance practices for the chemical and biological analyses of water and fluvial sediments: U.S. Geological Survey Techniques of WaterResources Investigations, book 5, chap. A6, 181 p.

Grant, D.M., 1991, Isco open channel flow measurement handbook ( $3 \mathrm{~d}$ ed.): Lincoln, Nebraska, Isco, 356 p.

Hem, J.D., 1985, Study and interpretation of the chemical characteristics of natural water ( $3 \mathrm{~d}$ ed.): U.S. Geological Survey Water-Supply Paper 2254, 263 p.

Hoos, A.B., and Sisolak, J.K., 1993, Procedures for adjusting regional regression models of urbanrunoff quality using local data: U.S. Geological Survey Open-File Report 93-99, 39 p.

Miller, R.D., 1964, Geology of the Omaha-Council Bluffs area, Nebraska-Iowa: U.S. Geological Survey Professional Paper 472, 70 p.

Oltmann, R.N., and Shulters, M.V., 1989, Rainfall and runoff quantity and quality characteristics of four urban land-use basins in Fresno, California, October 1981 to April 1983: U.S. Geological Survey Water-Supply Paper 2335, 114 p.

SAS Institute, Inc., 1982, SAS user's guide-statistics: Cary, North Carolina, SAS Institute, Inc., 584 p.

Sax, N.I., and Lewis, R.J., 1987, Hawley's condensed chemical dictionary (11th ed.): New York, Van Nostrand Reinhold, 1288 p.

U.S. Environmental Protection Agency, 1983, Results of the nationwide urban runoff program: Washington, D.C., Water Planning Division, U.S. Environmental Protection Agency, 24 p.
1988, Maximum contaminant levels (subpart B of part 141, National primary drinking water regulations): U.S. Code of Federal Regulations, Title 40, parts 100 to 149 , revised as of July 1 , 1988, p. $530-533$.

1990, National pollutant discharge elimination system permit application regulations for stormwater discharges; final rule: U.S. Federal Register, v. 55, no. 222, p. 47989-48091.

1991, Guidance manual for the preparation of part 1 of the NPDES permit application for discharges from municipal separate storm sewer systems: U.S. Environmental Protection Agency.

1992a, Guidance manual for the preparation of Part 2 of the NPDES permit applications for discharges from municipal separate storm sewer systems: U.S. Environmental Protection Agency.

1992b, NPDES stormwater sampling guidance document: $121 \mathrm{p}$.

1996, Drinking water regulations and health advisories: Washington, D.C., Office of Water, U.S. Environmental Protection Agency, EPA 8-22-R-96-001.

Ward, J.R., and Harr, C. Albert., eds., 1990, Methods for collection and processing of surface-water and bed-material samples for physical and chemical analyses: U.S. Geological Survey Open-File Report 90-140, 71 p.

Wershaw, R.L., Fishman, M.J., Grabbe, R.R., and Lowe, L.E., 1987, Methods for the determination of organic substances in water and fluvial sediments: U.S. Geological Survey Techniques of Water-Resources Investigations, book 5, chap. A3, $80 \mathrm{p}$. 
. 


\section{APPENDIX A-STORM RAINFALL AND RUNOFF CHARACTER-}

ISTICS FOR FIVE SITES, OMAHA, NEBRASKA, 1992-93 
Table 2. Storm rainfall and runoff characteristics for five sites, Omaha, Nebraska, 1992-93

[See figure 2 for site locations. Total runoff volume means observed runoff volume, in inches, on the contributing drainage area. in., inches; $\mathrm{ft}^{3} / \mathrm{s}$, cubic feet per second; min, minutes; hrs, hours; --, no data available]

\begin{tabular}{|c|c|c|c|c|c|c|c|c|c|c|}
\hline \multicolumn{4}{|c|}{ Storm duration } & \multirow{3}{*}{$\begin{array}{c}\text { Rainfall, } \\
\text { total } \\
\text { (in.) }\end{array}$} & \multirow{3}{*}{$\begin{array}{c}\text { Runoff } \\
\text { volume, } \\
\text { total } \\
\text { (in.) }\end{array}$} & \multirow{3}{*}{$\begin{array}{c}\text { Runoff- } \\
\text { rainfall } \\
\text { ratio }\end{array}$} & \multirow{3}{*}{$\begin{array}{c}\text { Peak } \\
\text { dis- } \\
\text { charge } \\
\left(\mathrm{ft}^{3} / \mathrm{s}\right)\end{array}$} & \multirow{3}{*}{$\begin{array}{c}\text { Rainfall } \\
\text { dura- } \\
\text { tion } \\
\text { (min) }\end{array}$} & \multirow{3}{*}{$\begin{array}{c}\text { Runoff } \\
\text { dura- } \\
\text { tion } \\
\text { (min) }\end{array}$} & \multirow{3}{*}{$\begin{array}{c}\text { Time } \\
\text { since } \\
\text { previous } \\
\text { storm } \\
\text { (hrs) }\end{array}$} \\
\hline \multicolumn{2}{|c|}{ First rainfall } & \multicolumn{2}{|c|}{ End of runoff } & & & & & & & \\
\hline Date & Time & Date & Time & & & & & & & \\
\hline \multicolumn{11}{|c|}{ Residential, single-dwelling (site 1) } \\
\hline${ }^{1} 05-22-92$ & 1618 & $05-22-92$ & 1734 & 0.14 & 0.002 & 0.014 & 1.3 & -- & 60 & -- \\
\hline${ }^{1} 05-25-92$ & 0405 & $05-25-92$ & 1010 & .21 & .010 & .046 & 1.3 & 329 & 360 & 59.8 \\
\hline${ }^{2} 05-31-92$ & 2041 & $06-01-92$ & 1530 & .16 & .015 & .092 & 1.5 & 1,092 & 1,020 & 160.6 \\
\hline${ }^{1} 06-05-92$ & 2006 & $06-05-92$ & 2318 & .35 & .009 & .026 & 2.2 & 162 & 180 & 119.4 \\
\hline${ }^{1} 06-17-92$ & 0000 & $06-17-92$ & 0145 & .51 & .015 & .029 & 24.3 & 29 & 105 & 267.9 \\
\hline${ }^{1} 06-24-92$ & 1006 & $06-24-92$ & 1148 & .15 & .003 & .020 & 1.5 & 81 & 60 & 178.1 \\
\hline${ }^{1} 07-02-92$ & 0716 & $07-02-92$ & 1000 & .41 & .004 & .010 & 2.0 & 115 & 160 & 189.2 \\
\hline${ }^{1} 07-04-92$ & 2218 & $07-05-92$ & 0200 & .33 & .003 & .010 & 2.5 & 98 & 225 & 63.0 \\
\hline${ }^{3} 07-05-92$ & 0621 & $07-05-92$ & 1400 & .44 & .013 & .029 & 1.5 & 294 & 480 & 8.1 \\
\hline${ }^{1} 07-12-92$ & 0323 & $07-12-92$ & 0830 & 1.89 & .101 & .053 & 101.1 & 325 & 300 & 165.0 \\
\hline${ }^{1} 07-12-92$ & 2143 & $07-13-92$ & 1100 & 1.09 & .027 & .025 & 9.6 & 611 & 720 & 18.3 \\
\hline${ }^{1} 07-30-92$ & 0040 & $07-30-92$ & 0430 & .80 & .016 & .020 & 2.8 & 270 & 220 & 411.0 \\
\hline${ }^{1} 08-02-92$ & 0410 & $08-02-92$ & 0900 & .71 & .010 & .014 & 11.8 & 140 & 220 & 75.5 \\
\hline${ }^{1} 08-07-92$ & 0320 & $08-07-92$ & 0800 & 1.73 & .175 & .101 & 248.4 & 90 & 279 & 119.2 \\
\hline${ }^{1} 08-12-92$ & 0520 & $08-12-92$ & 0605 & .09 & .001 & .010 & 1.6 & 90 & 40 & 122.0 \\
\hline${ }^{1} 08-25-92$ & 0855 & $08-25-92$ & 1025 & .67 & .011 & .015 & 5.1 & 350 & 150 & 315.6 \\
\hline${ }^{1} 09-01-92$ & 1320 & $09-01-92$ & 2210 & .17 & .010 & .059 & 3.9 & 500 & 515 & 172.4 \\
\hline${ }^{1} 09-02-92$ & 0120 & $09-02-92$ & 0735 & .54 & .031 & .057 & 4.9 & 185 & 370 & 12.0 \\
\hline${ }^{1} 09-05-92$ & 0710 & $09-05-92$ & 1000 & .11 & .012 & .110 & 5.2 & 75 & 120 & 77.8 \\
\hline${ }^{\prime} 09-09-92$ & 0555 & $09-09-92$ & 1150 & .05 & .004 & .080 & 3.5 & 35 & 85 & 94.8 \\
\hline${ }^{1} 09-14-92$ & 0525 & $09-14-92$ & 1400 & 1.57 & .205 & .132 & 112.2 & 430 & 480 & 119.5 \\
\hline${ }^{4} 09-15-92$ & 0840 & $09-15-92$ & 1000 & .06 & .009 & .150 & 14.8 & 10 & 90 & 27.2 \\
\hline${ }^{1} 09-17-92$ & 2210 & $09-18-92$ & 0130 & .41 & .052 & .127 & 99.2 & 110 & 190 & 61.5 \\
\hline${ }^{1} 09-26-92$ & 0015 & $09-26-92$ & 0415 & .32 & .033 & .103 & 9.9 & 300 & 230 & 194.1 \\
\hline${ }^{1} 10-07-92$ & 1705 & $10-08-92$ & 1445 & 2.32 & .413 & .178 & 31.7 & 1,119 & 1,300 & 280.8 \\
\hline${ }^{1} 10-31-92$ & 1711 & $10-31-92$ & 1830 & .14 & .021 & .150 & -- & -- & -- & 576.6 \\
\hline${ }^{1} 05-06-93$ & 1513 & $05-06-93$ & 2300 & .18 & .100 & .556 & 53.9 & 420 & 300 & -- \\
\hline${ }^{1} 05-07-93$ & 2246 & $05-09-93$ & 0000 & .51 & .043 & .084 & 8.6 & 1,440 & 1,515 & 31.6 \\
\hline${ }^{1} 05-09-93$ & 2018 & $05-10-93$ & 1500 & .87 & .217 & .250 & 17.6 & 1,110 & 1,122 & 45.5 \\
\hline${ }^{1} 05-11-93$ & 0010 & $05-11-93$ & 0300 & .10 & .013 & .130 & 9.4 & 150 & 90 & 27.9 \\
\hline
\end{tabular}


Table 2. Storm rainfall and runoff characteristics for five sites, Omaha, Nebraska, 1992-93--Continued

\begin{tabular}{|c|c|c|c|c|c|c|c|c|c|c|}
\hline \multicolumn{4}{|c|}{ Storm duration } & \multirow{3}{*}{$\begin{array}{c}\text { Rainfall, } \\
\text { total } \\
\text { (In.) }\end{array}$} & \multirow{3}{*}{$\begin{array}{c}\text { Runoff } \\
\text { volume, } \\
\text { total } \\
\text { (in.) }\end{array}$} & \multirow{3}{*}{$\begin{array}{c}\text { Runoff- } \\
\text { rainfall } \\
\text { ratio }\end{array}$} & \multirow{3}{*}{$\begin{array}{c}\text { Peak } \\
\text { dis- } \\
\text { charge } \\
\left(\mathrm{ft}^{3} / \mathrm{s}\right)\end{array}$} & \multirow{3}{*}{$\begin{array}{c}\text { Rainfall } \\
\text { dura- } \\
\text { tion } \\
\text { (min) }\end{array}$} & \multirow{3}{*}{$\begin{array}{c}\text { Runoff } \\
\text { dura- } \\
\text { tion } \\
\text { (min) }\end{array}$} & \multirow{3}{*}{$\begin{array}{c}\text { Time } \\
\text { since } \\
\text { previous } \\
\text { storm } \\
\text { (hrs) }\end{array}$} \\
\hline First rai & ifall & End of & unoff & & & & & & & \\
\hline Date & Time & Date & Time & & & & & & & \\
\hline \multicolumn{11}{|c|}{ Residential, single-dwelling (site 1)-Continued } \\
\hline${ }^{1} 05-11-93$ & 1524 & $05-11-93$ & 1800 & 0.12 & 0.021 & 0.173 & 5.8 & 81 & 150 & 15.2 \\
\hline${ }^{1} 05-19-93$ & 1005 & $05-19-93$ & 1200 & .04 & .007 & .187 & 5.7 & 90 & 105 & 186.7 \\
\hline${ }^{1} 05-22-93$ & 0525 & $05-22-93$ & 1100 & .18 & .058 & .321 & 30.7 & 175 & 300 & 67.3 \\
\hline${ }^{1} 05-23-93$ & 0220 & $05-23-93$ & 0600 & .20 & .046 & .229 & 12.1 & 105 & 210 & 20.9 \\
\hline${ }^{\prime} 05-30-93$ & 0546 & $05-30-93$ & 0730 & .03 & .002 & .060 & 1.8 & 99 & 90 & 171.4 \\
\hline${ }^{1} 06-01-93$ & 1325 & $06-02-93$ & 0200 & .15 & .027 & .182 & 9.9 & 531 & 240 & 55.7 \\
\hline${ }^{\prime} 06-03-93$ & 1645 & $06-04-93$ & 1200 & .50 & .108 & .216 & 13.8 & 960 & 960 & 51.3 \\
\hline${ }^{1} 06-06-93$ & 0335 & $06-06-93$ & 1300 & .35 & .093 & .280 & 120.9 & 420 & 600 & 58.8 \\
\hline${ }^{\prime} 06-11-93$ & 1930 & $06-12-93$ & 0300 & .42 & .099 & .237 & 110.0 & 306 & 900 & 134.0 \\
\hline${ }^{1} 06-13-93$ & 0340 & $06-13-93$ & 1900 & .43 & .150 & .349 & 92.8 & 405 & 960 & 34.1 \\
\hline${ }^{1} 06-17-93$ & 1755 & $06-17-93$ & 2400 & .28 & .032 & .114 & 9.2 & 147 & 360 & 110.3 \\
\hline${ }^{2} 06-18-93$ & 0240 & $06-18-93$ & 2000 & 1.71 & .320 & .187 & 271.6 & 810 & 660 & 8.8 \\
\hline${ }^{1} 06-19-93$ & 0610 & $06-19-93$ & 1200 & .12 & .009 & .073 & 33.1 & 186 & 360 & 27.5 \\
\hline${ }^{1} 06-23-93$ & 0325 & $06-23-93$ & 0900 & .01 & .006 & .551 & 1.9 & 300 & 360 & 93.3 \\
\hline${ }^{1} 06-24-93$ & 0150 & $06-24-93$ & 1000 & .88 & .124 & .141 & 88.3 & 330 & 480 & 22.4 \\
\hline${ }^{1} 06-28-93$ & 0100 & $06-28-93$ & 1200 & .73 & .109 & .149 & 50.5 & 510 & 600 & 95.2 \\
\hline${ }^{1} 06-30-93$ & 1750 & $07-01-93$ & 2000 & .35 & .038 & .107 & 60.5 & 115 & 130 & 60.6 \\
\hline${ }^{\prime} 07-04-93$ & 0130 & $07-04-93$ & 0700 & .09 & .010 & .111 & 9.0 & 150 & 360 & 83.9 \\
\hline${ }^{1} 07-05-93$ & 0445 & $07-05-93$ & 1600 & .77 & .095 & .124 & 12.7 & 585 & 675 & 24.3 \\
\hline${ }^{1} 07-07-93$ & 0530 & $07-07-93$ & 1100 & .35 & .049 & .140 & 7.6 & 221 & 300 & 51.7 \\
\hline${ }^{1} 07-08-93$ & 0425 & $07-08-93$ & 0900 & .47 & .081 & .171 & 90.4 & 117 & 300 & 22.9 \\
\hline${ }^{1} 07-08-93$ & 1930 & $07-09-93$ & 0600 & .41 & .072 & .175 & 19.6 & 480 & 660 & 15.1 \\
\hline${ }^{1} 07-10-93$ & 0405 & $07-10-93$ & 1430 & .17 & .003 & .020 & 2.3 & 150 & 150 & 31.7 \\
\hline${ }^{\prime} 07-11-93$ & 0125 & $07-11-93$ & 0600 & .33 & .105 & .317 & 159.2 & 15 & 300 & 22.3 \\
\hline${ }^{2} 07-13-93$ & 0430 & $07-13-93$ & 1800 & 1.60 & .150 & .094 & 169.3 & 105 & 360 & 51.1 \\
\hline${ }^{1} 07-13-93$ & 2105 & $07-14-93$ & 0600 & .43 & .014 & .032 & 4.5 & 40 & 180 & 16.6 \\
\hline${ }^{1} 07-17-93$ & 1340 & $07-17-93$ & 0700 & .25 & .024 & .094 & 5.0 & 528 & 660 & 88.6 \\
\hline${ }^{1} 07-20-93$ & 0915 & $07-20-93$ & 1300 & .30 & .034 & .114 & 18.9 & 192 & 240 & 67.6 \\
\hline${ }^{2} 07-21-93$ & 1125 & $07-22-93$ & 1900 & 3.06 & .780 & .255 & 579.5 & 1,350 & 1,860 & 26.2 \\
\hline${ }^{2} 07-24-93$ & 0550 & $07-25-93$ & 1800 & 1.82 & .880 & .484 & 587 & 156 & 420 & 18.3 \\
\hline
\end{tabular}


Table 2. Storm rainfall and runoff characteristics for five sites, Omaha, Nebraska, 1992-93--Continued

\begin{tabular}{|c|c|c|c|c|c|c|c|c|c|c|}
\hline \multicolumn{4}{|c|}{ Storm duration } & \multirow{3}{*}{$\begin{array}{c}\text { Rainfall, } \\
\text { total } \\
\text { (in.) }\end{array}$} & \multirow{3}{*}{$\begin{array}{c}\text { Runoff } \\
\text { volume, } \\
\text { total } \\
\text { (in.) }\end{array}$} & \multirow{3}{*}{$\begin{array}{c}\text { Runoff- } \\
\text { rainfall } \\
\text { ratio }\end{array}$} & \multirow{3}{*}{$\begin{array}{l}\text { Peak } \\
\text { dis- } \\
\text { charge } \\
\left(\mathrm{ft}^{3} / \mathrm{s}\right)\end{array}$} & \multirow{3}{*}{$\begin{array}{c}\text { Rainfall } \\
\text { dura- } \\
\text { tion } \\
\text { (min) }\end{array}$} & \multirow{3}{*}{$\begin{array}{c}\text { Runoff } \\
\text { dura- } \\
\text { tion } \\
\text { (min) }\end{array}$} & \multirow{3}{*}{$\begin{array}{c}\text { Time } \\
\text { since } \\
\text { previous } \\
\text { storm } \\
\text { (hrs) }\end{array}$} \\
\hline First rai & & End of & inoff & & & & & & & \\
\hline Date & Time & Date & Time & & & & & & & \\
\hline \multicolumn{11}{|c|}{ Commercial (site 2) } \\
\hline $05-22-92$ & 1407 & $05-23-92$ & 0900 & 0.59 & 0.371 & 0.629 & 21.8 & 126 & 1,080 & -- \\
\hline $05-25-92$ & 0422 & $05-25-92$ & 1400 & .21 & .148 & .703 & 2.5 & 121 & 570 & 62.3 \\
\hline $05-31-92$ & 2101 & $06-02-92$ & 0100 & .19 & .141 & .744 & .6 & 70 & 1,680 & 160.7 \\
\hline${ }^{1} 06-05-92$ & 2010 & $06-06-92$ & 0130 & .35 & .193 & .552 & 7.4 & 136 & 1,200 & 119.2 \\
\hline $06-14-92$ & 1138 & $06-14-92$ & 1600 & .12 & .086 & .714 & 12.8 & 102 & 300 & 207.5 \\
\hline $06-16-92$ & 2357 & $06-17-92$ & 0600 & .38 & .244 & .642 & 26.4 & 44 & 360 & 60.3 \\
\hline $06-24-92$ & 1020 & $06-24-92$ & 1500 & .11 & .057 & .520 & 2.4 & 59 & 300 & 78.4 \\
\hline $07-02-92$ & 0722 & $07-02-92$ & 1900 & .30 & .215 & .717 & 27.7 & 38 & 780 & 189.0 \\
\hline $07-04-92$ & 2150 & $07-05-92$ & 1600 & .70 & .556 & .794 & 25.3 & 183 & 1,680 & 62.5 \\
\hline $07-07-92$ & 0334 & $07-07-92$ & 1100 & .07 & .038 & .542 & 2.1 & 37 & 480 & 53.7 \\
\hline $07-11-92$ & 0912 & $07-11-92$ & 2300 & .82 & .619 & .755 & 22.4 & 136 & 840 & 101.6 \\
\hline $07-12-92$ & 0330 & $07-13-92$ & 1700 & 2.55 & 2.036 & .799 & 51.7 & 410 & 2,280 & 18.3 \\
\hline $07-18-92$ & 2304 & $07-19-92$ & 1100 & 1.49 & 1.044 & .700 & 55.8 & 39 & 720 & 163.6 \\
\hline $07-21-92$ & 2355 & $07-22-92$ & 1600 & .62 & .476 & .767 & 28.2 & 123 & 960 & 72.8 \\
\hline $07-24-92$ & 1345 & $07-25-92$ & 0900 & .50 & .435 & .869 & 48.3 & 41 & 1,200 & 61.8 \\
\hline $07-25-92$ & 1800 & $07-26-92$ & 0300 & .29 & .263 & .907 & 31.3 & 5 & 540 & 28.3 \\
\hline $07-28-92$ & 0545 & $07-28-92$ & 2100 & .52 & .318 & .611 & 23.4 & 52 & 960 & 59.7 \\
\hline $07-30-92$ & 0040 & $07-30-92$ & 1600 & 1.10 & 1.015 & .923 & 42.0 & 157 & 960 & 42.9 \\
\hline $08-02-92$ & 0410 & $08-02-92$ & 1600 & .72 & .639 & .888 & 39.8 & 65 & 720 & 75.5 \\
\hline 08-04-92 & 2050 & $08-04-92$ & 2300 & .01 & .001 & .105 & .1 & 1 & 120 & 64.7 \\
\hline $08-07-92$ & 0320 & 08-07-92 & 1400 & 1.76 & 1.073 & .609 & 57.9 & 90 & 660 & 54.5 \\
\hline $08-12-92$ & 0520 & $08-12-92$ & 0625 & .05 & .002 & .036 & .1 & 36 & 30 & 122.0 \\
\hline $08-25-92$ & $0855^{\circ}$ & $08-25-92$ & 1245 & .21 & .013 & .064 & 3.9 & 127 & 220 & 315.6 \\
\hline${ }^{1} 09-01-92$ & 1325 & $09-01-92$ & 1930 & .17 & .022 & .129 & 1.7 & 285 & 150 & 172.5 \\
\hline${ }^{1} 09-02-92$ & 0000 & $09-02-92$ & 0530 & .54 & .211 & .391 & 16.6 & 265 & 300 & 10.6 \\
\hline${ }^{1} 09-02-92$ & 2130 & $09-02-92$ & 2200 & .04 & .016 & .400 & 3.1 & 1 & 30 & 21.5 \\
\hline $09-05-92$ & 0710 & $09-05-92$ & 0945 & .52 & .096 & .185 & 9.0 & 75 & 155 & 57.7 \\
\hline $09-05-92$ & 1630 & $09-05-92$ & 1705 & .04 & .004 & .112 & .7 & 1 & 35 & 9.3 \\
\hline $05-06-93$ & 1513 & $05-06-93$ & 2400 & .84 & .730 & .870 & 37.1 & 420 & 525 & -- \\
\hline $05-07-93$ & 2246 & $05-08-93$ & 2400 & .73 & - & -- & 8.1 & 1,440 & 1,500 & 31.6 \\
\hline
\end{tabular}


Table 2. Storm rainfall and runoff characteristics for five sites, Omaha, Nebraska, 1992-93--Continued

\begin{tabular}{|c|c|c|c|c|c|c|c|c|c|c|}
\hline \multicolumn{4}{|c|}{ Storm duration } & \multirow{3}{*}{$\begin{array}{l}\text { Rainfall, } \\
\text { total } \\
\text { (In.) }\end{array}$} & \multirow{3}{*}{$\begin{array}{c}\text { Runoff } \\
\text { volume, } \\
\text { total } \\
\text { (in.) }\end{array}$} & \multirow{3}{*}{$\begin{array}{c}\text { Runoff- } \\
\text { rainfall } \\
\text { ratio }\end{array}$} & \multirow{3}{*}{$\begin{array}{c}\text { Peak } \\
\text { dis- } \\
\text { charge } \\
\left(\mathrm{ft}^{3} / \mathrm{s}\right)\end{array}$} & \multirow{3}{*}{$\begin{array}{l}\text { Rainfall } \\
\text { dura- } \\
\text { tion } \\
\text { (min) }\end{array}$} & \multirow{3}{*}{$\begin{array}{l}\text { Runoff } \\
\text { dura- } \\
\text { tion } \\
\text { (min) }\end{array}$} & \multirow{3}{*}{$\begin{array}{c}\text { Time } \\
\text { since } \\
\text { previous } \\
\text { storm } \\
\text { (hrs) }\end{array}$} \\
\hline \multicolumn{2}{|c|}{ First rainfall } & \multicolumn{2}{|c|}{ End of runoff } & & & & & & & \\
\hline Date & Time & Date & Time & & & & & & & \\
\hline \multicolumn{11}{|c|}{ Commercial (site 2)-Continued } \\
\hline 05-09-93 & 2018 & $05-10-93$ & 1630 & .92 & -- & -- & 9.2 & 1,110 & 1,230 & 45.5 \\
\hline $05-11-93$ & 0010 & $05-11-93$ & 0400 & .10 & -- & -- & 5.1 & 150 & 210 & 27.9 \\
\hline 05-11-93 & 1522 & 05-11-93 & 2000 & .14 & -- & -- & 3.7 & 113 & 270 & 15.2 \\
\hline $05-19-93$ & 1005 & 05-19-93 & 1400 & .03 & .010 & .333 & .3 & 70 & 240 & 186.7 \\
\hline $05-22-93$ & 0520 & $05-22-93$ & 1100 & .32 & -- & -- & 19.2 & 115 & 360 & 67.3 \\
\hline 05-23-93 & 0220 & $05-23-93$ & 0600 & 0.27 & -- & -- & 19.8 & 95 & 240 & 21.0 \\
\hline $05-30-93$ & 0150 & $05-30-93$ & 1000 & .03 & .008 & -- & .283 & 10 & 480 & 167.5 \\
\hline $06-01-93$ & 1350 & $06-02-93$ & 0300 & .28 & .251 & .895 & 6.8 & 120 & 1,620 & 60.0 \\
\hline 06-03-93 & 2100 & $06-04-93$ & 1300 & .70 & -- & -- & 11.0 & 260 & 960 & 55.2 \\
\hline $06-06-93$ & 0335 & $06-06-93$ & 1400 & .43 & .415 & .965 & 21.1 & 55 & 660 & 54.6 \\
\hline $06-11-93$ & 1745 & $06-12-93$ & 0300 & .41 & .273 & .665 & 13.3 & 315 & 600 & 134.2 \\
\hline $06-13-93$ & 0340 & $06-1 \cdot 3-93$ & 1800 & .81 & .789 & .974 & 24.6 & 255. & 900 & 33.9 \\
\hline $06-17-93$ & 1815 & $06-17-93$ & 2200 & .31 & .195 & .629 & 10.7 & 100 & 360 & 110.6 \\
\hline $06-18-93$ & 0315 & $06-18-93$ & 0900 & .21 & .196 & .934 & 2.8 & 90 & 420 & 9.0 \\
\hline 06-18-93 & 1500 & $06-18-93$ & 2300 & 1.24 & .841 & .679 & 73.0 & 85 & 480 & 11.8 \\
\hline $06-19-93$ & 0635 & $06-19-93$ & 1200 & .08 & .058 & .725 & 1.2 & 75 & 420 & 15.6 \\
\hline $06-23-93$ & 0330 & $06-23-93$ & 1100 & .08 & .016 & .194 & .5 & 45 & 360 & 92.9 \\
\hline 06-24-93 & 0155 & $06-24-93$ & 1200 & .87 & .656 & .754 & 27.5 & 230 & 600 & 22.4 \\
\hline $06-28-93$ & 0105 & $06-28-93$ & 1300 & .96 & .609 & .635 & 24.1 & 210 & 720 & 95.2 \\
\hline 06-30-93 & 1350 & $06-30-93$ & 2400 & .30 & .193 & .643 & 15.0 & 55 & 420 & 60.8 \\
\hline 07-04-93 & 0135 & $07-04-93$ & 0700 & .12 & .042 & .347 & 3.9 & 40 & 360 & 83.8 \\
\hline 07-05-93 & 0405 & $07-05-93$ & 1500 & .63 & .438 & .695 & 5.0 & 275 & 660 & 26.5 \\
\hline 07-07-93 & 0545 & $07-07-93$ & 1400 & .37 & .244 & .658 & 3.4 & 205 & 480 & 49.7 \\
\hline $07-08-93$ & 0430 & $07-08-93$ & 1300 & .45 & .304 & .675 & 28.6 & 60 & 480 & 22.8 \\
\hline $07-08-93$ & 1935 & $07-09-93$ & 0900 & .47 & .343 & .730 & 8.6 & 115 & 840 & 15.1 \\
\hline $07-10-93$ & 0405 & $07-10-93$ & 1400 & .41 & .170 & .415 & 19.5 & 10 & 600 & 32.5 \\
\hline $07-11-93$ & 0125 & $07-11-93$ & 1300 & .33 & .290 & .695 & 24.4 & 20 & 660 & 21.3 \\
\hline $07-13-93$ & 0435 & $07-13-93$ & 1500 & .89 & .601 & .675 & 48.6 & 70 & 660 & 51.2 \\
\hline 07-13-93 & 2105 & $07-14-93$ & 0700 & .29 & .194 & .668 & 5.6 & 30 & 660 & 16.5 \\
\hline $07-16-93$ & 0945 & $07-16-93$ & 1700 & .05 & .008 & .169 & .3 & 30 & 480 & 60.7 \\
\hline
\end{tabular}


Table 2. Storm rainfall and runoff characteristics for five sites, Omaha, Nebraska, 1992-93--Continued

\begin{tabular}{|c|c|c|c|c|c|c|c|c|c|c|}
\hline \multicolumn{4}{|c|}{ Storm duration } & \multirow{3}{*}{$\begin{array}{c}\text { Rainfall, } \\
\text { total } \\
\text { (in.) }\end{array}$} & \multirow{3}{*}{$\begin{array}{c}\text { Runoff } \\
\text { volume, } \\
\text { total } \\
\text { (in.) }\end{array}$} & \multirow{3}{*}{$\begin{array}{c}\text { Runoff- } \\
\text { rainfall } \\
\text { ratio }\end{array}$} & \multirow{3}{*}{$\begin{array}{c}\text { Peak } \\
\text { dis- } \\
\text { charge } \\
\left(\mathrm{ft}^{3} / \mathrm{s}\right)\end{array}$} & \multirow{3}{*}{$\begin{array}{l}\text { Rainfall } \\
\text { dura- } \\
\text { tion } \\
\text { (min) }\end{array}$} & \multirow{3}{*}{$\begin{array}{c}\text { Runoff } \\
\text { dura- } \\
\text { tion } \\
\text { (min) }\end{array}$} & \multirow{3}{*}{$\begin{array}{c}\text { Time } \\
\text { since } \\
\text { previous } \\
\text { storm } \\
\text { (hrs) }\end{array}$} \\
\hline \multicolumn{2}{|c|}{ First rainfall } & \multicolumn{2}{|c|}{ End of runoff } & & & & & & & \\
\hline Date & Time & Date & Time & & & & & & & \\
\hline \multicolumn{11}{|c|}{ Commercial (site 2)-Continued } \\
\hline $07-17-93$ & 1525 & $07-18-93$ & 0300 & .20 & .089 & .443 & 1.1 & 160 & 660 & 29.7 \\
\hline $07-20-93$ & 0925 & $07-20-93$ & 1800 & .15 & .072 & .481 & 2.6 & 80 & 540 & 66.0 \\
\hline $07-21-93$ & 1125 & $07-22-93$ & 1900 & 1.93 & 1.58 & .807 & 56.4 & 345 & 1,920 & 26.0 \\
\hline $07-23-93$ & 0150 & $07-23-93$ & 1800 & .58 & .421 & .726 & 16.4 & 145 & 1,020 & 38.4 \\
\hline${ }^{3} 07-24-93$ & 0550 & $07-24-93$ & 1300 & .22 & .131 & .597 & 2.6 & 150 & 420 & 28.0 \\
\hline $07-24-93$ & 2015 & $07-25-93$ & 1300 & 1.14 & 1.122 & .984 & 86.7 & 50 & 1,020 & 14.4 \\
\hline $07-26-93$ & 1240 & $07-26-93$ & 1800 & .09 & .032 & .352 & 1.1 & 55 & 360 & 40.4 \\
\hline $07-27-93$ & 0840 & $07-27-93$ & 1700 & .08 & .025 & .313 & 1.0 & 45 & 540 & 20.0 \\
\hline $07-31-93$ & 1555 & $07-31-93$ & 1900 & .09 & .018 & .199 & 2.6 & 20 & 180 & 103.3 \\
\hline $08-05-93$ & 0635 & $08-05-93$ & 0900 & .03 & .004 & .134 & .3 & 20 & 180 & 110.7 \\
\hline $08-11-93$ & 1400 & $08-11-93$ & 2200 & 1.13 & .771 & .682 & 39.2 & 100 & 480 & 151.4 \\
\hline $08-12-93$ & 1925 & $08-13-93$ & 0200 & .31 & .206 & .663 & 30.5 & 20 & 420 & 29.4 \\
\hline $08-17-93$ & 0150 & $08-17-93$ & 1100 & .79 & .624 & .789 & 39.7 & 80 & 540 & 102.4 \\
\hline $08-19-93$ & 0130 & $08-19-93$ & 1600 & .22 & .133 & .603 & 3.1 & 130 & 900 & 48.0 \\
\hline $08-21-93$ & 1240 & $08-21-93$ & 2200 & .12 & .064 & .531 & 3.1 & 50 & 540 & 59.2 \\
\hline $08-23-93$ & 0215 & $08-23-93$ & 0800 & .08 & .032 & .403 & 1.2 & 65 & 360 & 37.6 \\
\hline \multicolumn{11}{|c|}{ Industrial (site 3) } \\
\hline $05-22-92$ & 1455 & $05-22-92$ & 2000 & .92 & .316 & .343 & 23.8 & 136 & 300 & 75.0 \\
\hline $05-25-92$ & 0431 & $05-25-92$ & 1200 & .20 & .033 & .165 & 1.2 & 322 & 420 & 61.6 \\
\hline $05-31-92$ & 2202 & $06-01-92$ & 0226 & .16 & .009 & .053 & .2 & 995 & 179 & 161.5 \\
\hline${ }^{2} 06-05-92$ & 2010 & $06-06-92$ & 0117 & .28 & .189 & .673 & 10.9 & 136 & 239 & 118.1 \\
\hline $06-14-92$ & 1138 & $06-14-92$ & 1322 & .08 & .025 & .316 & 3.7 & 102 & 97 & 207.5 \\
\hline $06-17-92$ & 0000 & $06-17-92$ & 0849 & .40 & .380 & .950 & 23.8 & 29 & 524 & 60.4 \\
\hline $06-24-92$ & 1019 & $06-24-92$ & 1334 & .12 & .045 & .372 & 4.9 & 72 & 171 & 178.3 \\
\hline $07-02-92$ & 0719 & $07-02-92$ & 1100 & .29 & .114 & .392 & 17.0 & 61 & 210 & 189.0 \\
\hline 07-04-92 & 2215 & $07-05-92$ & 0100 & .18 & .140 & .780 & 16.0 & 23 & 165 & 62.9 \\
\hline $07-05-92$ & 0621 & $07-05-92$ & 1400 & .41 & .254 & .620 & 11.8 & 294 & 440 & 8.1 \\
\hline $07-07-92$ & 0332 & $07-07-92$ & 0600 & .06 & .018 & .305 & 2.3 & 91 & 150 & 45.2 \\
\hline $07-09-92$ & 1301 & $07-09-92$ & 1900 & .29 & .084 & .291 & 4.8 & 159 & 330 & 57.5 \\
\hline${ }^{4} 07-18-92$ & 2304 & $07-19-92$ & 0615 & 1.49 & .721 & .484 & 60.1 & 39 & 413 & 145.5 \\
\hline $07-21-92$ & 2355 & $07-22-92$ & 0530 & .53 & .059 & .112 & 12.2 & 250 & 300 & 72.9 \\
\hline $07-24-92$ & 1345 & $07-24-92$ & 1520 & .07 & .003 & .044 & 1.2 & 55 & 70 & 61.8 \\
\hline
\end{tabular}


Table 2. Storm rainfall and runoff characteristics for five sites, Omaha, Nebraska, 1992-93--Continued

\begin{tabular}{|c|c|c|c|c|c|c|c|c|c|c|}
\hline \multicolumn{4}{|c|}{ Storm duration } & \multirow{3}{*}{$\begin{array}{c}\text { Rainfall, } \\
\text { total } \\
\text { (in.) }\end{array}$} & \multirow{3}{*}{$\begin{array}{c}\text { Runoff } \\
\text { volume, } \\
\text { total } \\
\text { (in.) }\end{array}$} & \multirow{3}{*}{$\begin{array}{c}\text { Runoff- } \\
\text { rainfall } \\
\text { ratio }\end{array}$} & \multirow{3}{*}{$\begin{array}{c}\text { Peak } \\
\text { dis- } \\
\text { charge } \\
\left(\mathrm{ft}^{3} / \mathrm{s}\right)\end{array}$} & \multirow{3}{*}{$\begin{array}{c}\text { Rainfall } \\
\text { dura- } \\
\text { tion } \\
\text { (min) }\end{array}$} & \multirow{3}{*}{$\begin{array}{l}\text { Runoff } \\
\text { dura- } \\
\text { tion } \\
\text { (min) }\end{array}$} & \multirow{3}{*}{$\begin{array}{c}\text { Time } \\
\text { since } \\
\text { previous } \\
\text { storm } \\
\text { (hrs) }\end{array}$} \\
\hline \multicolumn{2}{|c|}{ First rainfall } & \multicolumn{2}{|c|}{ End of runoff } & & & & & & & \\
\hline Date & Time & Date & Time & & & & & & & \\
\hline \multicolumn{11}{|c|}{ Industrial (site 3)-Continued } \\
\hline $07-24-92$ & 1945 & $07-24-92$ & 2155 & .18 & .022 & .121 & 7.8 & 5 & 125 & 6.0 \\
\hline $07-25-92$ & 1800 & $07-25-92$ & 2020 & .29 & .041 & .141 & 17.4 & 5 & 140 & 22.3 \\
\hline $07-28-92$ & 0545 & $07-28-92$ & 0830 & .29 & .037 & .128 & 12.1 & 175 & 155 & 59.7 \\
\hline $07-28-92$ & 1510 & $07-28-92$ & 1600 & .05 & .002 & .037 & 1.4 & 15 & 30 & 9.4 \\
\hline $07-30-92$ & 0040 & $07-30-92$ & 0610 & 1.16 & .204 & .176 & 44.4 & 270 & 310 & 33.5 \\
\hline $08-02-92$ & 0410 & $08-02-92$ & 0830 & 0.52 & 0.094 & 0.180 & 21.0 & 140 & 240 & 75.5 \\
\hline $08-07-92$ & 0320 & $08-07-92$ & 1600 & 1.76 & .345 & .196 & 103.7 & 90 & 740 & 119.2 \\
\hline $08-12-92$ & 0520 & $08-12-92$ & 0835 & .14 & .018 & .130 & 4.9 & 90 & 185 & 122.0 \\
\hline $08-25-92$ & 0855 & $08-25-92$ & 1440 & .20 & .038 & .192 & 4.1 & 350 & 315 & 315.6 \\
\hline $09-01-92$ & 1320 & $09-01-92$ & 2210 & .26 & .035 & .135 & 5.1 & 500 & 515 & 172.4 \\
\hline $09-02-92$ & 0120 & $09-02-92$ & 0735 & 1.24 & .214 & .172 & 38.8 & 185 & 370 & 12.0 \\
\hline $09-05-92$ & 0710 & $09-05-92$ & 1130 & .83 & .175 & .211 & 59.4 & 75 & 250 & 77.8 \\
\hline $09-05-92$ & 1630 & $09-05-92$ & 1825 & .05 & .013 & .255 & 2.7 & 1 & 105 & 9.3 \\
\hline $09-09-92$ & 0555 & $09-09-92$ & 0810 & .04 & .010 & .242 & 2.6 & 35 & 115 & 85.4 \\
\hline $09-14-92$ & 0525 & $09-14-92$ & 2255 & 1.42 & .423 & .298 & 35.7 & 430 & 1,045 & 119.5 \\
\hline $09-17-92$ & 2210 & $09-18-92$ & 0100 & .46 & .363 & .789 & 32.2 & 110 & -- & 88.7 \\
\hline $09-26-92$ & 0015 & $09-26-92$ & 0520 & .35 & .027 & .077 & 5.2 & 300 & 235 & 194.1 \\
\hline $10-07-92$ & 1705 & $10-08-92$ & 0935 & 2.08 & .815 & .392 & 14.5 & 1,119 & 950 & 280.8 \\
\hline $04-12-93$ & 0846 & $04-12-93$ & 1700 & .29 & .080 & .276 & 6.1 & 310 & 480 & -- \\
\hline $04-13-93$ & 0857 & $04-13-93$ & 1400 & .07 & .015 & .219 & 3.6 & 105 & 300 & 24.2 \\
\hline $04-15-93$ & 1447 & $04-16-93$ & 0100 & .19 & .079 & .415 & 3.8 & 420 & 600 & 53.8 \\
\hline $04-17-93$ & 0844 & $04-17-93$ & 1400 & .22 & .097 & .443 & 12.2 & 75 & 305 & 42.0 \\
\hline $04-18-93$ & 0235 & $04-19-93$ & 1100 & .24 & .096 & .398 & 9.1 & 273 & 495 & 17.9 \\
\hline $04-19-93$ & 1840 & $04-20-93$ & 0400 & .24 & .130 & .541 & 6.6 & 350 & 540 & 40.1 \\
\hline $05-11-93$ & 1524 & $05-11-93$ & 2100 & .07 & .027 & .380 & 1.5 & 81 & 315 & 524.7 \\
\hline $05-19-93$ & 1005 & $05-19-93$ & 1800 & .08 & .010 & .129 & 1.7 & 90 & 480 & 186.7 \\
\hline $05-22-93$ & 0525 & $05-22-93$ & 1200 & .49 & .222 & .454 & 20.2 & 175 & 360 & 254.0 \\
\hline $05-23-93$ & 0220 & $05-23-93$ & 0900 & .31 & .144 & .465 & 10.9 & 105 & 420 & 20.9 \\
\hline $05-30-93$ & 0546 & $05-30-93$ & 1100 & .18 & .037 & .203 & 9.8 & 99 & 300 & 167.5 \\
\hline $06-01-93$ & 1355 & $06-02-93$ & 0400 & .22 & .076 & .344 & 6.3 & 531 & 840 & 60.1 \\
\hline
\end{tabular}


Table 2. Storm rainfall and runoff characteristics for five sites, Omaha, Nebraska, 1992-93--Continued

\begin{tabular}{|c|c|c|c|c|c|c|c|c|c|c|}
\hline \multicolumn{4}{|c|}{ Storm duration } & \multirow{3}{*}{$\begin{array}{c}\text { Rainfall, } \\
\text { total } \\
\text { (in.) }\end{array}$} & \multirow{3}{*}{$\begin{array}{c}\text { Runoff } \\
\text { volume, } \\
\text { total } \\
\text { (In.) }\end{array}$} & \multirow{3}{*}{$\begin{array}{l}\text { Runoff- } \\
\text { rainfall } \\
\text { ratlo }\end{array}$} & \multirow{3}{*}{$\begin{array}{c}\text { Peak } \\
\text { dls- } \\
\text { charge } \\
\left(\mathrm{ft}^{3} / \mathrm{s}\right)\end{array}$} & \multirow{3}{*}{$\begin{array}{c}\text { Rainfall } \\
\text { dura- } \\
\text { tlon } \\
\text { (min) }\end{array}$} & \multirow{3}{*}{$\begin{array}{c}\text { Runoff } \\
\text { dura- } \\
\text { tion } \\
\text { (min) }\end{array}$} & \multirow{3}{*}{$\begin{array}{c}\text { Time } \\
\text { since } \\
\text { previous } \\
\text { storm } \\
\text { (hrs) }\end{array}$} \\
\hline \multicolumn{2}{|c|}{ First rainfall } & \multicolumn{2}{|c|}{ End of runoff } & & & & & & & \\
\hline Date & Time & Date & Time & & & & & & & \\
\hline \multicolumn{11}{|c|}{ Industrial (site 3)-Continued } \\
\hline $06-03-93$ & 1645 & $06-04-93$ & 1400 & .65 & .332 & .511 & 9.7 & 960 & 900 & 50.8 \\
\hline $06-06-93$ & 0335 & $06-06-93$ & 1400 & .42 & .176 & .418 & 14.1 & 420 & 660 & 58.8 \\
\hline $06-11-93$ & 1735 & $06-12-93$ & 0300 & .44 & .119 & .271 & 15.7 & 306 & 480 & 134.0 \\
\hline $06-13-93$ & 0340 & $06-13-93$ & 1200 & .57 & .213 & .374 & 15.1 & 405 & 540 & 34.1 \\
\hline $06-17-93$ & 1755 & $06-17-93$ & 2130 & .36 & .144 & .400 & 13.0 & 147 & 215 & 110.3 \\
\hline $06-18-93$ & 0240 & $06-18-93$ & 2100 & 1.19 & .582 & .489 & 65.9 & 810 & 1,020 & 8.8 \\
\hline $06-19-93$ & 0610 & $06-19-93$ & 1200 & .12 & .033 & .274 & 1.5 & 186 & 300 & 27.5 \\
\hline $06-23-93$ & 0325 & $06-23-93$ & 1100 & 0.09 & 0.008 & 0.093 & 0.6 & 300 & 240 & 93.3 \\
\hline $06-24-93$ & 0150 & $06-24-93$ & 1200 & .93 & .376 & .405 & 26.1 & 330 & 600 & 116.0 \\
\hline $06-28-93$ & 0100 & $06-28-93$ & 1300 & 1.70 & .661 & .389 & 55.3 & 510 & 720 & 95.2 \\
\hline $06-30-93$ & 1632 & $06-30-93$ & 2400 & .32 & .084 & .262 & 13.0 & 290 & 420 & 60.6 \\
\hline $07-04-93$ & 0130 & $07-04-93$ & 0600 & .09 & .010 & .111 & 1.3 & 150 & 300 & 83.9 \\
\hline $07-05-93$ & 0150 & $07-05-93$ & 1800 & .62 & .252 & .407 & 7.1 & 810 & 780 & 24.3 \\
\hline $07-07-93$ & 0530 & $07-07-93$ & 1300 & .36 & .142 & .394 & 5.9 & 221 & 420 & 51.7 \\
\hline $07-08-93$ & 0425 & $07-08-93$ & 1000 & .31 & .134 & .434 & 17.1 & 117 & 360 & 22.9 \\
\hline $07-08-93$ & 1930 & $07-09-93$ & 0900 & .45 & .188 & .418 & 13.0 & 480 & 600 & 15.1 \\
\hline $07-10-93$ & 0310 & $07-10-93$ & 0900 & .41 & .202 & .493 & 30.6 & 150 & 300 & 31.7 \\
\hline $07-11-93$ & 0125 & $07-11-93$ & 0900 & .65 & .267 & .411 & 45.2 & 15 & 480 & 22.3 \\
\hline $07-13-93$ & 0430 & $07-13-93$ & 1300 & .88 & .363 & .413 & 50.2 & 105 & 540 & 51.1 \\
\hline $07-13-93$ & 2105 & $07-14-93$ & 0100 & .05 & .012 & .242 & .1 & 40 & 240 & 22.1 \\
\hline $07-17-93$ & 1340 & $07-18-93$ & 0200 & .24 & .058 & .243 & 1.6 & 528 & 600 & 88.6 \\
\hline $07-20-93$ & 0915 & $07-20-93$ & 1600 & .27 & .045 & .168 & 2.0 & 192 & 420 & 67.6 \\
\hline $07-21-93$ & 1125 & $07-22-93$ & 2000 & 2.18 & 1.186 & .544 & 64.7 & 1,350 & 1,980 & 26.2 \\
\hline $07-23-93$ & 0135 & $07-23-93$ & 1700 & .87 & .439 & .504 & 27.5 & 546 & 960 & 38.2 \\
\hline $07-24-93$ & 0550 & $07-24-93$ & 1300 & .22 & .090 & .411 & 3.9 & 150 & 420 & 28.3 \\
\hline $07-24-93$ & 2000 & $07-25-93$ & 1900 & 1.29 & .798 & .618 & 109.7 & 156 & 1,440 & 14.2 \\
\hline $07-26-93$ & 1245 & $07-26-93$ & 1900 & .07 & .031 & .439 & 1.4 & 48 & 360 & 40.8 \\
\hline $07-27-93$ & 0840 & $07-27-93$ & 1400 & .04 & .014 & .362 & .6 & 70 & 300 & 19.9 \\
\hline $07-31-93$ & 1615 & $07-31-93$ & 2000 & .09 & .021 & .235 & 2.1 & 174 & 240 & 103.6 \\
\hline $08-05-93$ & 0630 & $08-05-93$ & 1200 & .07 & .012 & .171 & .8 & 204 & 360 & 110.3 \\
\hline
\end{tabular}


Table 2. Storm rainfall and runoff characteristics for five sites, Omaha, Nebraska, 1992-93--Continued

\begin{tabular}{|c|c|c|c|c|c|c|c|c|c|c|}
\hline \multicolumn{4}{|c|}{ Storm duration } & \multirow{3}{*}{$\begin{array}{c}\text { Rainfall, } \\
\text { total } \\
\text { (In.) }\end{array}$} & \multirow{3}{*}{$\begin{array}{c}\text { Runoff } \\
\text { volume, } \\
\text { total } \\
\text { (In.) }\end{array}$} & \multirow{3}{*}{$\begin{array}{l}\text { Runoff- } \\
\text { rainfall } \\
\text { ratlo }\end{array}$} & \multirow{3}{*}{$\begin{array}{c}\text { Peak } \\
\text { dls- } \\
\text { charge } \\
\left(\mathrm{ft}^{3} / \mathrm{s}\right)\end{array}$} & \multirow{3}{*}{$\begin{array}{c}\text { Rainfall } \\
\text { dura- } \\
\text { tlon } \\
\text { (min) }\end{array}$} & \multirow{3}{*}{$\begin{array}{c}\text { Runoff } \\
\text { dura- } \\
\text { tion } \\
\text { (min) }\end{array}$} & \multirow{3}{*}{$\begin{array}{c}\text { Time } \\
\text { since } \\
\text { previous } \\
\text { storm } \\
\text { (hrs) }\end{array}$} \\
\hline \multicolumn{2}{|c|}{ First rainfall } & \multicolumn{2}{|c|}{ End of runoff } & & & & & & & \\
\hline Date & Time & Date & Time & & & & & & & \\
\hline \multicolumn{11}{|c|}{ Industrial (site 3)-Continued } \\
\hline $08-11-93$ & 1555 & $08-11-93$ & 2000 & .22 & .063 & .287 & 7.4 & 96 & 300 & 153.4 \\
\hline $08-12-93$ & 1910 & $08-13-93$ & 0100 & .39 & .150 & .384 & 30.4 & 35 & 360 & 27.3 \\
\hline $08-13-93$ & 0420 & $08-13-93$ & 0800 & .03 & .006 & .201 & .1 & 15 & 60 & 9.2 \\
\hline $08-15-93$ & 0720 & $08-15-93$ & 1100 & .02 & .008 & .418 & .5 & 5 & 240 & 51.0 \\
\hline $08-17-93$ & 0245 & $08-17-93$ & 0700 & .17 & .046 & .270 & 5.8 & 25 & 300 & 43.4 \\
\hline $08-19-93$ & 0125 & $08-19-93$ & 1000 & .29 & .083 & .287 & 4.6 & 190 & 480 & 46.7 \\
\hline $08-21-93$ & 1235 & $08-21-93$ & 1900 & .11 & .029 & .266 & 3.4 & 45 & 240 & 59.2 \\
\hline $08-23-93$ & 0220 & $08-23-93$ & 0700 & .08 & .017 & .211 & 1.2 & 50 & 300 & 37.8 \\
\hline \multicolumn{11}{|c|}{ Residential, multiple-dwelling (site 4) } \\
\hline $05-22-92$ & 1317 & $05-23-92$ & 0000 & 0.11 & 0.010 & 0.091 & 2.2 & 210 & 435 & -- \\
\hline $05-25-92$ & 0410 & $05-25-92$ & 1900 & .20 & .026 & .130 & 2.8 & 408 & 855 & 62.9 \\
\hline${ }^{3} 05-31-92$ & 2202 & $06-01-92$ & 0518 & .16 & .025 & .156 & 1.3 & 600 & 377 & 161.9 \\
\hline $06-01-92$ & 0858 & $06-01-92$ & 1157 & .04 & .021 & .515 & 1.4 & 76 & 280 & 10.9 \\
\hline $06-05-92$ & 2010 & $06-06-92$ & 0106 & .29 & .025 & .087 & 6.9 & 136 & 480 & 107.2 \\
\hline${ }^{4} 06-16-92$ & 2249 & $06-17-92$ & 1000 & .59 & .042 & .071 & 23.3 & 510 & 600 & 266.4 \\
\hline $06-24-92$ & 1005 & $06-24-92$ & 1600 & .14 & .007 & .052 & 2.2 & 105 & 315 & 179.2 \\
\hline $07-02-92$ & 0720 & $07-02-92$ & 1228 & .49 & .050 & .102 & 14.4 & 180 & 300 & 189.2 \\
\hline $07-04-92$ & 2145 & $07-05-92$ & 1630 & .91 & .130 & .143 & 34.4 & 802 & 1,110 & 62.4 \\
\hline $07-07-92$ & 0328 & $07-07-92$ & 0830 & .08 & .008 & .094 & 2.0 & 29 & 300 & 53.7 \\
\hline $07-11-92$ & 0925 & $07-11-92$ & 1635 & .77 & .116 & .151 & 25.2 & 350 & 405 & 102.0 \\
\hline $07-12-92$ & 0340 & $07-12-92$ & 1615 & 1.76 & .381 & .216 & 129.6 & 160 & 750 & 18.2 \\
\hline $07-12-92$ & 2155 & $07-13-92$ & 1310 & .93 & .219 & .235 & 29.9 & 620 & 900 & 18.3 \\
\hline $07-21-92$ & 2355 & $07-22-92$ & 1350 & .92 & .137 & .148 & 37.5 & 415 & 615 & 218.0 \\
\hline $07-24-92$ & 1340 & $07-24-92$ & 2020 & .48 & .081 & .168 & 32.6 & 55 & 390 & 61.8 \\
\hline $07-25-92$ & 1755 & $07-25-92$ & 2335 & .27 & .049 & .181 & 22.2 & 5 & 335 & 28.3 \\
\hline $07-28-92$ & 0530 & $07-28-92$ & 2040 & .58 & .101 & .174 & 30.2 & 55 & 860 & 59.6 \\
\hline $07-30-92$ & 0020 & $07-30-92$ & 1120 & .89 & .211 & .238 & 96.5 & 220 & 610 & 42.8 \\
\hline $08-02-92$ & 0405 & $08-02-92$ & 1645 & .69 & .158 & .228 & 45.0 & 140 & 740 & 75.8 \\
\hline $08-07-92$ & 0330 & $08-07-92$ & 1010 & 1.13 & .244 & .216 & 134.4 & 110 & 385 & 119.4 \\
\hline
\end{tabular}


Table 2. Storm rainfall and runoff characteristics for five sites, Omaha, Nebraska, 1992-93--Continued

\begin{tabular}{|c|c|c|c|c|c|c|c|c|c|c|}
\hline \multicolumn{4}{|c|}{ Storm duration } & \multirow{3}{*}{$\begin{array}{c}\text { Rainfall, } \\
\text { total } \\
\text { (in.) }\end{array}$} & \multirow{3}{*}{$\begin{array}{c}\text { Runoff } \\
\text { volume, } \\
\text { total } \\
\text { (in.) }\end{array}$} & \multirow{3}{*}{$\begin{array}{l}\text { Runoff- } \\
\text { rainfall } \\
\text { ratio }\end{array}$} & \multirow{3}{*}{$\begin{array}{l}\text { Peak } \\
\text { dis- } \\
\text { charge } \\
\left(\mathrm{ft}^{3} / \mathbf{s}\right)\end{array}$} & \multirow{3}{*}{$\begin{array}{c}\text { Rainfall } \\
\text { dura- } \\
\text { tion } \\
\text { (min) }\end{array}$} & \multirow{3}{*}{$\begin{array}{c}\text { Runoff } \\
\text { dura- } \\
\text { tion } \\
\text { (min) }\end{array}$} & \multirow{3}{*}{$\begin{array}{c}\text { Time } \\
\text { since } \\
\text { previous } \\
\text { storm } \\
\text { (hrs) }\end{array}$} \\
\hline \multicolumn{2}{|c|}{ First rainfall } & \multicolumn{2}{|c|}{ End of runoff } & & & & & & & \\
\hline Date & Time & Date & Time & & & & & & & \\
\hline \multicolumn{11}{|c|}{ Residential, multiple-dwelling (site 4)-Continued } \\
\hline 08-12-92 & 0525 & $08-12-92$ & 0720 & .08 & .010 & .128 & 1.4 & 140 & 60 & 121.9 \\
\hline 08-25-92 & 0745 & $08-25-92$ & 1500 & .63 & .060 & .095 & 10.5 & 330 & 415 & 314.3 \\
\hline 09-01-92 & 1325 & $09-02-92$ & 0830 & .81 & .107 & .131 & 9.5 & 162 & 895 & 173.7 \\
\hline 09-02-92 & 2130 & 09-03-92 & 0025 & .08 & .003 & .040 & 3.5 & 1 & 150 & 32.1 \\
\hline 09-05-92 & 0705 & 09-05-92 & 1840 & .41 & .061 & .148 & 17.2 & 42 & 680 & 57.6 \\
\hline 09-07-92 & 0100 & $09-07-92$ & 0725 & .17 & .017 & .102 & 2.8 & 18 & 170 & 41.9 \\
\hline 09-14-92 & 0525 & $09-14-92$ & 1540 & 1.23 & .065 & .053 & 46.3 & 142 & 590 & 172.4 \\
\hline 09-15-92 & 0840 & $09-15-92$ & 1110 & .06 & .002 & .030 & 2.0 & 10 & 110 & 27.3 \\
\hline 09-17-92 & 2215 & $09-18-92$ & 0250 & .24 & .007 & .027 & 5.0 & 31 & 245 & 61.6 \\
\hline 09-26-92 & 0010 & $09-26-92$ & 0725 & .25 & .009 & .034 & 4.0 & 63 & 370 & 193.9 \\
\hline $10-07-92$ & 0115 & $10-08-92$ & 2245 & 2.08 & 0.480 & 0.231 & 32.2 & 1,435 & 1,745 & 265.1 \\
\hline $10-31-92$ & 1717 & $11-01-92$ & 0030 & 1.48 & .235 & .159 & 10.0 & 1,806 & 1,890 & 592.0 \\
\hline $05-06-93$ & 1245 & $05-07-93$ & 0500 & 1.46 & .060 & .040 & 19.6 & 555 & 540 & -- \\
\hline 05-07-93 & 2235 & $05-09-93$ & 0300 & .51 & .043 & .085 & 4.0 & 1,465 & 1,620 & 33.8 \\
\hline 05-09-93 & 2010 & $05-10-93$ & 2300 & .87 & .138 & .159 & 10.5 & 990 & 1,560 & 45.6 \\
\hline $05-11-93$ & 0015 & $05-11-93$ & 1100 & .10 & .012 & .117 & 1.8 & 150 & 600 & 28.1 \\
\hline $05-11-93$ & 1520 & $05-12-93$ & 0100 & .40 & .017 & .042 & 3.5 & 135 & 540 & 15.1 \\
\hline $05-19-93$ & 0949 & $05-19-93$ & 1300 & .06 & .002 & .041 & .4 & 83 & 150 & 186.5 \\
\hline $05-22-93$ & 0550 & $05-22-93$ & 1200 & .48 & .038 & .080 & 10.7 & 135 & 360 & 68.0 \\
\hline $05-23-93$ & 0220 & $05-23-92$ & 0900 & .30 & .033 & .110 & 6.7 & 120 & 420 & 20.5 \\
\hline $05-30-93$ & 0140 & $05-30-92$ & 0900 & .21 & .005 & .023 & 2.1 & 285 & 300 & 167.3 \\
\hline $06-01-93$ & 2240 & $06-02-93$ & 0600 & .21 & .013 & .062 & 2.7 & 195 & 420 & 69.0 \\
\hline 06-03-93 & 2015 & $06-04-93$ & 1800 & .76 & .160 & .211 & 19.0 & 305 & 1,260 & 25.4 \\
\hline 06-06-93. & 0145 & $06-06-93$ & 1900 & .66 & .159 & .241 & 38.2 & 78 & 960 & 53.5 \\
\hline $06-11-93$ & 1915 & $06-12-93$ & 0600 & .96 & .182 & .190 & 58.9 & 225 & 660 & 137.5 \\
\hline $06-13-93$ & 0330 . & $06-13-93$ & 1700 & 1.04 & .243 & .233 & 37.3 & 420 & 840 & 32.3 \\
\hline $06-17-93$ & 1800 & $06-18-93$ & 0100 & .28 & .035 & .123 & 7.5 & 115 & 360 & 110.5 \\
\hline $06-18-93$ & 0355 & $06-19-93$ & 0100 & 1.71 & .445 & .260 & 155.8 & 735 & 1,320 & 9.9 \\
\hline $06-19-93$ & 0150 & $06-19-93$ & 1400 & .12 & .020 & .167 & 2.1 & 480 & 480 & 21.9 \\
\hline $06-23-93$ & 0145 & $06-23-93$ & 1800 & .19 & .016 & .082 & 1.4 & 320 & 840 & 95.9 \\
\hline
\end{tabular}


Table 2. Storm rainfall and runoff characteristics for five sites, Omaha, Nebraska, 1992-93--Continued

\begin{tabular}{|c|c|c|c|c|c|c|c|c|c|c|}
\hline \multicolumn{4}{|c|}{ Storm duration } & \multirow{3}{*}{$\begin{array}{c}\text { Rainfall, } \\
\text { total } \\
\text { (In.) }\end{array}$} & \multirow{3}{*}{$\begin{array}{c}\text { Runoff } \\
\text { volume, } \\
\text { total } \\
\text { (in.) }\end{array}$} & \multirow{3}{*}{$\begin{array}{c}\text { Runoff- } \\
\text { rainfall } \\
\text { ratio }\end{array}$} & \multirow{3}{*}{$\begin{array}{c}\text { Peak } \\
\text { dis- } \\
\text { charge } \\
\left(\mathrm{ft}^{3} / \mathrm{s}\right)\end{array}$} & \multirow{3}{*}{$\begin{array}{l}\text { Rainfall } \\
\text { dura- } \\
\text { tion } \\
\text { (min) }\end{array}$} & \multirow{3}{*}{$\begin{array}{c}\text { Runoff } \\
\text { dura- } \\
\text { tion } \\
\text { (min) }\end{array}$} & \multirow{3}{*}{$\begin{array}{c}\text { Time } \\
\text { since } \\
\text { previous } \\
\text { storm } \\
\text { (hrs) }\end{array}$} \\
\hline First rai & fall & End of $\mathrm{r}$ & noff & & & & & & & \\
\hline Date & Time & Date & Time & & & & & & & \\
\hline \multicolumn{11}{|c|}{ Residential, multiple-dwelling (site 4)-Continued } \\
\hline $06-24-93$ & 0155 & $06-24-93$ & 1700 & .88 & .185 & .210 & 27.0 & 360 & 900 & 24.2 \\
\hline $06-28-93$ & 0050 & $06-28-93$ & 2000 & .73 & .143 & .195 & 23.5 & 555 & 1,140 & 94.9 \\
\hline $06-30-93$ & 1755 & $07-01-93$ & 0100 & .35 & .072 & .205 & 22.9 & 130 & 480 & 65.1 \\
\hline $07-04-93$ & 0120 & 07-04-93 & 1000 & .09 & .019 & .212 & 3.9 & 175 & 480 & 79.4 \\
\hline $07-05-93$ & 0415 & $07-05-93$ & 2100 & .77 & .179 & .233 & 17.1 & 660 & 960 & 26.9 \\
\hline $07-07-93$ & 0525 & $07-07-93$ & 2300 & .35 & .096 & .274 & 11.1 & 210 & 1,020 & 49.2 \\
\hline $07-08-93$ & 0425 & $07-08-93$ & 1600 & .47 & .156 & .332 & 50.7 & 150 & 720 & 23.0 \\
\hline $07-08-93$ & 1930 & $07-09-93$ & 0900 & .41 & .122 & .298 & 21.4 & 465 & 780 & 15.1 \\
\hline${ }^{4} 07-10-93$ & 0405 & $07-10-93$ & 1400 & .17 & .065 & .379 & 12.9 & 10 & 600 & 32.6 \\
\hline${ }^{4} 07-11-93$ & 0125 & $07-11-93$ & 1700 & .33 & .176 & .534 & 71.2 & 20 & 960 & $21: 3$ \\
\hline $07-13-93$ & 0400 & $07-13-93$ & 1800 & 1.60 & 0.249 & 0.155 & 87.4 & 70 & 840 & 50.6 \\
\hline $07-13-93$ & 2055 & $07-14-93$ & 0600 & .43 & .190 & .442 & 44.2 & 45 & 540 & 16.9 \\
\hline $07-14-93$ & 0905 & $07-14-93$ & 1300 & .07 & .018 & .255 & 5.8 & 10 & 240 & 12.2 \\
\hline $07-16-93$ & 0925 & $07-16-93$ & 1900 & .09 & .031 & .344 & 4.5 & 255 & 540 & 48.3 \\
\hline $07-17-93$ & 1320 & $07-18-93$ & 0700 & .20 & .066 & .330 & 4.8 & 525 & 1,080 & 27.9 \\
\hline $07-20-93$ & 0855 & $07-20-93$ & 1700 & .29 & .052 & .178 & 6.6 & 285 & 480 & 67.6 \\
\hline $07-21-93$ & 0920 & $07-23-93$ & 2100 & 3.06 & 1.110 & .363 & 277.0 & 2,085 & 3,600 & 24.4 \\
\hline $07-24-93$ & 0525 & $07-25-93$ & 1800 & 1.82 & .655 & .360 & 245.8 & 975 & 2,280 & 68.1 \\
\hline $07-26-93$ & 1230 & $07-26-93$ & 1800 & .09 & .021 & .231 & 3.0 & 65 & 360 & 55.1 \\
\hline $07-27-93$ & 0830 & $07-27-93$ & 1300 & .04 & .012 & .295 & 1.6 & 40 & 300 & 20.0 \\
\hline \multicolumn{11}{|c|}{ Commercial (site 5) } \\
\hline $05-22-92$ & 1554 & $05-22-92$ & 2000 & .14 & .010 & .071 & .9 & 84 & 240 & -- \\
\hline $05-25-92$ & 0422 & $05-25-92$ & 1200 & .21 & .010 & .048 & .7 & 121 & 450 & 60.5 \\
\hline $06-05-92$ & 2009 & $06-05-92$ & 2250 & .35 & .015 & .043 & 2.0 & 143 & 165 & 279.8 \\
\hline $06-17-92$ & 0000 & $06-17-92$ & 0430 & .51 & .039 & .077 & 26.7 & 29 & 270 & 267.9 \\
\hline $06-24-92$ & 1015 & $06-24-92$ & 1300 & .15 & .005 & .033 & 1.0 & 84 & 180 & 178.3 \\
\hline $07-02-92$ & 0720 & $07-02-92$ & 1300 & .41 & .022 & .054 & 6.4 & 75 & 345 & 189.1 \\
\hline $07-04-92$ & 2149 & $07-05-92$ & 0300 & .33 & .026 & .078 & 8.9 & 29 & 300 & 62.5 \\
\hline $07-05-92$ & 0602 & $07-05-92$ & 1500 & .44 & .027 & .061 & 1.8 & 310 & 525 & 8.2 \\
\hline 07-07-92 & 0327 & $07-07-92$ & 0600 & .13 & .005 & .040 & 1.9 & 37 & 150 & 45.4 \\
\hline $07-11-92$ & 0935 & $07-11-92$ & 1500 & .75 & .064 & .086 & 9.8 & 106 & 330 & 102.1 \\
\hline
\end{tabular}


Table 2. Storm rainfall and runoff characteristics for five sites, Omaha, Nebraska, 1992-93--Continued

\begin{tabular}{|c|c|c|c|c|c|c|c|c|c|c|}
\hline \multicolumn{4}{|c|}{ Storm duration } & \multirow{3}{*}{$\begin{array}{c}\text { Rainfall, } \\
\text { total } \\
\text { (in.) }\end{array}$} & \multirow{3}{*}{$\begin{array}{c}\text { Runoff } \\
\text { volume, } \\
\text { total } \\
\text { (in.) }\end{array}$} & \multirow{3}{*}{$\begin{array}{c}\text { Runoff- } \\
\text { rainfall } \\
\text { ratio }\end{array}$} & \multirow{3}{*}{$\begin{array}{c}\text { Peak } \\
\text { dis- } \\
\text { charge } \\
\left(\mathrm{ft}^{3} / \mathrm{s}\right)\end{array}$} & \multirow{3}{*}{$\begin{array}{c}\text { Rainfall } \\
\text { dura- } \\
\text { tion } \\
\text { (min) }\end{array}$} & \multirow{3}{*}{$\begin{array}{c}\text { Runoff } \\
\text { dura- } \\
\text { tion } \\
\text { (min) }\end{array}$} & \multirow{3}{*}{$\begin{array}{c}\text { Time } \\
\text { since } \\
\text { previous } \\
\text { storm } \\
\text { (hrs) }\end{array}$} \\
\hline \multicolumn{2}{|c|}{ First rainfall } & \multicolumn{2}{|c|}{ End of runoff } & & & & & & & \\
\hline Date & Time & Date & Time & & & & & & & \\
\hline \multicolumn{11}{|c|}{ Commercial (site 5)-Continued } \\
\hline $07-12-92$ & 0325 & $07-12-92$ & 0800 & 1.89 & -- & -- & -- & 166 & 285 & .3 \\
\hline $07-12-92$ & 2155 & $07-13-92$ & 0730 & 1.09 & .101 & .092 & 13.5 & 480 & 570 & 18.5 \\
\hline $07-22-92$ & 0015 & $07-22-92$ & 0500 & .95 & .090 & .094 & 25.9 & 210 & 300 & 218.3 \\
\hline $07-24-92$ & 1340 & $07-24-92$ & 1600 & .68 & .074 & .109 & 29.2 & 55 & 130 & 61.4 \\
\hline $07-25-92$ & 1755 & $07-25-92$ & 2000 & .37 & .033 & .088 & 29.3 & 10 & 120 & 28.3 \\
\hline $07-28-92$ & 0535 & $07-28-92$ & 0800 & .64 & .063 & .099 & 35.6 & 60 & 150 & 59.7 \\
\hline $07-30-92$ & 0040 & $07-30-92$ & 0420 & .80 & .125 & .156 & 19.0 & 200 & 210 & 43.1 \\
\hline $08-02-92$ & 0405 & $08-02-92$ & 0800 & .71 & .072 & .102 & 40.7 & 140 & 225 & 75.4 \\
\hline $08-07-92$ & 0325 & $08-07-92$ & 0655 & 1.73 & -- & -- & -- & 105 & 200 & 119.5 \\
\hline $08-12-92$ & 0525 & $08-12-92$ & 0700 & .09 & .004 & .048 & .7 & 30 & 90 & 146.6 \\
\hline $08-25-92$ & 0745 & $08-25-92$ & 1200 & .67 & .037 & .056 & 7.6 & 255 & 245 & 289.7 \\
\hline $09-01-92$ & 1325 & $09-01-92$ & 1930 & .17 & .001 & .008 & 1.1 & 285 & 150 & 173.7 \\
\hline $09-02-92$ & 0000 & $09-02-92$ & 0530 & .54 & .046 & .085 & 4.9 & 265 & 300 & 10.6 \\
\hline $09-02-92$ & 2130 & $09-02-92$ & 2200 & 0.04 & 0.004 & 0.097 & 1.7 & 1 & 30 & 21.5 \\
\hline $09-05-92$ & 0720 & $09-05-92$ & 0930 & .11 & .019 & .174 & 4.1 & 65 & 125 & 57.8 \\
\hline $09-09-92$ & 0555 & $09-09-92$ & 0800 & .05 & .007 & .142 & .3 & 35 & 115 & 94.6 \\
\hline $09-14-92$ & 0525 & $09-14-92$ & 1300 & 1.57 & .272 & .173 & 38.1 & 150 & 450 & 119.5 \\
\hline $09-17-92$ & 2210 & $09-18-92$ & 0100 & .41 & .052 & .126 & 16.9 & 120 & 160 & 88.7 \\
\hline $09-26-92$ & 0010 & $09-26-92$ & 0500 & .32 & .039 & .121 & 3.4 & 195 & 270 & 194.0 \\
\hline $10-07-92$ & 0425 & $10-07-92$ & 0520 & .06 & .003 & .057 & 1.9 & 20 & 35 & 268.2 \\
\hline $10-07-92$ & 1635 & $10-08-92$ & 1600 & 2.32 & .529 & .228 & 11.8 & 1,470 & 1,370 & 12.2 \\
\hline $10-31-92$ & 1711 & $10-31-92$ & 1830 & .14 & .005 & .037 & 2.8 & 34 & 75 & 576.6 \\
\hline $11-01-92$ & 1250 & $11-02-92$ & 0600 & 1.42 & .325 & .229 & 8.2 & 969 & 1,020 & 19.7 \\
\hline${ }^{3} 04-12-93$ & 0846 & $04-12-93$ & 1400 & .29 & .070 & .241 & 4.1 & 310 & 300 & - \\
\hline${ }^{3} 04-13-93$ & 0857 & $04-13-93$ & 1400 & .07 & .009 & .132 & 1.1 & 105 & 195 & 24.2 \\
\hline${ }^{3} 04-15-93$ & 1447 & $04-15-93$ & 2330 & .19 & .028 & .147 & 8.6 & 420 & 465 & 53.8 \\
\hline $04-17-93$ & 0844 & $04-17-93$ & 1400 & .22 & .060 & .271 & 24.2 & 75 & 315 & 42.0 \\
\hline $05-06-93$ & 1300 & $05-07-93$ & 0200 & .18 & .131 & .727 & 26.7 & 15 & 540 & 460.3 \\
\hline${ }^{2} 05-07-93$ & 2235 & $05-09-93$ & 0100 & .51 & .120 & .235 & 3.3 & 1,465 & 1,380 & 33.6 \\
\hline${ }^{2} 05-09-93$ & 2010 & $05-10-93$ & 2200 & .87 & .299 & .344 & 7.4 & 990 & 1560 & 45.6 \\
\hline
\end{tabular}


Table 2. Storm rainfall and runoff characteristics for five sites, Omaha, Nebraska, 1992-93--Continued

\begin{tabular}{|c|c|c|c|c|c|c|c|c|c|c|}
\hline \multicolumn{4}{|c|}{ Storm duration } & \multirow{3}{*}{$\begin{array}{c}\text { Rainfall, } \\
\text { total } \\
\text { (In.) }\end{array}$} & \multirow{3}{*}{$\begin{array}{c}\text { Runoff } \\
\text { volume, } \\
\text { total } \\
\text { (In.) }\end{array}$} & \multirow{3}{*}{$\begin{array}{c}\text { Runoff- } \\
\text { rainfall } \\
\text { ratlo }\end{array}$} & \multirow{3}{*}{$\begin{array}{l}\text { Peak } \\
\text { dis- } \\
\text { charge } \\
\left(\mathrm{ft}^{3} / \mathrm{s}\right)\end{array}$} & \multirow{3}{*}{$\begin{array}{l}\text { Rainfall } \\
\text { dura- } \\
\text { tion } \\
\text { (min) }\end{array}$} & \multirow{3}{*}{$\begin{array}{c}\text { Runoff } \\
\text { dura- } \\
\text { tlon } \\
\text { (min) }\end{array}$} & \multirow{3}{*}{$\begin{array}{c}\text { Time } \\
\text { since } \\
\text { prevlous } \\
\text { storm } \\
\text { (hrs) }\end{array}$} \\
\hline \multicolumn{2}{|c|}{ First rainfall } & \multicolumn{2}{|c|}{ End of runoff } & & & & & & & \\
\hline Date & TIme & Date & Time & & & & & & & \\
\hline \multicolumn{11}{|c|}{ Commercial (site 5)-Continued } \\
\hline${ }^{2} 05-11-93$ & 0015 & $05-11-93$ & 0900 & .10 & .025 & .245 & 3.1 & 150 & 540 & 28.1 \\
\hline $05-11-93$ & 1450 & $05-11-93$ & 2300 & .12 & .040 & .333 & 1.8 & 143 & 480 & 14.6 \\
\hline $05-19-93$ & 0949 & $05-19-93$ & 1300 & .04 & .005 & .113 & 1.9 & 83 & 150 & 187.0 \\
\hline $05-22-93$ & 0140 & $05-22-93$ & 1100 & .18 & .049 & .270 & 7.1 & 115 & 300 & 250 \\
\hline $05-23-93$ & 0225 & $05-23-93$ & 0800 & .20 & .046 & .228 & 3.5 & 105 & 360 & 24.8 \\
\hline $05-30-93$ & 0540 & $05-30-93$ & 0800 & .03 & .005 & .168 & 2.0 & 20 & 180 & 171.3 \\
\hline $06-01-93$ & 2245 & $06-02-93$ & 0300 & .15 & .036 & .238 & 4.0 & 80 & 300 & 65.1 \\
\hline $06-03-93$ & 2055 & $06-04-93$ & 1300 & .50 & .132 & .265 & 5.4 & 270 & 840 & 46.2 \\
\hline $06-06-93$ & 0330 & $06-06-93$ & 1300 & .35 & .103 & .295 & 26.6 & 85 & 660 & 54.6 \\
\hline $06-11-93$ & 1930 & $06-12-93$ & 0300 & .42 & .159 & .379 & 30.4 & $135^{\circ}$ & 480 & 136.0 \\
\hline $06-13-93$ & 0355 & $06-13-93$ & 2000 & .43 & -- & -- & -- & 340 & 1,020 & -- \\
\hline${ }^{2} 06-17-93$ & 1800 & $06-17-93$ & 2100 & .28 & .029 & .099 & 3.1 & 115 & 540 & 110.1 \\
\hline${ }^{2} 06-19-93$ & 0150 & $06-19-93$ & 1100 & .12 & -- & -- & -- & 480 & 1,200 & 31.8 \\
\hline $06-23-93$ & 0320 & $06-23-93$ & 0800 & .01 & .005 & .473 & .8 & 5 & 180 & 97.5 \\
\hline${ }^{2} 06-24-93$ & 0155 & $06-24-93$ & 1100 & .88 & .161 & .183 & 25.9 & 360 & 540 & 120 \\
\hline${ }^{2} 06-28-93$ & 0050 & $06-28-93$ & 1200 & 73 & 0.108 & 0.148 & $9: 8$ & 555 & 660 & 94.9 \\
\hline${ }^{2} 06-30-93$ & 1755 & $07-01-93$ & 0100 & .35 & .050 & .144 & 23.3 & 130 & 480 & 65.1 \\
\hline${ }^{2} 07-04-93$ & 0120 & $07-04-93$ & 0500 & .09 & .007 & .080 & 2.5 & 175 & 180 & 79.4 \\
\hline${ }^{2} 07-05-93$ & 0415 & $07-05-93$ & 1700 & .77 & .145 & .188 & 5.0 & 660 & 720 & 26.9 \\
\hline${ }^{2} 07-07-93$ & 0525 & $07-07-93$ & 1300 & .35 & .072 & .207 & 3.8 & 210 & 480 & 49.2 \\
\hline${ }^{2} 07-08-93$ & 0425 & $07-09-93$ & 0500 & .41 & .090 & .220 & 94.7 & 610 & 1,200 & 23.0 \\
\hline${ }^{4} 07-10-93$ & 0405 & $07-10-93$ & 1400 & .17 & .019 & .109 & 5.9 & 10 & 300 & 47.7 \\
\hline${ }^{4} 07-11-93$ & 0125 & $07-11-93$ & 0600 & .33 & .134 & .405 & 43.3 & 20 & 300 & 21.3 \\
\hline $07-16-93$ & 0922 & $07-16-93$ & 1600 & .18 & .017 & .094 & 5.5 & 267 & 390 & 128.0 \\
\hline $07-17-93$ & 1316 & $07-17-93$ & 2400 & .25 & .026 & .106 & 1.3 & 441 & 630 & 27.9 \\
\hline $07-20-93$ & 0900 & $07-20-93$ & 1200 & .30 & .028 & .094 & 4.0 & 82 & 180 & 67.7 \\
\hline
\end{tabular}

\footnotetext{
${ }^{1}$ Rain data collected from site 5 .

${ }^{2}$ Rain data collected from site 3 .

${ }^{3}$ Rain data collected from site 4.

${ }^{4}$ Rain data collected from site 2 .
} 


\section{APPENDIX B-WATER-QUALITY DATA COLLECTED FROM FIVE SITES, OMAHA, NEBRASKA, 1992-93}


Table 3. Constituents and properties and detection limits in water samples collected at the five monitoring sites from six stormwater-runoff events, Omaha, Nebraska, 1992-93

[See figure 2 for site locations. $\mu \mathrm{g} / \mathrm{L}$, microgram per liter; --, not analyzed; $\mathrm{mg} / \mathrm{L}$, milligram per liter; $\mathrm{D}$, detected in one or more samples; $\mathrm{N}$, not detected; tons/acre-ft, tons per acre-foot; cols $/ 100 \mathrm{~mL}$, colonies per 100 milliliters; NA, not applicable; $\mu \mathrm{S} / \mathrm{cm}$, microsiemens per centimeter at 25 degrees Celsius]

\begin{tabular}{|c|c|c|c|c|c|c|c|}
\hline \multirow[b]{2}{*}{ Constituent or property } & \multirow{2}{*}{$\begin{array}{l}\text { Analytical } \\
\text { detection } \\
\text { limit }\end{array}$} & \multirow[b]{2}{*}{ Unit } & \multicolumn{5}{|c|}{ Site number (flg. 2) } \\
\hline & & & 1 & 2 & 3 & 4 & 5 \\
\hline \multicolumn{8}{|c|}{ Volatile organic compounds } \\
\hline Acrolein, total & 20 & $\mu \mathrm{g} / \mathrm{L}$ & $\mathrm{N}$ & $\mathrm{N}$ & $\mathrm{N}$ & $\mathrm{N}$ & $\mathrm{N}$ \\
\hline Acrylonitrile, total & 20 & $\mu \mathrm{g} / \mathrm{L}$ & $\mathrm{N}$ & $\mathrm{N}$ & $\mathrm{N}$ & $\mathbf{N}$ & $\mathrm{N}$ \\
\hline Benzene, total & .2 & $\mu \mathrm{g} / \mathrm{L}$ & $\mathrm{N}$ & $\mathrm{N}$ & $\mathbf{N}$ & $\mathrm{N}$ & $\mathrm{N}$ \\
\hline Bromoform, total & .2 & $\mu \mathrm{g} / \mathrm{L}$ & $\mathrm{N}$ & $\mathrm{N}$ & $\mathrm{N}$ & $\mathrm{N}$ & $\mathrm{N}$ \\
\hline Carbon tetrachloride, total & .2 & $\mu \mathrm{g} / \mathrm{L}$ & $\mathrm{N}$ & $\mathbf{N}$ & $\mathbf{N}$ & $\mathbf{N}$ & $\mathrm{N}$ \\
\hline Chlorobenzene & .2 & $\mu \mathrm{g} / \mathrm{L}$ & $\mathrm{N}$ & $\mathrm{N}$ & $\mathbf{N}$ & $\mathrm{N}$ & $\mathrm{N}$ \\
\hline Chlorodibromomethane & .2 & $\mu \mathrm{g} / \mathrm{L}$ & $\mathrm{N}$ & $\mathrm{N}$ & $\mathbf{N}$ & $\mathrm{N}$ & $\mathrm{N}$ \\
\hline Chloroethane & .2 & $\mu \mathrm{g} / \mathrm{L}$ & $\mathrm{N}$ & $\mathbf{N}$ & $\mathbf{N}$ & $\mathbf{N}$ & $\mathbf{N}$ \\
\hline 2-Chloroethylvinyl ether & 1 & $\mu \mathrm{g} / \mathrm{L}$ & $\mathrm{N}$ & $\mathbf{N}$ & $\mathbf{N}$ & $\mathrm{N}$ & $\mathrm{N}$ \\
\hline Chloroform & .2 & $\mu \mathrm{g} / \mathrm{L}$ & $\mathbf{N}$ & $\mathbf{N}$ & D & D & D \\
\hline Dichlorobromomethane & .2 & $\mu \mathrm{g} / \mathrm{L}$ & $\mathrm{N}$ & $\mathbf{N}$ & $\mathbf{N}$ & D & D \\
\hline 1,1-Dichloroethane & .2 & $\mu \mathrm{g} / \mathrm{L}$ & $\mathrm{N}$ & $\mathbf{N}$ & $\mathrm{N}$ & $\mathrm{N}$ & $\mathbf{N}$ \\
\hline 1,2-Dichloroethane & .2 & $\mu \mathrm{g} / \mathrm{L}$ & $\mathrm{N}$ & $\mathrm{N}$ & $\mathbf{N}$ & $\mathbf{N}$ & $\mathrm{N}$ \\
\hline 1,1-Dichloroethylene & .2 & $\mu \mathrm{g} / \mathrm{L}$ & $\mathrm{N}$ & $\mathrm{N}$ & $\mathrm{N}$ & $\mathrm{N}$ & $\mathbf{N}$ \\
\hline 1,2-Dichloropropane & .2 & $\mu \mathrm{g} / \mathrm{L}$ & $\mathrm{N}$ & $\mathbf{N}$ & $\mathbf{N}$ & $\mathbf{N}$ & $\mathrm{N}$ \\
\hline 1,3-Dichloropropylene & .2 & $\mu \mathrm{g} / \mathrm{L}$ & $\mathbf{N}$ & $\mathbf{N}$ & $\mathbf{N}$ & $\mathbf{N}$ & $\mathbf{N}$ \\
\hline Ethylbenzene & .2 & $\mu \mathrm{g} / \mathrm{L}$ & $\mathrm{N}$ & $\mathrm{N}$ & $\mathrm{N}$ & $\mathrm{N}$ & $\mathrm{N}$ \\
\hline Methyl bromide & .2 & $\mu \mathrm{g} / \mathrm{L}$ & $\mathrm{N}$ & $\mathbf{N}$ & $\mathbf{N}$ & $\mathbf{N}$ & $\mathbf{N}$ \\
\hline Methyl chloride & .2 & $\mu \mathrm{g} / \mathrm{L}$ & D & $\mathrm{N}$ & D & $\mathrm{D}$ & D \\
\hline Methylene chloride & .2 & $\mu \mathrm{g} / \mathrm{L}$ & $\mathrm{N}$ & $\mathrm{N}$ & $\mathbf{N}$ & $\mathrm{N}$ & $\mathrm{N}$ \\
\hline 1,1,2,2-Tetrachloroethane & .2 & $\mu \mathrm{g} / \mathrm{L}$ & $\mathbf{N}$ & $\mathrm{N}$ & $\mathrm{N}$ & $\mathbf{N}$ & $\mathrm{N}$ \\
\hline Tetrachloroethylene & .2 & $\mu \mathrm{g} / \mathrm{L}$ & $\mathrm{N}$ & $\mathrm{N}$ & $\mathbf{N}$ & $\mathrm{N}$ & $\mathbf{N}$ \\
\hline Toluene & .2 & $\mu \mathrm{g} / \mathrm{L}$ & D & $\mathrm{N}$ & $\mathbf{N}$ & $\mathrm{D}$ & $\mathbf{N}$ \\
\hline 1,2-Transdichloroethylene & .2 & $\mu \mathrm{g} / \mathrm{L}$ & $\mathbf{N}$ & $\mathbf{N}$ & $\mathbf{N}$ & $\mathrm{N}$ & $\mathbf{N}$ \\
\hline 1,1,1-Trichloroethane & .2 & $\mu \mathrm{g} / \mathrm{L}$ & $\mathbf{N}$ & $\mathrm{N}$ & $\mathbf{N}$ & $\mathrm{N}$ & $\mathbf{N}$ \\
\hline 1, 1, 2-Trichloroethane & .2 & $\mu \mathrm{g} / \mathrm{L}$ & $\mathbf{N}$ & $\mathrm{N}$ & $\mathrm{N}$ & $\mathrm{N}$ & $\mathbf{N}$ \\
\hline Trichloroethylene & .2 & $\mu \mathrm{g} / \mathrm{L}$ & $\mathbf{N}$ & $\mathrm{N}$ & $\mathrm{N}$ & $\mathbf{N}$ & $\mathrm{N}$ \\
\hline Vinyl chloride & .2 & $\mu \mathrm{g} / \mathrm{L}$ & $\mathrm{N}$ & $\mathrm{N}$ & $\mathrm{N}$ & $\mathrm{N}$ & $\mathbf{N}$ \\
\hline
\end{tabular}


Table 3. Constituents and properties and detection limits in water samples collected at the five monitoring sites from six stormwater-runoff events, Omaha, Nebraska, 1992-93--Continued

\begin{tabular}{|c|c|c|c|c|c|c|c|}
\hline \multirow[b]{2}{*}{ Constltuent or property } & \multirow{2}{*}{$\begin{array}{l}\text { Analytical } \\
\text { detection } \\
\text { limit }\end{array}$} & \multirow[b]{2}{*}{ Unit } & \multicolumn{5}{|c|}{ Site number (fig. 2) } \\
\hline & & & 1 & 2 & 3 & 4 & 5 \\
\hline \multicolumn{8}{|c|}{ Acid organic compounds } \\
\hline 2-Chlorophenol & 5 & $\mu \mathrm{g} / \mathrm{L}$ & $\mathrm{N}$ & $\mathbf{N}$ & $N$ & $\mathrm{~N}$ & $\mathrm{~N}$ \\
\hline 2,4-Dichlorophenol & 5 & $\mu \mathrm{g} / \mathrm{L}$ & $\mathrm{N}$ & $\mathbf{N}$ & $\mathrm{N}$ & $\mathrm{N}$ & $\mathbf{N}$ \\
\hline 2,4-Dimethylphenol & 5 & $\mu \mathrm{g} / \mathrm{L}$ & $\mathrm{N}$ & $\mathrm{N}$ & $\mathbf{N}$ & $\mathrm{N}$ & $\mathbf{N}$ \\
\hline 4,6-Dinitro-O-cresol & 30 & $\mu \mathrm{g} / \mathrm{L}$ & $\mathrm{N}$ & $\mathrm{N}$ & $\mathrm{N}$ & $\mathrm{N}$ & $\mathrm{N}$ \\
\hline 2-Nitrophenol & 5 & $\mu \mathrm{g} / \mathrm{L}$ & $\mathrm{N}$ & $\mathrm{N}$ & $\mathbf{N}$ & $\mathbf{N}$ & $\mathrm{N}$ \\
\hline 4-Nitrophenol & 30 & $\mu \mathrm{g} / \mathrm{L}$ & $\mathrm{N}$ & $\mathrm{N}$ & $\mathrm{N}$ & $\mathrm{N}$ & $\mathrm{N}$ \\
\hline P-Choloro-M-cresol & 30 & $\mu \mathrm{g} / \mathrm{L}$ & $\mathrm{N}$ & $\mathrm{N}$ & $\mathrm{N}$ & $\mathrm{N}$ & $\mathrm{N}$ \\
\hline Pentachlorophenol & 30 & $\mu \mathrm{g} / \mathrm{L}$ & $\mathbf{N}$ & $\mathrm{N}$ & $\mathrm{N}$ & $\mathrm{N}$ & $\mathbf{N}$ \\
\hline Phenol & 5 & $\mu \mathrm{g} / \mathrm{L}$ & $\mathrm{N}$ & $N$ & $\mathrm{~N}$ & $\mathrm{~N}$ & $\mathrm{~N}$ \\
\hline 2,4,6-Trichlorophenol & 20 & $\mu \mathrm{g} / \mathrm{L}$ & $\mathrm{N}$ & $\mathrm{N}$ & $\mathrm{N}$ & $\mathrm{N}$ & $\mathrm{N}$ \\
\hline \multicolumn{8}{|c|}{ Base/neutral organic compounds } \\
\hline Acenaphthalene & 5 & $\mu \mathrm{g} / \mathrm{L}$ & $\mathrm{N}$ & $\mathrm{N}$ & $\mathrm{N}$ & $\mathrm{N}$ & $\mathrm{N}$ \\
\hline Acenaphthene & 5 & $\mu \mathrm{g} / \mathrm{L}$ & $\mathrm{N}$ & $\mathbf{N}$ & $\mathrm{N}$ & $N$ & $\mathbf{N}$ \\
\hline Anthracene & 5 & $\mu \mathrm{g} / \mathrm{L}$ & $\mathrm{N}$ & $\mathbf{N}$ & $\mathbf{N}$ & $\mathrm{N}$ & D \\
\hline Benzidine & 40 & $\mu \mathrm{g} / \mathrm{L}$ & $\mathbf{N}$ & $\mathrm{N}$ & $\mathrm{N}$ & $N$ & $\mathbf{N}$ \\
\hline Benzo-A-anthracene & 10 & $\mu \mathrm{g} / \mathrm{L}$ & $N$ & $\mathrm{~N}$ & $\mathrm{~N}$ & $\mathrm{~N}$ & $\mathrm{D}$ \\
\hline Benzo-A-pyrene & 10 & $\mu \mathrm{g} / \mathrm{L}$ & $\mathrm{N}$ & $\mathrm{N}$ & $\mathrm{N}$ & $\mathrm{N}$ & $\mathrm{D}$ \\
\hline 3,4-Benzofluoranthene & 10 & $\mu \mathrm{g} / \mathrm{L}$ & $\mathrm{N}$ & $\mathrm{N}$ & $\mathbf{N}$ & $\mathrm{N}$ & D \\
\hline 2,4-Benzo(ghi)perylene & 10 & $\mu \mathrm{g} / \mathrm{L}$ & $\mathrm{N}$ & $\mathrm{N}$ & $\mathrm{N}$ & $\mathrm{N}$ & D \\
\hline Benzo(k)fluoranthene & 10 & $\mu \mathrm{g} / \mathrm{L}$ & $\mathrm{N}$ & $\mathrm{N}$ & $\mathbf{N}$ & $\mathbf{N}$ & D \\
\hline Bis (2-Chloroethoxy) methane & 5 & $\mu \mathrm{g} / \mathrm{L}$ & $\mathrm{N}$ & $\mathrm{N}$ & $\mathbf{N}$ & $\mathrm{N}$ & $\mathrm{N}$ \\
\hline Bis (2-Chloroethyl) ether & 5 & $\mu \mathrm{g} / \mathrm{L}$ & $\mathrm{N}$ & $\mathrm{N}$ & $\mathrm{N}$ & $\mathrm{N}$ & $\mathrm{N}$ \\
\hline Bis (2-Chloroisopropyl) ether & 5 & $\mu \mathrm{g} / \mathrm{L}$ & $\mathrm{N}$ & $\mathrm{N}$ & $\mathbf{N}$ & $\mathrm{N}$ & $\mathrm{N}$ \\
\hline Bis (2-ethylhexyl) phthalate & 5 & $\mu \mathrm{g} / \mathrm{L}$ & $\mathrm{D}$ & D & D & D & $\mathrm{N}$ \\
\hline 4-Bromophenyl phenyl ether & 5 & $\mu \mathrm{g} / \mathrm{L}$ & $\mathbf{N}$ & $\mathrm{N}$ & $\mathbf{N}$ & $\mathrm{N}$ & $\mathrm{N}$ \\
\hline Butylbenzyl phthalate & 5 & $\mu \mathrm{g} / \mathrm{L}$ & $\mathrm{N}$ & $\mathrm{N}$ & $\mathrm{N}$ & $\mathbf{N}$ & $\mathrm{N}$ \\
\hline 2-Chloronaphthalene & 5 & $\mu \mathrm{g} / \mathrm{L}$ & $\mathbf{N}$ & $\mathrm{N}$ & $\mathrm{N}$ & $\mathrm{N}$ & $\mathrm{N}$ \\
\hline 4-Chlorophenyl phenyl ether & 5 & $\mu \mathrm{g} / \mathrm{L}$ & $\mathrm{N}$ & $\mathrm{N}$ & $\mathrm{N}$ & $\mathrm{N}$ & $\mathrm{N}$ \\
\hline Chrysene & 10 & $\mu \mathrm{g} / \mathrm{L}$ & $\mathrm{N}$ & $\mathrm{N}$ & $\mathrm{N}$ & $\mathrm{N}$ & D \\
\hline Dibenzo $(A, H)$ anthracene & 10 & $\mu \mathrm{g} / \mathrm{L}$ & $\mathrm{N}$ & $\mathrm{N}$ & $\mathrm{N}$ & $\mathrm{N}$ & $\mathrm{N}$ \\
\hline 1,2-Dichlorobenzene & 5 & $\mu \mathrm{g} / \mathrm{L}$ & $\mathrm{N}$ & $\mathrm{N}$ & $\mathrm{N}$ & $\mathrm{N}$ & $\mathrm{N}$ \\
\hline 1,3-Dichlorobenzene & 5 & $\mu \mathrm{g} / \mathrm{L}$ & $\mathrm{N}$ & $\mathrm{N}$ & $\mathrm{N}$ & $\mathrm{N}$ & $\mathbf{N}$ \\
\hline 1,4-Dichlorobenzene & 5 & $\mu \mathrm{g} / \mathrm{L}$ & $\mathrm{N}$ & $N$ & $\mathbf{N}$ & $\mathbf{N}$ & $\mathrm{N}$ \\
\hline 3,3-Dichlorobenzidine & 20 & $\mu \mathrm{g} / \mathrm{L}$ & $\mathrm{N}$ & $\mathrm{N}$ & $\mathbf{N}$ & $\mathrm{N}$ & $\mathrm{N}$ \\
\hline Diethyl phthalate & 5 & $\mu \mathrm{g} / \mathrm{L}$ & $\mathrm{N}$ & $\mathrm{N}$ & $\mathrm{N}$ & $\mathrm{N}$ & $\mathrm{N}$ \\
\hline Dimethyl phthalate & 5 & $\mu \mathrm{g} / \mathrm{L}$ & $\mathrm{N}$ & $\mathrm{N}$ & $\mathbf{N}$ & $\mathrm{N}$ & $\mathrm{N}$ \\
\hline
\end{tabular}


Table 3. Constituents and properties and detection limits in water samples collected at the five monitoring sites from six stormwater-runoff events, Omaha, Nebraska, 1992-93--Continued

\begin{tabular}{|c|c|c|c|c|c|c|c|}
\hline \multirow[b]{2}{*}{ Constituent or property } & \multirow{2}{*}{$\begin{array}{l}\text { Analytical } \\
\text { detection } \\
\text { limit }\end{array}$} & \multirow[b]{2}{*}{ Unit } & \multicolumn{5}{|c|}{ Site number (fig. 2) } \\
\hline & & & 1 & 2 & 3 & 4 & 5 \\
\hline \multicolumn{8}{|c|}{ Base/neutral organic compounds--Continued } \\
\hline Di-N-butyl phthalate & 5 & $\mu \mathrm{g} / \mathrm{L}$ & $\mathrm{N}$ & $\mathrm{N}$ & $\mathrm{N}$ & $\mathrm{N}$ & $\mathrm{N}$ \\
\hline 2,4-Dinitrotoluene & 5 & $\mu \mathrm{g} / \mathrm{L}$ & $\mathrm{N}$ & $\mathbf{N}$ & $\mathrm{N}$ & $\mathrm{N}$ & $\mathbf{N}$ \\
\hline 2,6-Dinitrotoluene & 5 & $\mu \mathrm{g} / \mathrm{L}$ & $\mathrm{N}$ & $\mathbf{N}$ & $\mathbf{N}$ & $\mathrm{N}$ & $\mathbf{N}$ \\
\hline Di-N-octyl phthlate & 10 & $\mu \mathrm{g} / \mathrm{L}$ & $\mathrm{N}$ & $\mathrm{N}$ & $\mathbf{N}$ & $\mathrm{N}$ & $\mathrm{N}$ \\
\hline 1,2-Diphenylhydrazine (azobenzene) & 5 & $\mu \mathrm{g} / \mathrm{L}$ & $\mathrm{N}$ & $\mathrm{N}$ & $\mathbf{N}$ & $\mathrm{N}$ & $\mathrm{N}$ \\
\hline Fluoranthene & 5 & $\mu \mathrm{g} / \mathrm{L}$ & D & D & $\mathrm{D}$ & $\mathrm{N}$ & $\mathrm{D}$ \\
\hline Fluorene & 5 & $\mu \mathrm{g} / \mathrm{L}$ & $\mathrm{N}$ & $\mathrm{N}$ & $\mathrm{N}$ & $\mathrm{N}$ & $\mathrm{N}$ \\
\hline Hexachlorobenzene & 5 & $\mu \mathrm{g} / \mathrm{L}$ & $\mathrm{N}$ & $\mathrm{N}$ & $\mathrm{N}$ & $\mathrm{N}$ & $\mathrm{N}$ \\
\hline Hexachlorobutadiene & 5 & $\mu \mathrm{g} / \mathrm{L}$ & $\mathrm{N}$ & $\mathrm{N}$ & $\mathrm{N}$ & $\mathrm{N}$ & $\mathrm{N}$ \\
\hline Hexachlorocyclopentadiene & 5 & $\mu \mathrm{g} / \mathrm{L}$ & $\mathrm{N}$ & $\mathbf{N}$ & $\mathbf{N}$ & $\mathrm{N}$ & $\mathrm{N}$ \\
\hline Hexachloroethane & 5 & $\mu \mathrm{g} / \mathrm{L}$ & $\mathrm{N}$ & $\mathrm{N}$ & $\mathbf{N}$ & $\mathrm{N}$ & $\mathrm{N}$ \\
\hline Indeno $(1,2,3-C D)$ pyrene & 10 & $\mu \mathrm{g} / \mathrm{L}$ & $\mathrm{N}$ & $\mathrm{N}$ & $\mathbf{N}$ & $\mathbf{N}$ & $\mathrm{D}$ \\
\hline Isophorone & 5 & $\mu \mathrm{g} / \mathrm{L}$ & $\mathrm{N}$ & $\mathrm{N}$ & $\mathbf{N}$ & $\mathrm{N}$ & $\mathrm{N}$ \\
\hline Napthalene & 5 & $\mu \mathrm{g} / \mathrm{L}$ & $\mathbf{N}$ & $\mathrm{N}$ & $\mathbf{N}$ & $\mathbf{N}$ & $\mathrm{N}$ \\
\hline Nitrobenzene & 5 & $\mu \mathrm{g} / \mathrm{L}$ & $\mathrm{N}$ & $\mathrm{N}$ & $\mathbf{N}$ & $\mathbf{N}$ & $\mathrm{N}$ \\
\hline N-Nitrosodimethylamine & 5 & $\mu \mathrm{g} / \mathrm{L}$ & $\mathbf{N}$ & $\mathbf{N}$ & $\mathrm{N}$ & $\mathbf{N}$ & $\mathbf{N}$ \\
\hline N-Nitrosodi-N-propylamine & 5 & $\mu \mathrm{g} / \mathrm{L}$ & $\mathrm{N}$ & $\mathrm{N}$ & $\mathrm{N}$ & $\mathrm{N}$ & $\mathrm{N}$ \\
\hline N-Nitrosodiphenylamine & 5 & $\mu \mathrm{g} / \mathrm{L}$ & $\mathbf{N}$ & $\mathrm{N}$ & $\mathbf{N}$ & $\mathrm{N}$ & $\mathrm{N}$ \\
\hline Phenanthrene & 5 & $\mu \mathrm{g} / \mathrm{L}$ & $\mathrm{N}$ & $\mathbf{N}$ & $\mathrm{D}$ & $\mathrm{N}$ & D \\
\hline Pyrene & 5 & $\mu \mathrm{g} / \mathrm{L}$ & D & $\mathbf{N}$ & $\mathrm{D}$ & $\mathbf{N}$ & D \\
\hline \multicolumn{8}{|c|}{ Pesticides and polychlorinated biphenyls } \\
\hline Aldrin & 0.04 & $\mu \mathrm{g} / \mathrm{L}$ & $\mathbf{N}$ & $\mathbf{N}$ & $\mathbf{N}$ & $\mathrm{N}$ & $\mathrm{N}$ \\
\hline Alpha-BHC & .03 & $\mu \mathrm{g} / \mathrm{L}$ & $\mathrm{N}$ & $\mathbf{N}$ & $\mathrm{N}$ & $\mathbf{N}$ & $\mathbf{N}$ \\
\hline Beta-BHC & .03 & $\mu \mathrm{g} / \mathrm{L}$ & $\mathbf{N}$ & $\mathbf{N}$ & $\mathbf{N}$ & $\mathrm{N}$ & $\mathrm{N}$ \\
\hline Gamma-BHC & .03 & $\mu \mathrm{g} / \mathrm{L}$ & $\mathbf{N}$ & $\mathrm{N}$ & $\mathbf{N}$ & $\mathrm{N}$ & $\mathbf{N}$ \\
\hline Delta-BHC & .09 & $\mu \mathrm{g} / \mathrm{L}$ & $\mathrm{N}$ & $\mathrm{N}$ & $\mathbf{N}$ & $\mathrm{N}$ & $\mathrm{N}$ \\
\hline Chlordane & .1 & $\mu \mathrm{g} / \mathrm{L}$ & $\mathrm{N}$ & $\mathrm{D}$ & D & D & $\mathrm{N}$ \\
\hline 4,4'-DDT & .1 & $\mu \mathrm{g} / \mathrm{L}$ & $\mathrm{N}$ & $\mathrm{N}$ & D & $\mathrm{N}$ & $\mathrm{N}$ \\
\hline 4,4'-DDE & .04 & $\mu \mathrm{g} / \mathrm{L}$ & $\mathrm{N}$ & $\mathbf{N}$ & D & $\mathbf{N}$ & $\mathrm{N}$ \\
\hline 4,4'-DDD & .1 & $\mu \mathrm{g} / \mathrm{L}$ & $\mathrm{N}$ & $\mathbf{N}$ & $\mathbf{N}$ & $\mathrm{N}$ & $\mathrm{N}$ \\
\hline Dieldrin & .02 & $\mu \mathrm{g} / \mathrm{L}$ & $\mathrm{N}$ & $\mathrm{N}$ & $\mathrm{N}$ & $\mathrm{N}$ & $\mathrm{N}$ \\
\hline
\end{tabular}


Table 3. Constituents and properties and detection limits in water samples collected at the five monitoring sites from six stormwater-runoff events, Omaha, Nebraska, 1992-93--Continued

\begin{tabular}{|c|c|c|c|c|c|c|c|}
\hline \multirow[b]{2}{*}{ Constituent or property } & \multirow{2}{*}{$\begin{array}{l}\text { Analytical } \\
\text { detection } \\
\text { limit }\end{array}$} & \multirow[b]{2}{*}{ Unit } & \multicolumn{5}{|c|}{ Site number (fig. 2) } \\
\hline & & & 1 & 2 & 3 & 4 & 5 \\
\hline \multicolumn{8}{|c|}{ Pesticides and polychlorinated biphenyls--Continued } \\
\hline Alpha-endosulfan & .1 & $\mu \mathrm{g} / \mathrm{L}$ & $\mathrm{N}$ & $\mathrm{N}$ & $\mathrm{N}$ & $\mathrm{N}$ & $\mathrm{N}$ \\
\hline Beta-endosulfan & .04 & $\mu \mathrm{g} / \mathrm{L}$ & $\mathrm{N}$ & $\mathrm{N}$ & $\mathrm{N}$ & $\mathrm{N}$ & $\mathrm{N}$ \\
\hline Endosulfan sulfate & 6 & $\mu \mathrm{g} / \mathrm{L}$ & $\mathrm{N}$ & $\mathrm{N}$ & $\mathrm{N}$ & $\mathrm{N}$ & $\mathrm{N}$ \\
\hline Endrin & 0.06 & $\mu \mathrm{g} / \mathrm{L}$ & $\mathrm{N}$ & $\mathrm{N}$ & $\mathrm{N}$ & $\mathrm{N}$ & $\mathrm{N}$ \\
\hline Endrin aldehyde & .2 & $\mu \mathrm{g} / \mathrm{L}$ & $\mathrm{N}$ & $\mathrm{N}$ & $\mathbf{N}$ & $\mathrm{N}$ & $\mathrm{N}$ \\
\hline Heptachlor & .03 & $\mu \mathrm{g} / \mathrm{L}$ & $\mathrm{N}$ & $\mathrm{N}$ & $\mathrm{N}$ & $\mathrm{N}$ & $\mathrm{N}$ \\
\hline Heptachlor epoxide & .8 & $\mu \mathrm{g} / \mathrm{L}$ & $\mathrm{N}$ & $\mathrm{N}$ & $\mathrm{N}$ & $\mathrm{N}$ & $\mathrm{N}$ \\
\hline PCB-1242 & .1 & $\mu \mathrm{g} / \mathrm{L}$ & $\mathrm{N}$ & $\mathrm{N}$ & $\mathrm{N}$ & D & $\mathrm{N}$ \\
\hline PCB-1254 & .1 & $\mu \mathrm{g} / \mathrm{L}$ & $\mathrm{N}$ & $\mathrm{N}$ & D & D & $\mathrm{N}$ \\
\hline PCB-1221 & .1 & $\mu \mathrm{g} / \mathrm{L}$ & $\mathrm{N}$ & $\mathrm{N}$ & $\mathrm{N}$ & $\mathrm{N}$ & $\mathbf{N}$ \\
\hline PCB-1232 & .1 & $\mu \mathrm{g} / \mathrm{L}$ & $\mathrm{N}$ & $\mathrm{N}$ & $\mathrm{N}$ & $\mathrm{N}$ & $\mathrm{N}$ \\
\hline PCB-1248 & .1 & $\mu \mathrm{g} / \mathrm{L}$ & $\mathrm{N}$ & $\mathrm{N}$ & $\mathrm{N}$ & $\mathrm{N}$ & $\mathrm{N}$ \\
\hline PCB-1260 & .1 & $\mu \mathrm{g} / \mathrm{L}$ & $\mathrm{N}$ & $\mathrm{N}$ & $\mathrm{N}$ & $\mathrm{N}$ & $\mathrm{N}$ \\
\hline PCB-1016 & .1 & $\mu \mathrm{g} / \mathrm{L}$ & $\mathrm{N}$ & $\mathbf{N}$ & $\mathbf{N}$ & $\mathbf{N}$ & $\mathrm{N}$ \\
\hline Toxaphene & 2 & $\mu \mathrm{g} / \mathrm{L}$ & $\mathrm{N}$ & $\mathrm{N}$ & $\mathbf{N}$ & $\mathrm{N}$ & $\mathrm{N}$ \\
\hline Diazinon & .01 & $\mu \mathrm{g} / \mathrm{L}$ & $\mathrm{D}$ & -- & -- & D & -- \\
\hline Carbaryl & .01 & $\mu \mathrm{g} / \mathrm{L}$ & $\mathrm{N}$ & -- & -- & D & $\mathrm{N}$ \\
\hline 2,4-D & .01 & $\mu \mathrm{g} / \mathrm{L}$ & D & -- & -- & D & D \\
\hline
\end{tabular}

Trace elements, cyanide, and total phenols

\begin{tabular}{|c|c|c|c|c|c|c|}
\hline Antimony, total & 10 & $\mu \mathrm{g} / \mathrm{L}$ & $\mathrm{N}$ & $\mathrm{N}$ & $\mathrm{N}$ & $\mathrm{N}$ \\
\hline Arsenic, total & 1 & $\mu \mathrm{g} / \mathrm{L}$ & $\mathrm{D}$ & D & D & D \\
\hline Beryllium, total & 10 & $\mu \mathrm{g} / \mathrm{L}$ & D & $\mathrm{N}$ & $\mathrm{N}$ & $\mathrm{N}$ \\
\hline Cadmium, total & 1 & $\mu \mathrm{g} / \mathrm{L}$ & $\mathrm{N}$ & $\mathrm{N}$ & D & $\mathrm{N}$ \\
\hline Chromium, total & 1 & $\mu \mathrm{g} / \mathrm{L}$ & $\mathrm{D}$ & $\mathrm{D}$ & $D$ & D \\
\hline Copper, total & 1 & $\mu \mathrm{g} / \mathrm{L}$ & D & D & $\mathrm{D}$ & D \\
\hline Cyanide, total & 10 & $\mu \mathrm{g} / \mathrm{L}$ & $\mathrm{N}$ & $\mathrm{N}$ & $\mathrm{N}$ & $\mathrm{N}$ \\
\hline Lead, total & 1 & $\mu g / L$ & D & D & $\mathrm{D}$ & $\mathrm{D}$ \\
\hline Mercury, total & .1 & $\mu \mathrm{g} / \mathrm{L}$ & $\mathrm{N}$ & $\mathrm{N}$ & $\mathrm{D}$ & D \\
\hline Nickel, total & 1 & $\mu \mathrm{g} / \mathrm{L}$ & D & D & D & D \\
\hline Phenols, total & 1 & $\mu \mathrm{g} / \mathrm{L}$ & D & D & $\mathrm{D}$ & $\mathrm{D}$ \\
\hline Selenium, total & 2 & $\mu \mathrm{g} / \mathrm{L}$ & $\mathrm{N}$ & $\mathrm{N}$ & $\mathrm{N}$ & $\mathrm{N}$ \\
\hline Silver, total & 1 & $\mu \mathrm{g} / \mathrm{L}$ & $\mathrm{N}$ & $\mathrm{N}$ & $\mathrm{N}$ & $\mathrm{N}$ \\
\hline Thallium, total & 10 & $\mu \mathrm{g} / \mathrm{L}$ & $\mathrm{N}$ & $\mathrm{N}$ & $\mathrm{N}$ & $\mathrm{N}$ \\
\hline Zinc, total & 10 & $\mu \mathrm{g} / \mathrm{L}$ & D & D & $\mathrm{D}$ & $\mathrm{D}$ \\
\hline
\end{tabular}


Table 3. Constituents and properties and detection limits in water samples collected at the five monitoring sites from six stormwater-runoff events, Omaha, Nebraska, 1992-93--Continued

\begin{tabular}{|c|c|c|c|c|c|c|c|}
\hline \multirow[b]{2}{*}{ Constituent or property } & \multirow{2}{*}{$\begin{array}{l}\text { Analytical } \\
\text { detection } \\
\text { limit }\end{array}$} & \multirow[b]{2}{*}{ Unit } & \multicolumn{5}{|c|}{ Site number (fig. 2) } \\
\hline & & & 1 & 2 & 3 & 4 & 5 \\
\hline \multicolumn{8}{|c|}{ Other conventional constituents or properties } \\
\hline Biochemical oxygen demand & 18 & $\mathrm{mg} / \mathrm{L}$ & D & D & D & D & D \\
\hline Chemical oxygen demand & 10 & $\mathrm{mg} / \mathrm{L}$ & D & D & $\mathrm{D}$ & $\mathrm{D}$ & D \\
\hline Suspended solids, total & 1 & $\mathrm{mg} / \mathrm{L}$ & D & D & $\mathrm{D}$ & D & D \\
\hline Dissolved solids, total & $\mathrm{NA}$ & tons/acre-ft & D & D & D & $\mathrm{D}$ & D \\
\hline Fecal coliform & NA & $\mathrm{cols} / 100 \mathrm{~mL}$ & $\mathrm{D}$ & $\mathrm{D}$ & $\mathrm{D}$ & D & D \\
\hline Fecal streptococcus & NA & cols $/ 100 \mathrm{~mL}$ & D & D & D & $\mathrm{D}$ & D \\
\hline Nitrogen, total, as nitrogen & 0.1 & $\mathrm{mg} / \mathrm{L}$ as $\mathrm{N}$ & D & D & $\mathrm{D}$ & $\mathrm{D}$ & D \\
\hline Nitrogen, ammonia plus organic, total & .2 & $\mathrm{mg} / \mathrm{L}$ as $\mathrm{N}$ & D & D & $\mathrm{D}$ & $\mathrm{D}$ & D \\
\hline Phosphorous, total, as phosphorous & .01 & $\mathrm{mg} / \mathrm{L}$ as $\mathrm{P}$ & D & D & D & D & D \\
\hline Phosphorous, dissolved, as phosphorous & .01 & $\mathrm{mg} / \mathrm{L}$ as $\mathrm{P}$ & D & D & D & D & D \\
\hline Oil and grease & 1 & $\mathrm{mg} / \mathrm{L}$ & D & D & $\mathrm{D}$ & $\mathrm{D}$ & D \\
\hline \multicolumn{8}{|c|}{ Major ions, properties, and total organic carbon } \\
\hline Alkalinity, total & 1 & $\mathrm{mg} / \mathrm{L}$ as $\mathrm{CaCO}_{3}$ & D & D & D & D & D \\
\hline Calcium, dissolved & .1 & $\mathrm{mg} / \mathrm{L}$ as $\mathrm{Ca}$ & D & D & $\mathrm{D}$ & $\mathrm{D}$ & D \\
\hline Chloride, dissolved & .01 & $\mathrm{mg} / \mathrm{L}$ as $\mathrm{Cl}$ & D & D & D & D & D \\
\hline Magnesium, dissolved & .1 & $\mathrm{mg} / \mathrm{L}$ as $\mathrm{Mg}$ & D & D & D & D & D \\
\hline Potassium, dissolved & .1 & $\mathrm{mg} / \mathrm{L}$ as $\mathrm{K}$ & D & D & D & $\mathrm{D}$ & D \\
\hline Sodium, dissolved & .1 & $\mathrm{mg} / \mathrm{L}$ as $\mathrm{Na}$ & D & D & D & D & D \\
\hline Sulfate, dissolved & .01 & $\mathrm{mg} / \mathrm{L}$ as $\mathrm{SO}_{4}$ & D & $\mathrm{D}$ & $\mathrm{D}$ & $\mathrm{D}$ & D \\
\hline $\mathrm{pH}$ & .1 & Standard units & NA & NA & NA & NA & NA \\
\hline Specific conductance & 1 & $\mu \mathrm{S} / \mathrm{cm}$ & D & $\mathrm{D}$ & $\mathrm{D}$ & $\mathrm{D}$ & D \\
\hline Total organic carbon & .1 & $\mathrm{mg} / \mathrm{L}$ as $\mathrm{C}$ & D & D & $\mathrm{D}$ & D & D \\
\hline
\end{tabular}


Table 4. Concentrations of volatile organic compounds in stormwater-runoff in grab samples from five sites, Omaha, Nebraska, 1992-93

[See figure 2 for site location. All units are in micrograms per liter; --, no data; N, not detected; MCL, Maximum Contaminant Level. Analytical detection limits for constituents are in appendix B, table 3]

\begin{tabular}{|c|c|c|c|c|c|}
\hline & & Chloroform & $\begin{array}{c}\text { Dichloro- } \\
\text { bromomethane }\end{array}$ & $\begin{array}{l}\text { Methyl } \\
\text { chloride }\end{array}$ & Toluene \\
\hline Site & Date sampled & $M C L^{\top}: 100$ & 100 & - & 1,000 \\
\hline \multirow[t]{6}{*}{1} & $06-05-92$ & $\mathrm{~N}$ & $\mathrm{~N}$ & $\mathrm{~N}$ & $\mathrm{~N}$ \\
\hline & $07-02-92$ & $\mathrm{~N}$ & $\mathrm{~N}$ & $\mathrm{~N}$ & $\mathrm{~N}$ \\
\hline & $08-25-92$ & $\mathrm{~N}$ & $\mathbf{N}$ & $\mathrm{N}$ & $\mathbf{N}$ \\
\hline & $10-07-92$ & $\mathrm{~N}$ & $\mathrm{~N}$ & 0.4 & 0.2 \\
\hline & $05-22-93$ & $\mathrm{~N}$ & $\mathrm{~N}$ & $\mathrm{~N}$ & $\mathrm{~N}$ \\
\hline & $06-17-93$ & $\mathrm{~N}$ & $\mathrm{~N}$ & $\mathrm{~N}$ & $N$ \\
\hline \multirow[t]{6}{*}{2} & $06-05-92$ & $\mathrm{~N}$ & $\mathrm{~N}$ & $\mathrm{~N}$ & $\mathrm{~N}$ \\
\hline & $07-02-92$ & $\mathrm{~N}$ & $\mathrm{~N}$ & $\mathrm{~N}$ & $\mathbf{N}$ \\
\hline & $08-25-92$ & $\mathrm{~N}$ & $\mathbf{N}$ & $\mathrm{N}$ & $\mathrm{N}$ \\
\hline & $06-17-93$ & $\mathrm{~N}$ & $\mathrm{~N}$ & $\mathrm{~N}$ & $\mathrm{~N}$ \\
\hline & $06-24-93$ & $N$ & $\mathrm{~N}$ & $N$ & $\mathbf{N}$ \\
\hline & $08-19-93$ & $\mathbf{N}$ & $\mathrm{N}$ & $\mathrm{N}$ & $\mathrm{N}$ \\
\hline \multirow[t]{6}{*}{3} & $05-22-92$ & $\mathrm{~N}$ & $\mathrm{~N}$ & $\mathrm{~N}$ & $\mathrm{~N}$ \\
\hline & $07-02-92$ & $\mathrm{~N}$ & $\mathrm{~N}$ & $\mathrm{~N}$ & $\mathbf{N}$ \\
\hline & $10-07-92$ & 1.0 & $\mathrm{~N}$ & .5 & $\mathbf{N}$ \\
\hline & $05-22-93$ & $\mathrm{~N}$ & $\mathrm{~N}$ & $\mathbf{N}$ & $\mathrm{N}$ \\
\hline & $06-17-93$ & $\mathrm{~N}$ & $\mathrm{~N}$ & $\mathrm{~N}$ & $\mathrm{~N}$ \\
\hline & $06-24-93$ & $\mathrm{~N}$ & $\mathrm{~N}$ & $\mathrm{~N}$ & $\mathrm{~N}$ \\
\hline \multirow[t]{6}{*}{4} & $06-17-92$ & $\mathrm{~N}$ & $\mathrm{~N}$ & $\mathbf{N}$ & .9 \\
\hline & $07-02-92$ & 1.0 & 0.2 & $\mathrm{~N}$ & 2.9 \\
\hline & $08-25-92$ & .2 & $\mathrm{~N}$ & $\mathrm{~N}$ & .4 \\
\hline & $10-07-92$ & .2 & $\mathrm{~N}$ & .3 & $\mathrm{~N}$ \\
\hline & $05-22-93$ & $\mathrm{~N}$ & $\mathrm{~N}$ & $\mathrm{~N}$ & .2 \\
\hline & $06-17-93$ & 7.0 & .4 & $\mathrm{~N}$ & $\mathrm{~N}$ \\
\hline \multirow[t]{6}{*}{5} & $06-05-92$ & $\mathrm{~N}$ & $\mathrm{~N}$ & $\mathrm{~N}$ & $\mathrm{~N}$ \\
\hline & $06-17-92$ & .4 & .2 & .2 & $\mathrm{~N}$ \\
\hline & $07-02-92$ & $\mathrm{~N}$ & $\mathrm{~N}$ & $N$ & $\mathrm{~N}$ \\
\hline & $05-22-93$ & $\mathbf{N}$ & $\mathrm{N}$ & $N$ & $\mathrm{~N}$ \\
\hline & $06-17-93$ & $\mathrm{~N}$ & $\mathrm{~N}$ & $\mathbf{N}$ & $\mathrm{N}$ \\
\hline & $06-24-93$ & $\mathrm{~N}$ & $\mathrm{~N}$ & $\mathrm{~N}$ & $\mathrm{~N}$ \\
\hline
\end{tabular}

\footnotetext{
${ }^{1}$ Maximum Contaminant Level. The highest concentration of a solute permissible in a public-water supply, as specified in the national Primary Drinking-Water Standards established under the Safe Drinking Water Act by the U.S. Environmental Protection Agency (1996).
} 


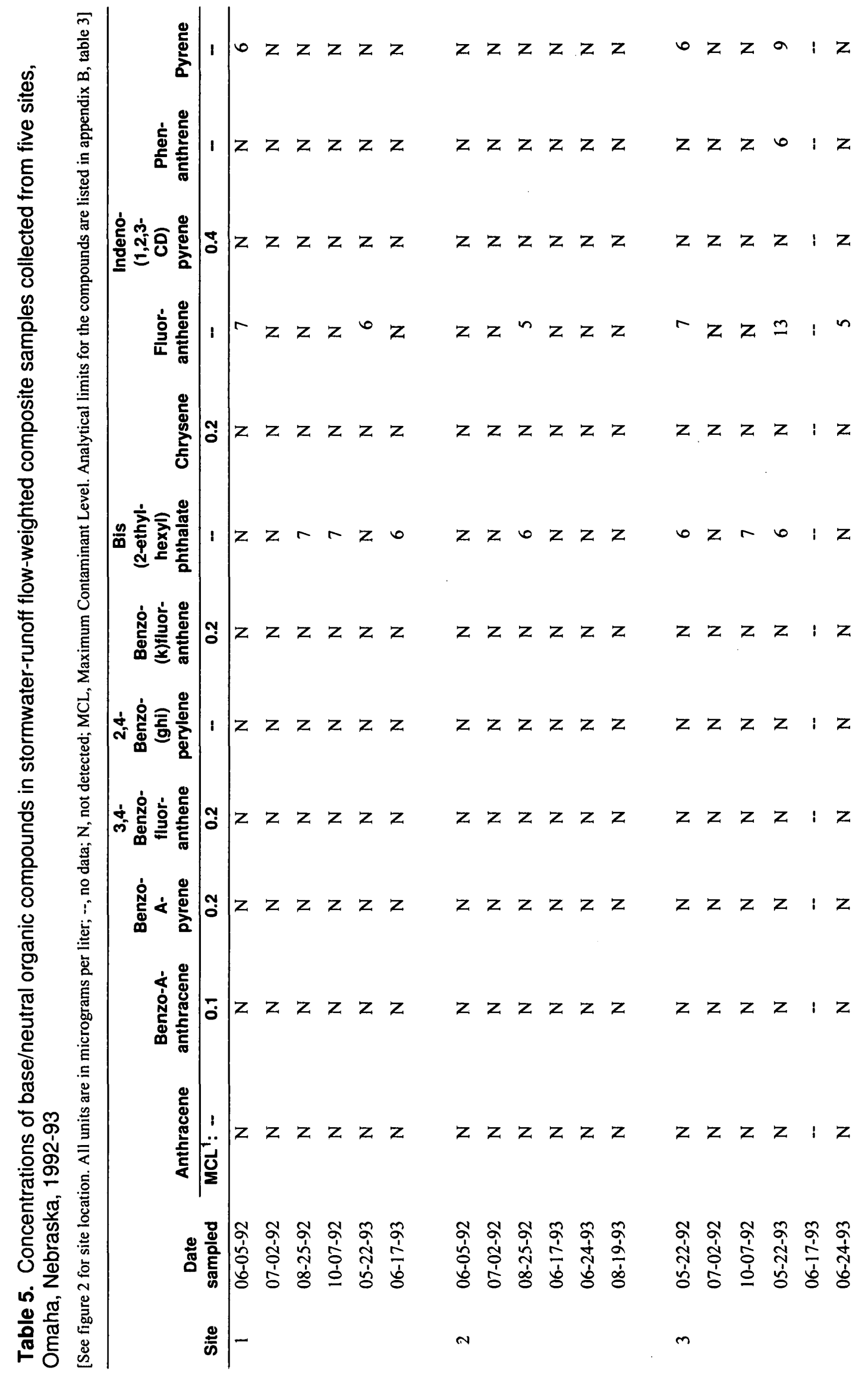

B-8 Quantity and Quality of Urban Stormwater Runoff from Selected Drainage Basins,

Omaha, Nebraska, 1992-93 


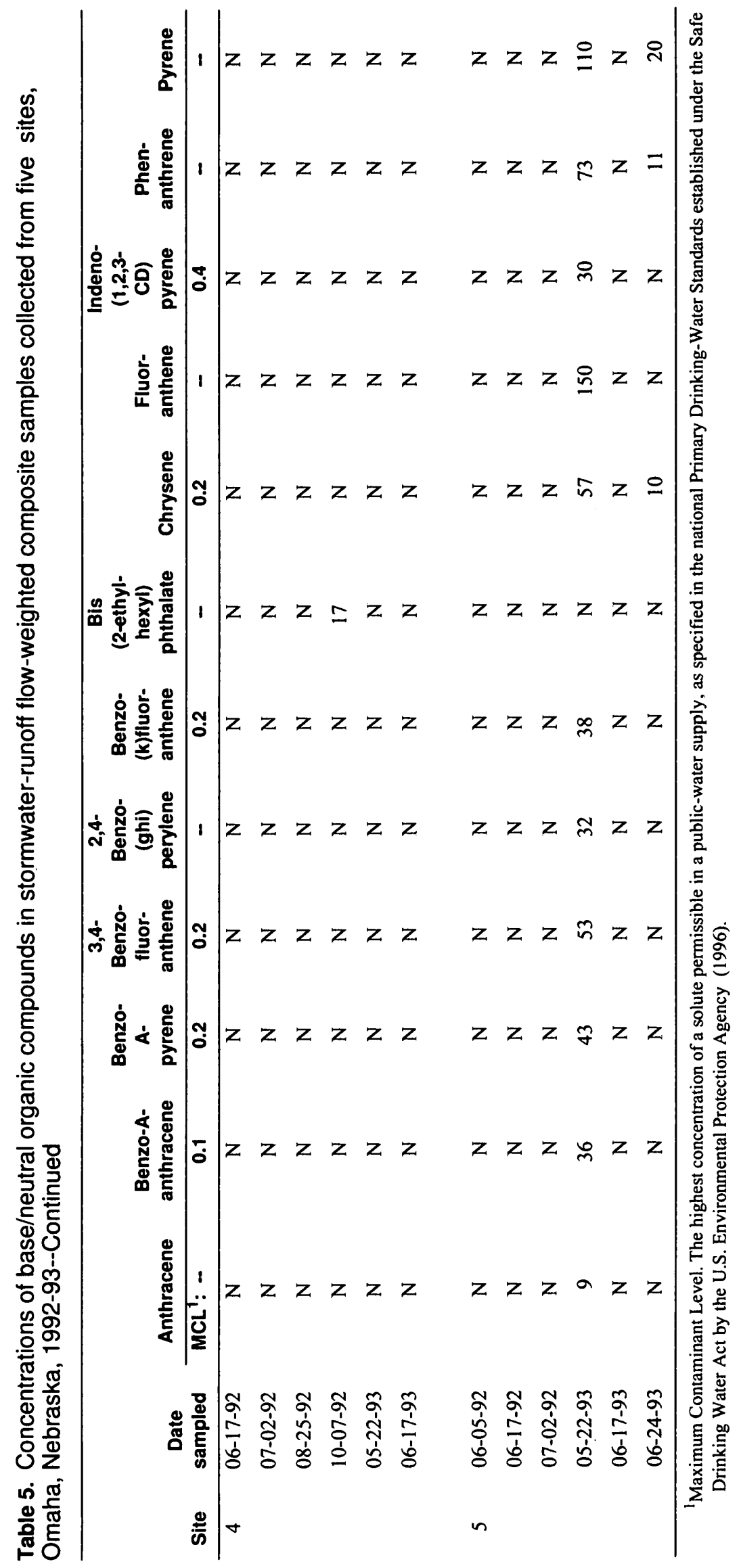




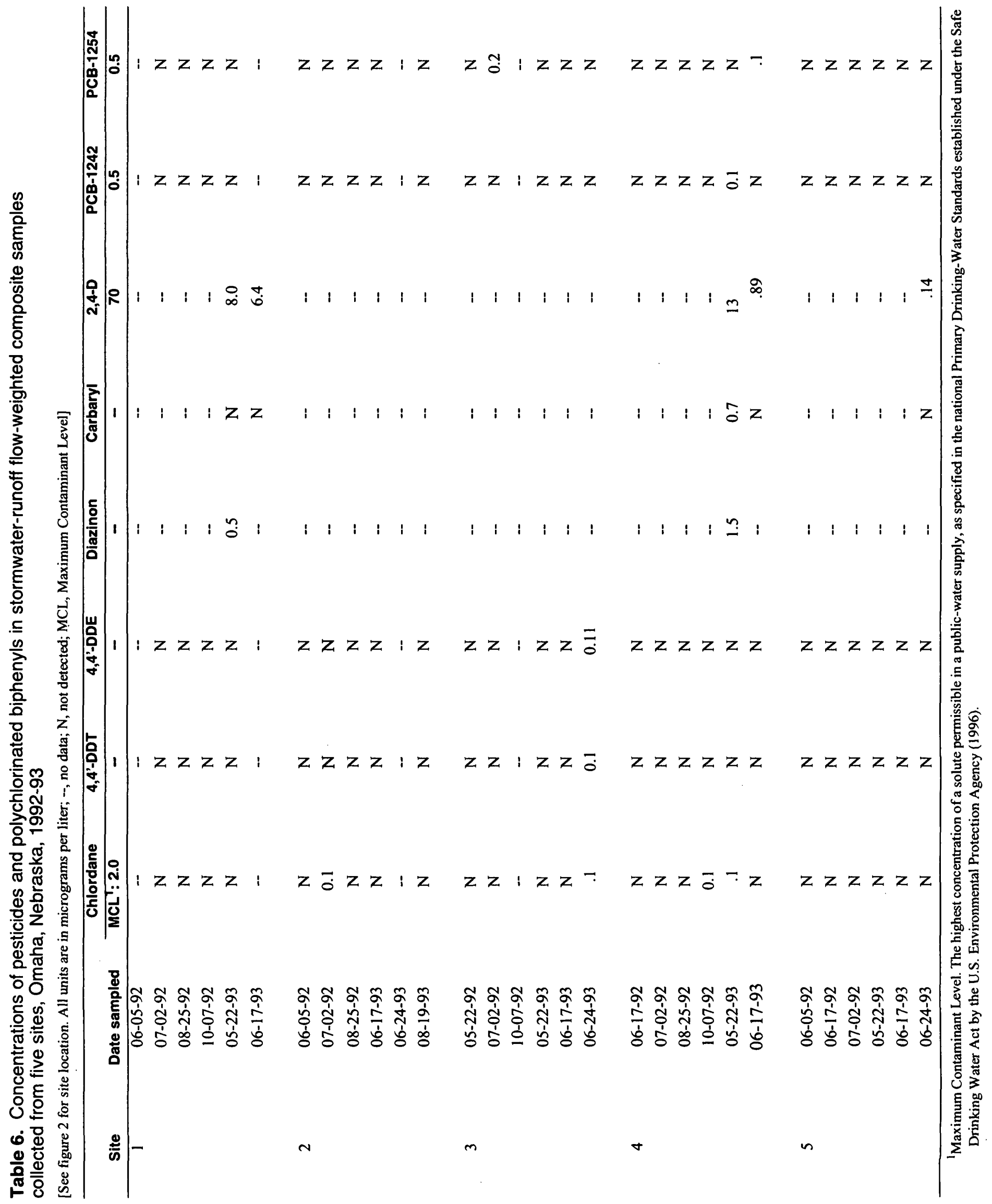




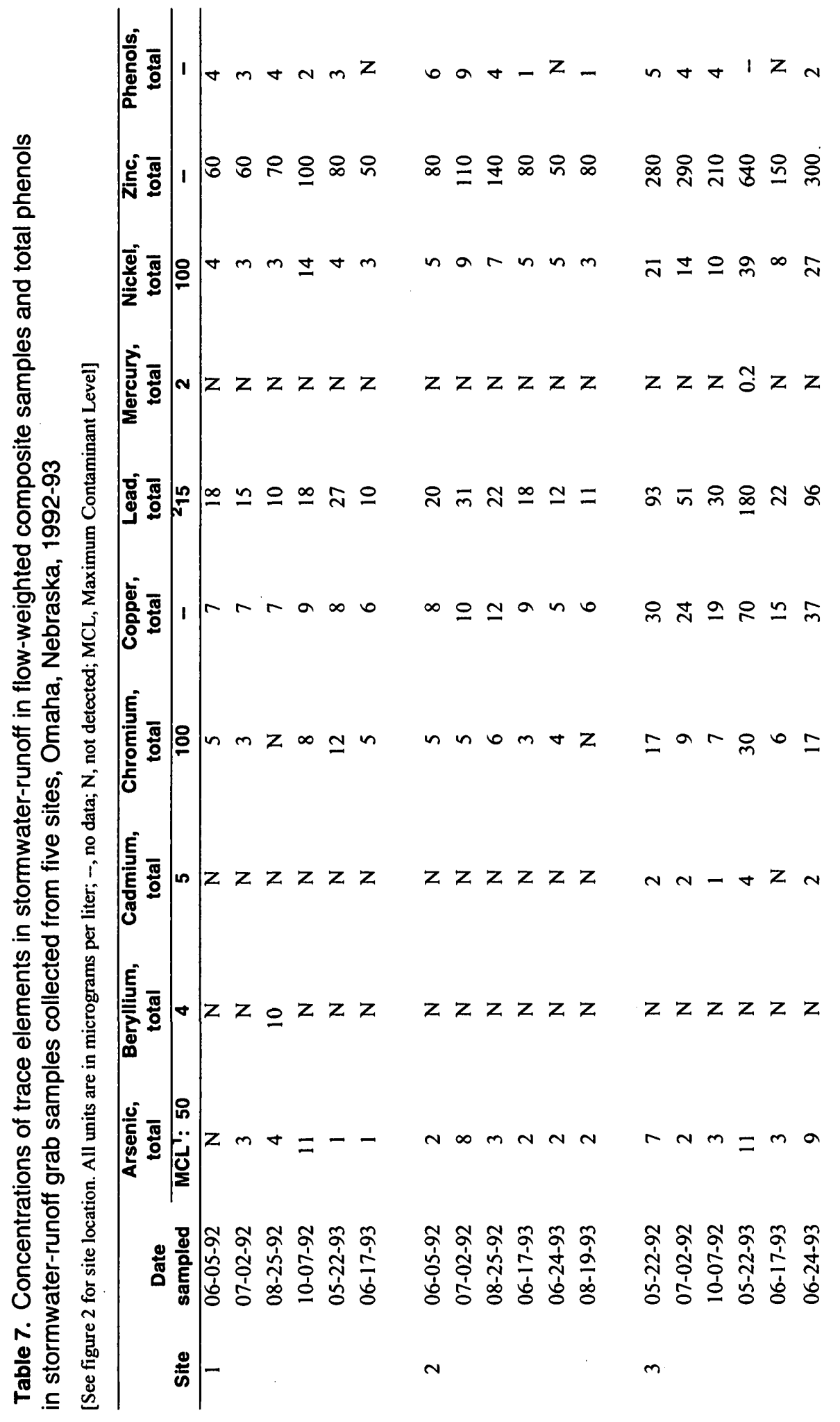




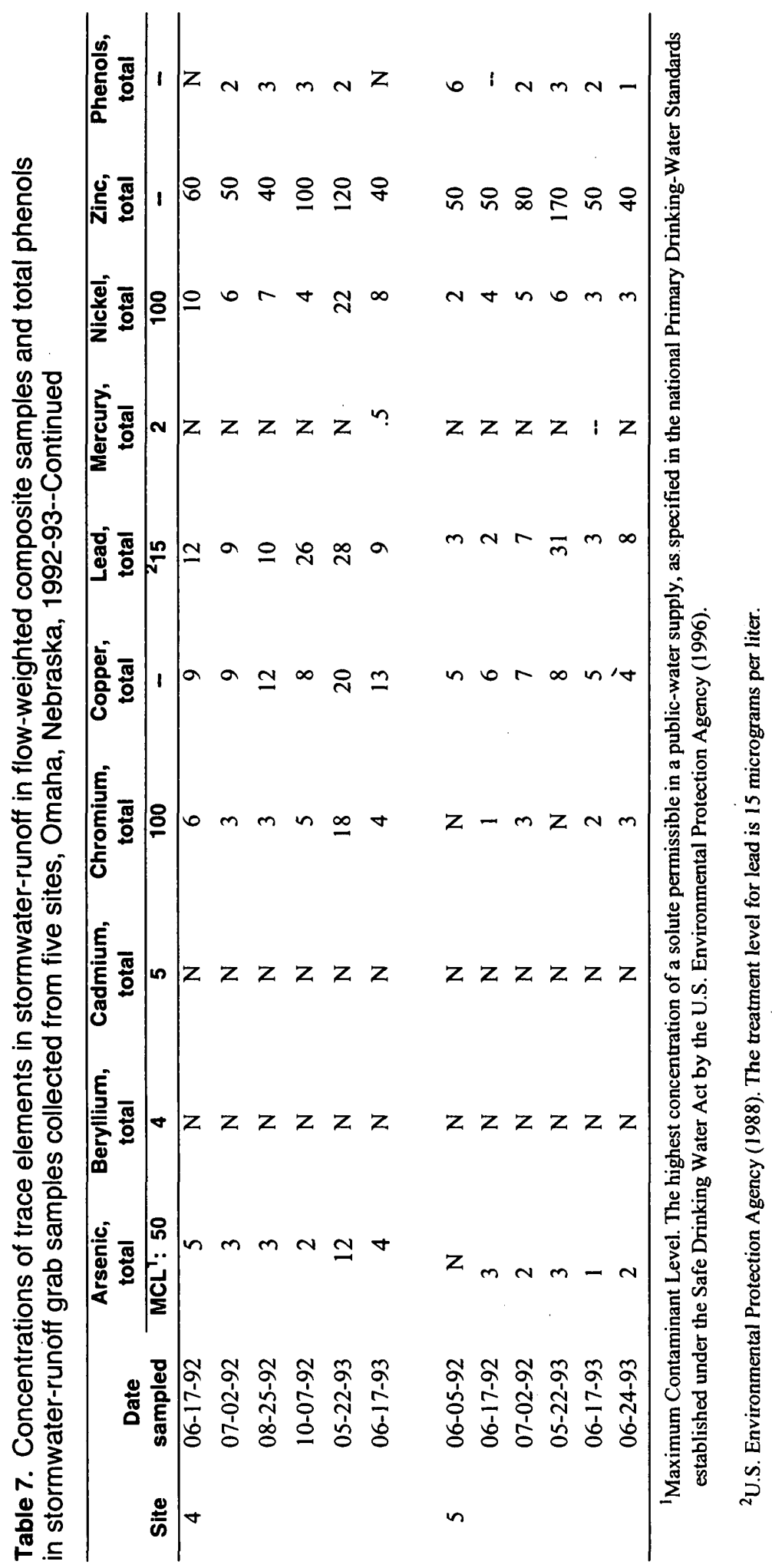

B-12 Quantity and Quality of Urban Stormwater Runoff from Selected Drainage Basins, Omaha, Nebraska, 1992-93 


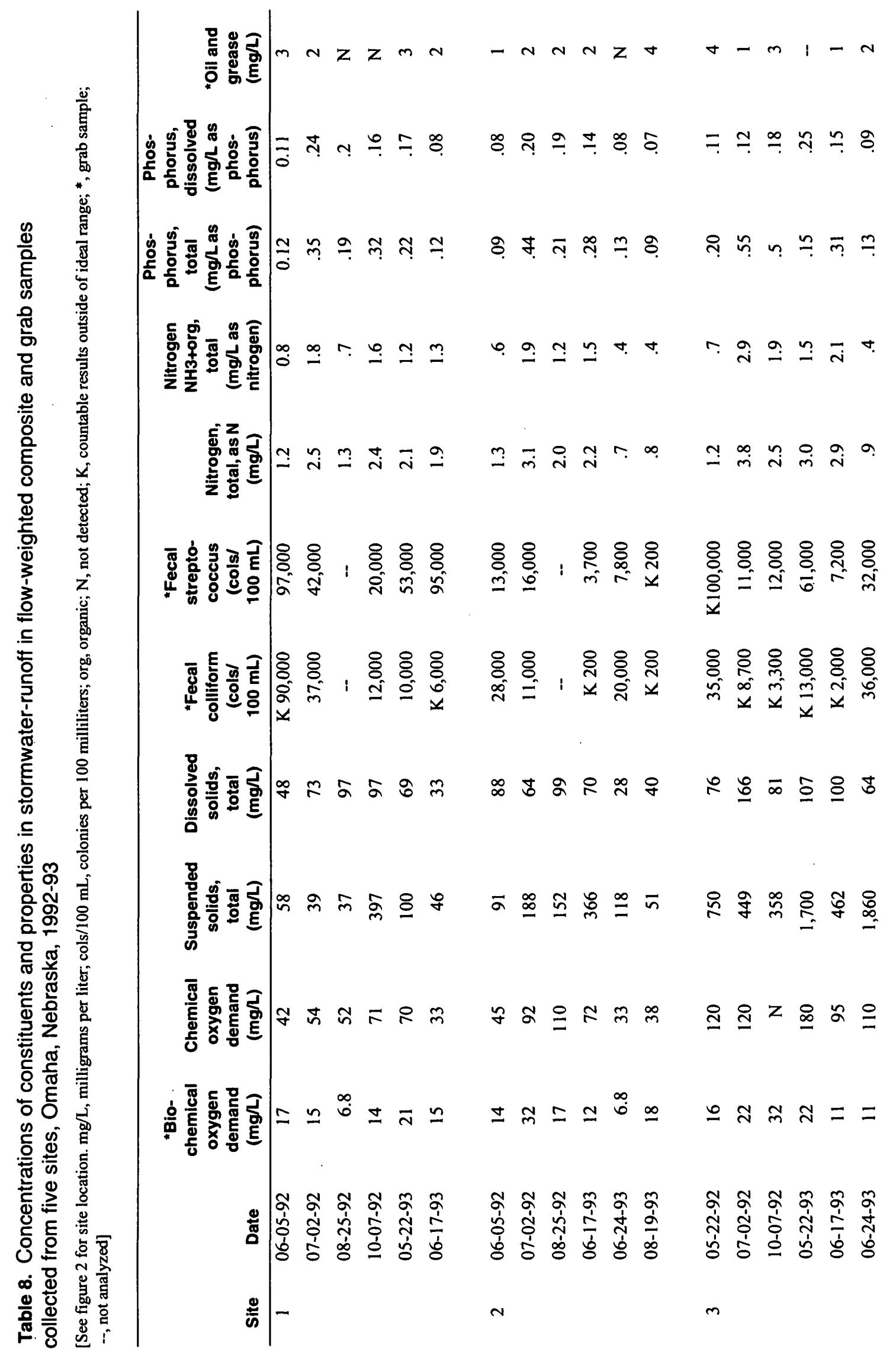




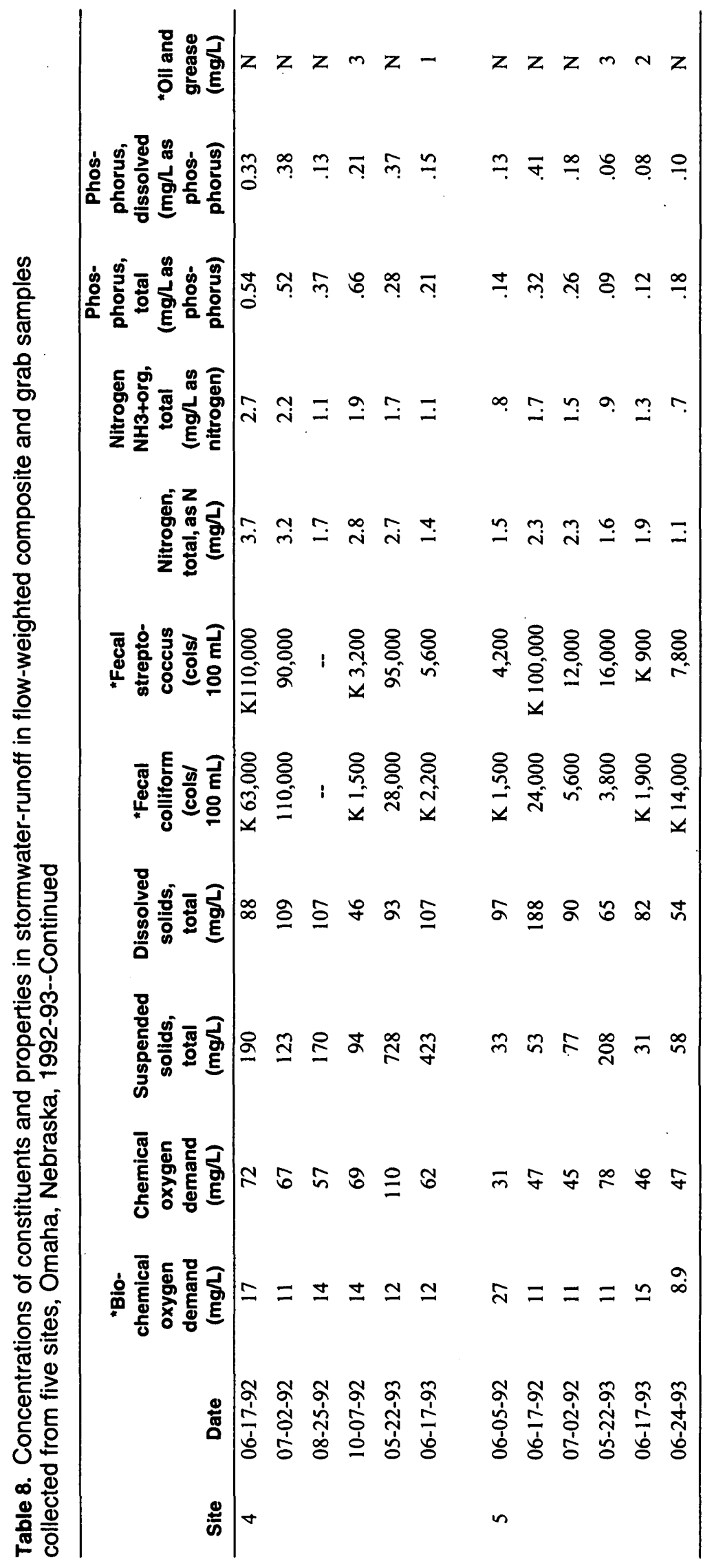

B-14 Quantity and Quality of Urban Stormwater Runoff from Selected Drainage Basins, Omaha, Nebraska, 1992-93 


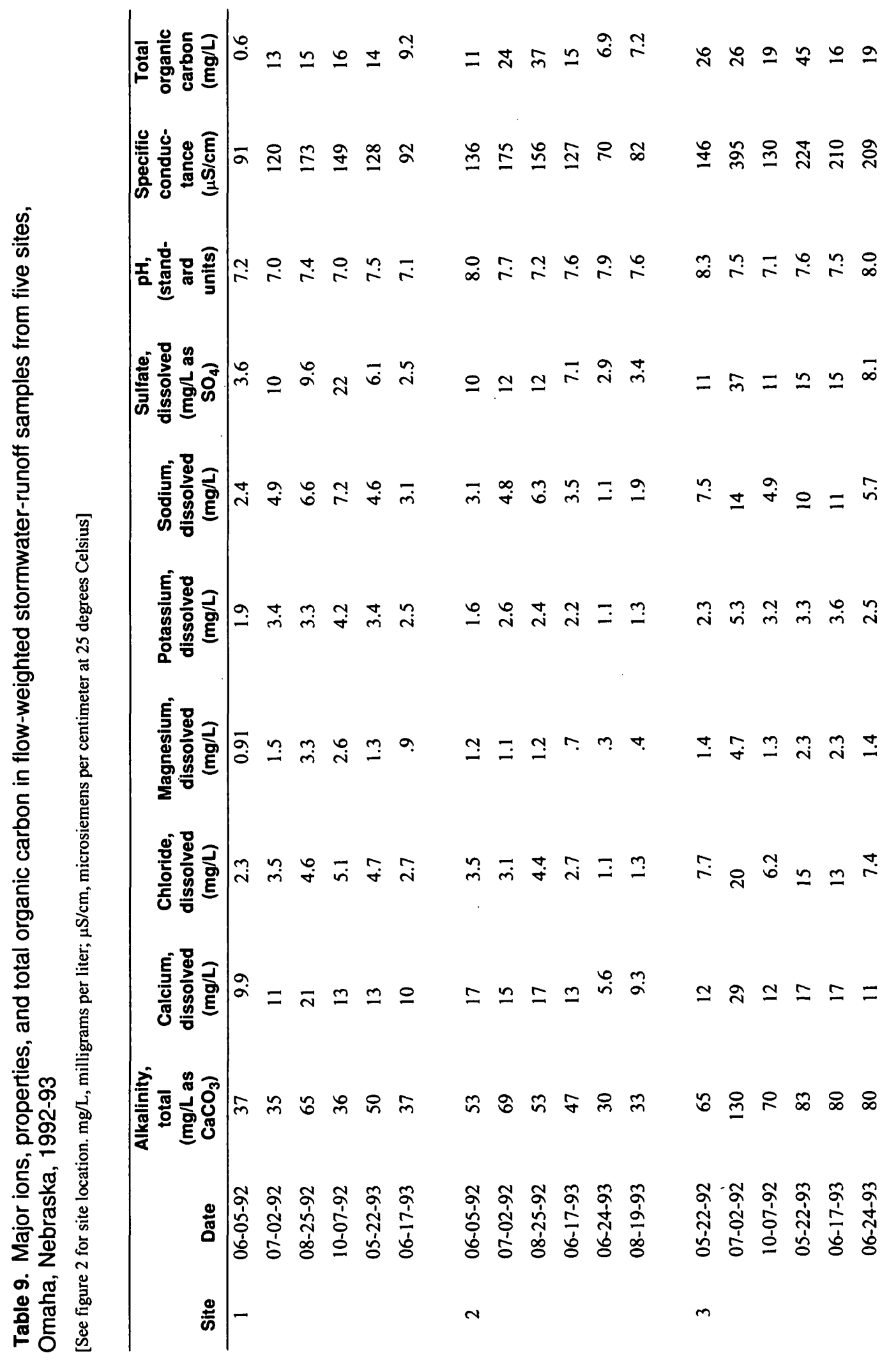




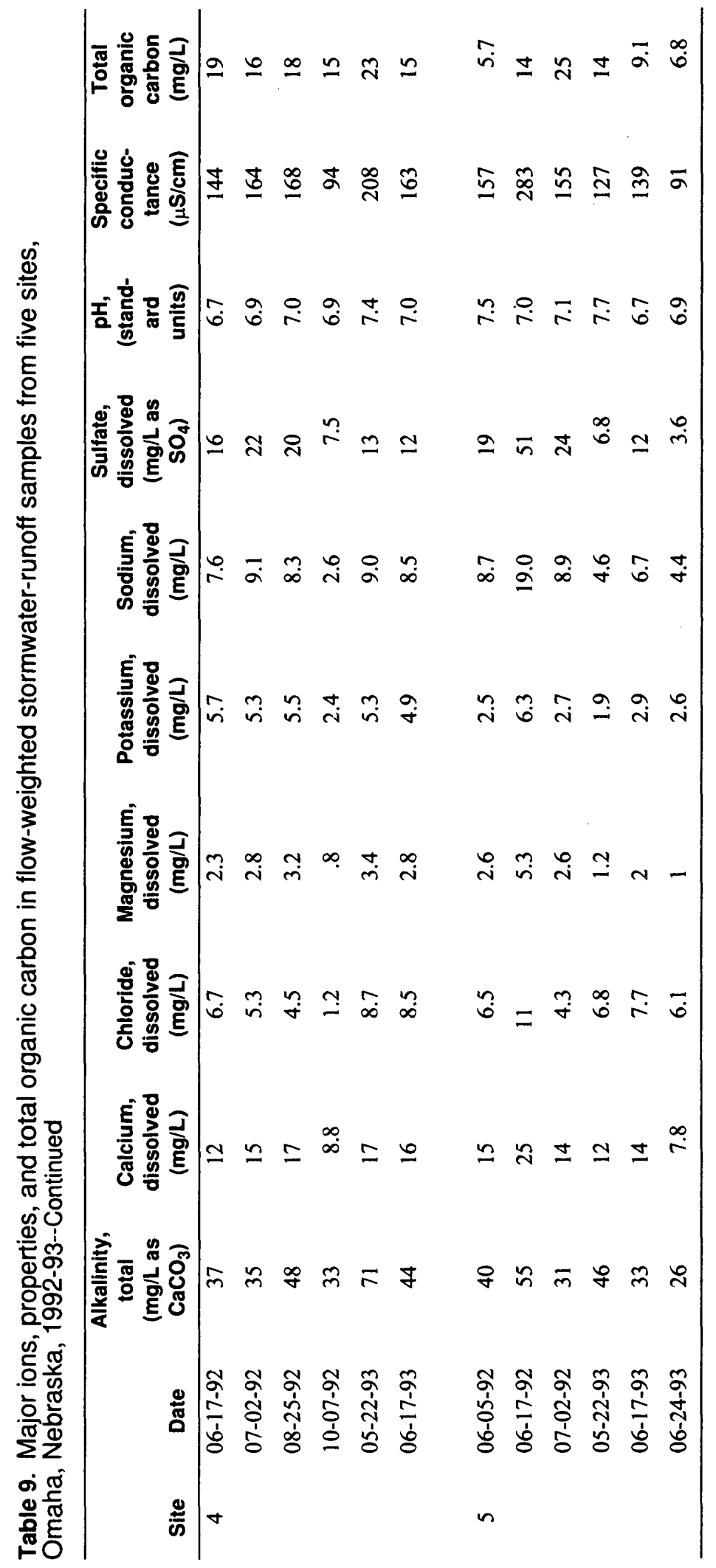

B-16 Quantity and Quality of Urban Stormwater Runoff from Selected Drainage Basins, Omaha, Nebraska, 1992-93 
APPENDIX C-QUALITY ASSURANCE INFORMATION SUMMARY 


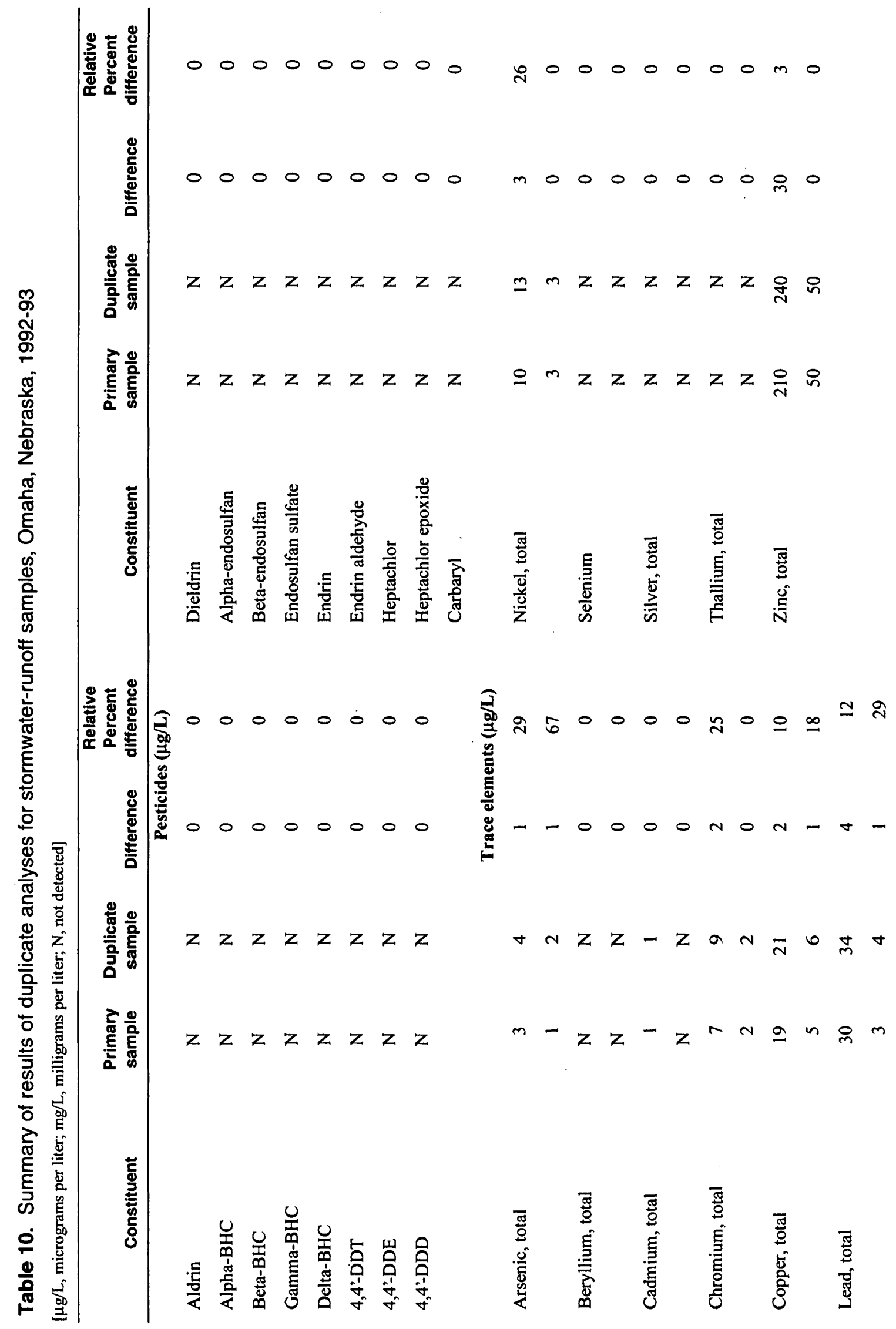




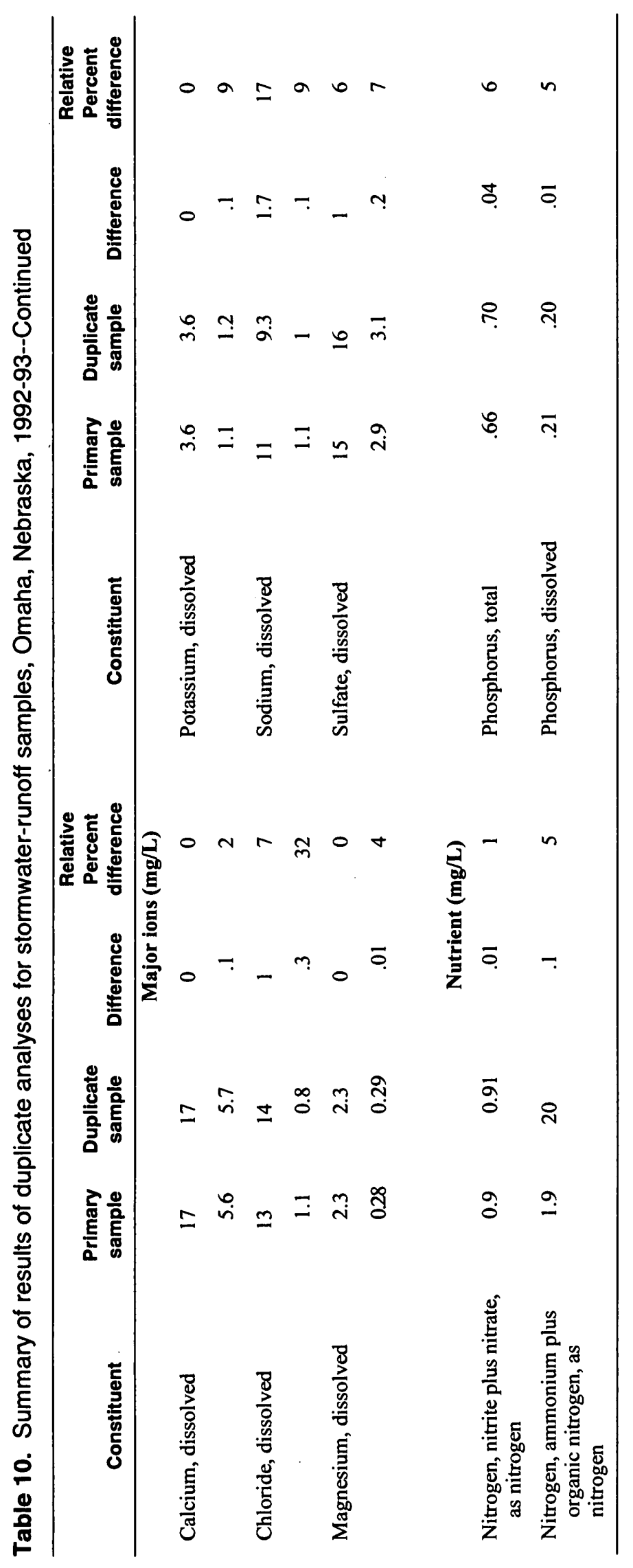


Table 11. Summary of results of field-blank analyses for stormwater-runoff samples, Omaha, Nebraska, 1992-93

[ $\mu \mathrm{g} / \mathrm{L}$, micrograms per liter; mg/L, milligrams per liter; $\mathrm{N}$, not detected]

\begin{tabular}{|c|c|c|c|c|c|}
\hline Constituent & $\begin{array}{l}\text { Primary } \\
\text { sample }\end{array}$ & $\begin{array}{l}\text { Field blank } \\
\text { sample }\end{array}$ & Constituent & $\begin{array}{l}\text { Primary } \\
\text { sample }\end{array}$ & $\begin{array}{c}\text { Fleld } \\
\text { blank } \\
\text { sample }\end{array}$ \\
\hline \multicolumn{6}{|c|}{ Volatile organic compounds $(\mu \mathrm{g} / \mathrm{L})$} \\
\hline \multirow[t]{3}{*}{ Benzene, total } & $\mathrm{N}$ & $\mathrm{N}$ & 1,2-Dichloropropane & $\mathrm{N}$ & $\mathbf{N}$ \\
\hline & $\mathrm{N}$ & $\mathbf{N}$ & & $\mathbf{N}$ & $\mathbf{N}$ \\
\hline & $\mathrm{N}$ & $\mathbf{N}$ & & $\mathrm{N}$ & $\mathbf{N}$ \\
\hline \multirow[t]{3}{*}{ Bromoform, total } & $\mathrm{N}$ & $\mathrm{N}$ & Ethylbenzene & $\mathrm{N}$ & $\mathrm{N}$ \\
\hline & $\mathrm{N}$ & $\mathbf{N}$ & & $\mathrm{N}$ & $\mathbf{N}$ \\
\hline & $\mathrm{N}$ & $\mathbf{N}$ & & $\mathrm{N}$ & $\mathrm{N}$ \\
\hline \multirow{3}{*}{$\begin{array}{l}\text { Carbon tetrachloride, } \\
\text { total }\end{array}$} & $\mathrm{N}$ & $\mathrm{N}$ & Methylene chloride & $\mathrm{N}$ & 1.2 \\
\hline & $\mathrm{N}$ & $\mathbf{N}$ & & $\mathbf{N}$ & .9 \\
\hline & $\mathrm{N}$ & $\mathbf{N}$ & & $\mathbf{N}$ & .8 \\
\hline \multirow[t]{3}{*}{ Chlorobenzene } & $\mathrm{N}$ & $\mathrm{N}$ & $1,1,2,2$-Tetrachloroethane & $\mathrm{N}$ & $\mathrm{N}$ \\
\hline & $\mathbf{N}$ & $\mathbf{N}$ & & $\mathrm{N}$ & $\mathrm{N}$ \\
\hline & $\mathrm{N}$ & $\mathbf{N}$ & & $\mathrm{N}$ & $\mathbf{N}$ \\
\hline \multirow[t]{3}{*}{ Chloroethane } & $\mathrm{N}$ & $\mathrm{N}$ & Tetrachloroethylene & $\mathrm{N}$ & $\mathrm{N}$ \\
\hline & $\mathrm{N}$ & $\mathbf{N}$ & & $\mathrm{N}$ & $\mathrm{N}$ \\
\hline & $\mathbf{N}$ & $\mathrm{N}$ & & $\mathbf{N}$ & $\mathrm{N}$ \\
\hline \multirow{3}{*}{$\begin{array}{l}\text { 2-Chloroethylvinyl } \\
\text { ether }\end{array}$} & $\mathrm{N}$ & $\mathrm{N}$ & Toluene & 0.2 & $\mathbf{N}$ \\
\hline & $\mathrm{N}$ & $\mathrm{N}$ & & $\mathrm{N}$ & $\mathrm{N}$ \\
\hline & $\mathrm{N}$ & $\mathrm{N}$ & & $\mathrm{N}$ & $\mathrm{N}$ \\
\hline \multirow[t]{3}{*}{ Chloroform } & $\mathrm{N}$ & $\mathbf{N}$ & 1,1,1-Trichloroethane & $\mathbf{N}$ & $\mathrm{N}$ \\
\hline & $\mathrm{N}$ & $\mathrm{N}$ & & $\mathrm{N}$ & $\mathrm{N}$ \\
\hline & $\mathrm{N}$ & $\mathrm{N}$ & & $\mathrm{N}$ & $\mathrm{N}$ \\
\hline \multirow[t]{3}{*}{ Dichlorobromomethane } & $\mathrm{N}$ & $\mathbf{N}$ & 1, 1, 2-Trichloroethane & $\mathbf{N}$ & $\mathrm{N}$ \\
\hline & $\mathrm{N}$ & $\mathrm{N}$ & & $\mathrm{N}$ & $\mathrm{N}$ \\
\hline & $\mathrm{N}$ & $\mathrm{N}$ & & $\mathrm{N}$ & $\mathrm{N}$ \\
\hline \multirow[t]{3}{*}{ 1,1-Dichloroethane } & $\mathrm{N}$ & $\mathbf{N}$ & Trichloroethylene & $\mathrm{N}$ & $\mathrm{N}$ \\
\hline & $\mathrm{N}$ & $\mathrm{N}$ & & $\mathrm{N}$ & $\mathrm{N}$ \\
\hline & $\mathrm{N}$ & $\mathrm{N}$ & & $\mathrm{N}$ & $\mathrm{N}$ \\
\hline \multirow[t]{3}{*}{ 1,2-Dichloroethane } & $\mathrm{N}$ & $\mathrm{N}$ & Vinyl chloride & $\mathrm{N}$ & $\mathrm{N}$ \\
\hline & $\mathrm{N}$ & $\mathrm{N}$ & & $\mathbf{N}$ & $\mathrm{N}$ \\
\hline & $\mathbf{N}$ & $\mathrm{N}$ & & $\mathbf{N}$ & $\mathbf{N}$ \\
\hline \multirow[t]{3}{*}{ 1,1-Dichloroethylene } & $\mathrm{N}$ & $\mathrm{N}$ & & $\mathrm{N}$ & $\mathrm{N}$ \\
\hline & $\mathrm{N}$ & $\mathrm{N}$ & & $\mathrm{N}$ & $\mathrm{N}$ \\
\hline & $\mathrm{N}$ & $\mathrm{N}$ & & $\mathrm{N}$ & $\mathrm{N}$ \\
\hline \multicolumn{6}{|c|}{ Pesticide $(\mu \mathrm{g} / \mathrm{L})$} \\
\hline Carbaryl & $\mathbf{N}$ & $\mathrm{N}$ & & & \\
\hline
\end{tabular}


Table 11. Summary of results of field-blank analyses for stormwater-runoff samples, Omaha, Nebraska, 1992-93--Continued

\begin{tabular}{|c|c|c|c|c|c|}
\hline Constituent & $\begin{array}{l}\text { Primary } \\
\text { sample }\end{array}$ & $\begin{array}{l}\text { Field blank } \\
\text { sample }\end{array}$ & Constituent & $\begin{array}{l}\text { Primary } \\
\text { sample }\end{array}$ & $\begin{array}{l}\text { Field } \\
\text { blank } \\
\text { sample }\end{array}$ \\
\hline \multicolumn{6}{|c|}{ Trace elements $(\mu \mathrm{g} / \mathrm{L})$} \\
\hline Arsenic, total & 11 & 2 & Nickel, total & 14 & $\mathrm{~N}$ \\
\hline Beryllium, total & $\mathrm{N}$ & $\mathrm{N}$ & Selenium & $\mathrm{N}$ & $\mathrm{N}$ \\
\hline Cadmium, total & $\mathrm{N}$ & $\mathrm{N}$ & Silver, total & $\mathrm{N}$ & $\mathrm{N}$ \\
\hline Chromium, total & 8 & $\mathrm{~N}$ & Thallium, total & $\mathrm{N}$ & $\mathrm{N}$ \\
\hline Copper, total & 9 & $\mathrm{~N}$ & Zinc, total & 100 & $\mathrm{~N}$ \\
\hline Lead, total & 18 & 2 & & & \\
\hline \multicolumn{6}{|c|}{ Major ions (mg/L) } \\
\hline Calcium, dissolved & 13 & 1.1 & Potassium, dissolved & 4.2 & 0.2 \\
\hline Chloride, dissolved & 5.1 & .2 & Sodium, dissolved & 7.2 & 1.5 \\
\hline Magnesium, dissolved & 2.6 & .14 & Sulfate, dissolved & 22 & .3 \\
\hline \multicolumn{6}{|c|}{ Nutrient $(\mathrm{mg} / \mathrm{L})$} \\
\hline $\begin{array}{l}\text { Nitrogen, nitrite plus } \\
\text { nitrate, as nitrogen }\end{array}$ & .79 & $\mathrm{~N}$ & Phosphorus, total & .32 & .01 \\
\hline $\begin{array}{l}\text { Nitrogen, ammonium } \\
\text { plus oranic nitrogen, } \\
\text { as nitrogen }\end{array}$ & 1.6 & $\mathrm{~N}$ & Phosphorus, dissolved & .16 & .02 \\
\hline
\end{tabular}


Table 12. Summary of results of field-spike analyses for stormwater-runoff samples,

Omaha, Nebraska, 1992-93

$[\mu \mathrm{g} / \mathrm{L}$, micrograms per liter]

\begin{tabular}{|c|c|c|c|c|c|}
\hline Constituent & $\begin{array}{c}\text { Sample } \\
\text { fortification } \\
\text { concentrations }\end{array}$ & $\begin{array}{c}\text { First Field } \\
\text { spike sample } \\
(08-28-92)\end{array}$ & $\begin{array}{c}\text { Recovery } \\
\text { percent }\end{array}$ & $\begin{array}{c}\text { Second Field } \\
\text { spike sample } \\
(06-17-93)\end{array}$ & $\begin{array}{c}\text { Recovery } \\
\text { percent }\end{array}$ \\
\hline \multicolumn{6}{|c|}{ Acid organic compounds $(\mu \mathrm{g} / \mathrm{L})$} \\
\hline 2-Chlorophenol & 50 & 32 & 64 & 34 & 68 \\
\hline 2,4-Dichlorophenol & 50 & 17 & 34 & 42 & 84 \\
\hline 2,4-Dimethylphenol & 50 & 11 & 22 & 45 & 90 \\
\hline 2-Nitrophenol & 50 & 39 & 78 & 50 & 100 \\
\hline 4-Nitrophenol & 250 & 150 & 60 & 130 & 52 \\
\hline Pentachlorophenol & 250 & 230 & 92 & 200 & 80 \\
\hline Phenol & 50 & $<5$ & 0 & $<5$ & 0 \\
\hline 2,4,6-Trichlorophenol & 150 & 130 & 87 & 160 & 107 \\
\hline
\end{tabular}

Base/neutral organic compounds $(\mu \mathrm{g} / \mathrm{L})$

\begin{tabular}{|c|c|c|c|c|c|}
\hline Acenaphthalene & 20 & 12 & 60 & 12 & 60 \\
\hline Acenaphthene & 20 & 13 & 65 & 15 & 75 \\
\hline Anthracene & 20 & 13 & 65 & 14 & 70 \\
\hline Benzo-A-anthracene & 20 & 15 & 75 & 17 & 85 \\
\hline Benzo-A-pyrene & 20 & 13 & 65 & 14 & 70 \\
\hline 3,4-Benzofluoranthene & 20 & 16 & 80 & 18 & 90 \\
\hline 2,4-Benzo(ghi)perylëne & 20 & 11 & 55 & 14 & 70 \\
\hline Benzo(k)fluoranthene & 20 & 16 & 80 & 16 & 80 \\
\hline Bis (2-Chloroethoxy) methane & 20 & 15 & 75 & 16 & 80 \\
\hline Bis (2-Chloroethyl) ether & 20 & 15 & 75 & 15 & 75 \\
\hline Bis (2-Chloroisopropyl) ether & 20 & 12 & 60 & 14 & 70 \\
\hline Bis (2-ethylhexyl) phthalate & 20 & 21 & 105 & 24 & 120 \\
\hline Butylbenzyl phthalate & 20 & 10 & 50 & 12 & 60 \\
\hline 2-Chloronaphthalene & 20 & 14 & 70 & 13 & 65 \\
\hline 4-Chlorophenyl phenyl ether & 20 & 15 & 75 & 15 & 75 \\
\hline Chrysene & 20 & 16 & 80 & 16 & 80 \\
\hline Dibenzo $(A, H)$ anthracene & 20 & 11 & 55 & 13 & 65 \\
\hline 1,2-Dichlorobenzene & 20 & 11 & 55 & 13 & 65 \\
\hline 1,3-Dichlorobenzene & 20 & 10 & 50 & 13 & 65 \\
\hline 1,4-Dichlorobenzene & 20 & 10 & 50 & 13 & 65 \\
\hline 3,3-Dichlorobenzidine & 20 & $<20$ & 0 & $<20$ & 0 \\
\hline Diethyl phthalate & 20 & 14 & 70 & 17 & 85 \\
\hline Dimethyl phthalate & 20 & 13 & 65 & 15 & 75 \\
\hline Di-N-butyl phthalate & 20 & 11 & 55 & 10 & 50 \\
\hline 2,4-Dinitrotoluene & 20 & 7 & 35 & 23 & 115 \\
\hline 2,6-Dinitrotoluene & 20 & 16 & 80 & 23 & 115 \\
\hline Di-N-octyl phthlate & 20 & 29 & 145 & 23 & 115 \\
\hline
\end{tabular}


Table 12. Summary of results of field spike analyses for stormwater-runoff samples, Omaha, Nebraska, 1992-93--Continued

\begin{tabular}{|c|c|c|c|c|c|}
\hline Constituent & $\begin{array}{c}\text { Sample } \\
\text { fortification } \\
\text { concentrations }\end{array}$ & $\begin{array}{l}\text { First Fleld } \\
\text { splke sample } \\
(08-28-92)\end{array}$ & $\begin{array}{c}\text { Recovery } \\
\text { percent }\end{array}$ & $\begin{array}{c}\text { Second Field } \\
\text { spike sample } \\
(06-17-93)\end{array}$ & $\begin{array}{c}\text { Recovery } \\
\text { percent }\end{array}$ \\
\hline \multicolumn{6}{|c|}{ Base/neutral organic compounds $(\mu \mathrm{g} / \mathrm{L})$-Continued } \\
\hline Fluoranthene & 20 & 18 & 90 & 13 & 65 \\
\hline Fluorene & 20 & 12 & 60 & $<5$ & 0 \\
\hline Hexachlorocyclopentadiene & 20 & $<5$ & 0 & $<5$ & 0 \\
\hline Hexachloroethane & 20 & 8 & 40 & $<5$ & 0 \\
\hline Indeno $(1,2,3-C D)$ pyrene & 20 & 12 & 60 & $<5$ & 0 \\
\hline Isophorone & 20 & 6 & 30 & $<5$ & 0 \\
\hline Napthalene & 20 & 13 & 65 & 8 & 40 \\
\hline Nitrobenzene & 20 & 16 & 80 & 17 & 85 \\
\hline N-Nitrosodimethylamine & 20 & 11 & 55 & $<5$ & 0 \\
\hline N-Nitrosodi-N-propylamine & 20 & 14 & 70 & $<5$ & 0 \\
\hline N-Nitrosodiphenylamine & 20 & 8 & 40 & $<5$ & 0 \\
\hline Phenanthrene & 20 & 9 & 45 & $<5$ & 0 \\
\hline Pyrene & 20 & 16 & 80 & 18 & 90 \\
\hline \multicolumn{6}{|c|}{ Pesticides $(\mu \mathrm{g} / \mathrm{L})$} \\
\hline Aldrin & 1 & .70 & 70 & .89 & 89 \\
\hline Alpha-BHC & 1 & .92 & 92 & .73 & 73 \\
\hline Beta-BHC & 1 & 2.0 & 200 & 1.9 & 190 \\
\hline Gamma-BHC & 1 & .93 & 93 & .83 & 83 \\
\hline Delta-BHC & 1 & 2.3 & 230 & 2.2 & 220 \\
\hline 4,4'-DDT & 6 & 5.2 & 87 & 5.2 & 87 \\
\hline 4,4'-DDE & 2 & 1.9 & 95 & 1.8 & 90 \\
\hline 4,4'-DDD & 6 & 5.1 & 85 & 5.0 & 83 \\
\hline Dieldrin & 2 & 4.8 & 240 & 4.5 & 225 \\
\hline Alpha-endosulfan & 2 & 3.4 & 170 & 3.6 & 180 \\
\hline Beta-endosulfan & 2 & 4.0 & 200 & 3.1 & 155 \\
\hline Endosulfan sulfate & 6 & 13 & 217 & 12 & 200 \\
\hline Endrin & 2 & 4.7 & 235 & 4.2 & 210 \\
\hline Endrin aldehyde & 6 & .80 & 13 & .9 & 15 \\
\hline Heptachlor & 1 & 1.0 & 100 & .94 & 94 \\
\hline Heptachlor epoxide & 1 & 1.7 & 170 & 1.7 & 170 \\
\hline
\end{tabular}

